INSTITUTO DE PESQUISAS ENERGÉTICAS E NUCLEARES

Autarquia associada à Universidade de São Paulo

DIRETRIZES PARA IMPLANTAÇÃO DE UM SISTEMA DE GESTÃO AMBIENTAL NO CICLO DO COMBUSTÍVEL NUCLEAR: ESTUDO DE CASO

DA USEXA - CEA

SANDRA REGINA MATTIOLO

Tese apresentada como parte dos requisitos para a obtenção do grau de Doutor em Ciências na Área de Tecnologia Nuclear - Materiais

Orientador:

Prof. Dr. Afonso Rodrigues de Aquino

São Paulo 


\section{DEDICATÓRIA}

Dedico este trabalho aos meus pais Tereza e Milton que por meio de seus exemplos sempre incentivaram meu crescimento pessoal e profissional

À minha filha Isabella pelo seu amor e apoio Aos meus irmãos Fátima, Amilton e a irmã do coração Vera. 


\section{AGRADECIMENTOS}

Agradeço a Deus pela oportunidade desta reencarnação, aprendizado e evolução.

Agradeço:

Ao Dr. Othon Luiz Pinheiro da Silva pela oportunidade de ingressar no meio acadêmico.

Ao Prof. Dr. Afonso Rodrigues de Aquino, pela orientação, incentivo e especialmente amizade.

À Direção do Centro Tecnológico da Marinha em São Paulo (CTMSP), pela permissão de desenvolver esta pesquisa.

Ao Marco Antonio Calixto Pádua e Dirceu Paulo de Oliveira pelo incentivo, apoio e amizade.

Aos funcionários da USEXA na pessoa do Comte. André Luis Ferreira Marques.

Ao Paulo Eduardo Vicente Dias, Encarregado do Departamento de Operação da USEXA pelas contribuições valiosas a este trabalho.

Ao Instituto de Pesquisas Energéticas e Nucleares, em particular aos funcionários da Comissão de Pós-Graduação do IPEN.

À Prof. Dra Martha Marques Ferreira Vieira, pelas valiosas contribuições.

À turma da disciplina TNM 5790 - Análise de Sistemas de Gestão Ambiental de 2008, pelas experiências trocadas e pelos momentos agradáveis que vivenciamos, em especial: Nayara dos Santos Egute, Tereza Cristina Salvetti, Lílian de Oliveira Bueno, Rosane Napolitano Raduan, Juliana Ikebe Otomo e Marcelo Paranzini.

À amiga Thabiani Cristine Aradi pela ajuda e comentários.

Aos amigos Cézar Braga Alves, Larissa Sartório Bayer, José Roberto Camargo e Cléber de Souza Cordovil pela colaboração e incentivo, e a todos que de alguma forma contribuíram para o desenvolvimento deste trabalho. 
(...) quis fugir, mas, ao mesmo tempo, disse a mim mesma: - Não! É preciso chegar até o fim para saber as forças que tem minha alma. 


\title{
DIRETRIZES PARA IMPLANTAÇÃO DE UM SISTEMA DE GESTÃO AMBIENTAL NO CICLO DO COMBUSTÍVEL NUCLEAR: ESTUDO DE CASO DA USEXA - CEA
}

\author{
Sandra Regina Mattiolo
}

\begin{abstract}
RESUMO
As normas de gestão ambiental têm por objetivo prover as organizações dos elementos necessários para implantação de Sistemas da Gestão Ambiental (SGA) que possam ser integrados a outros requisitos da gestão, e auxiliá-las a alcançar seus objetivos ambientais e econômicos. A Unidade de Produção de Hexafluoreto de Urânio - USEXA, do Centro Tecnológico da Marinha em São Paulo - CTMSP, será a primeira planta industrial da etapa de conversão do ciclo do combustível nuclear (produção de hexafluoreto de urânio - $U F_{6}$ ) do Brasil, permitindo que seja agregado valor ao minério de urânio. Neste trabalho, o SGA proposto para a USEXA, permite disciplinar suas interfaces com o meio ambiente, uma vez que as Normas da CNEN - Comissão Nacional de Energia Nuclear e da AIEA - Agência Internacional de Energia Atômica para instalações nucleares, na sua grande maioria, visam a atender a critérios de segurança para o público e o meio ambiente, apenas nos quesitos envolvendo radiações ionizantes. O modelo de SGA desenvolvido preenche as lacunas das normas da CNEN e da AIEA, por considerar os impactos ambientais decorrentes do uso de substâncias químicas no processo de fabricação de $\mathrm{UF}_{6} \mathrm{e}$ os aspectos gerais de sustentabilidade. Isso pode ser considerado uma contribuição original dentro das complexas atividades que abrangem o processamento de urânio no ciclo do combustível nuclear. Como resultado, esta pesquisa propõe, para avaliação de impactos ambientais, a adoção de um filtro de significância, relacionado à localização do empreendimento, apresenta um Manual do Sistema de Gestão para a USEXA e sugere modelos de treinamentos em gestão de pessoal, como o coaching e a programação neurolinguística, e que poderão ser aplicados em qualquer Sistema de Gestão. Os treinamentos podem ser considerados como uma ação preventiva, por contribuírem para diminuir os incidentes relacionados à manutenção de equipamentos e consequentemente a ocorrência de impactos ambientais.
\end{abstract}




\title{
GUIDELINES FOR IMPLEMENTATION OF AN ENVIRONMENTAL MANAGEMENT SYSTEM IN THE NUCLEAR FUEL CYCLE: A CASE STUDY OF USEXA-CEA
}

\author{
Sandra Regina Mattiolo
}

\begin{abstract}
The environmental management standards are intended to provide to the organizations the elements needed for the implementation of an Environmental Management System (EMS) that can be effectively integrated to another management requirements and assist them to achieve their environmental and economic goals. The Uranium Hexafluoride Production Unit - USEXA, located at the Navy Technological Center in São Paulo, will be the first Brazilian industrial plant responsible for the conversion stage in the nuclear fuel cycle (production of uranium hexafluoride - UF6), allowing added-value to the uranium ore. The EMS proposed to USEXA in this project allows to regulate its interfaces with the environment, since the Standards of CNEN - National Commission of Nuclear Energy and of the IAEA - International Atomic Energy Agency for Nuclear Installations, aim, mostly, to attend the security criteria for the population and the environment, concerning ionizing radiation. This model of EMS fills the gaps in standards of IAEA and CNEN, since it takes into account the environmental impacts from the use of chemicals in the manufacturing process of UF6, and general aspects of sustainability. It can be considered an original contribution within the complex activities that includes the uranium processing in the nuclear fuel cycle. This research proposes, as result, the use of a filter of significance to evaluate the environmental impacts depending on the installation location. It is also presented the Management System Manual for USEXA and models for training in personnel management are suggested, such as coaching and neurolinguistic programing, which can be applied to any Management System. The trainings can be considered a preventive action as they considerably decreased incidents related to equipment's maintenance and thus the occurrence of environmental impacts.
\end{abstract}




\section{SUMÁRIO}

Página

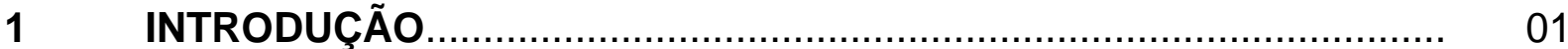

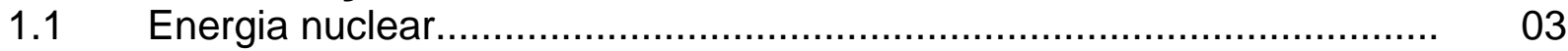

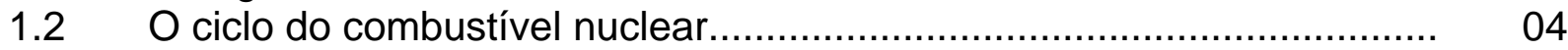

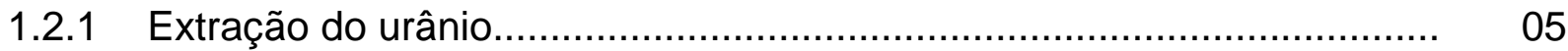

1.2.2 Purificação do urânio................................................................ 07

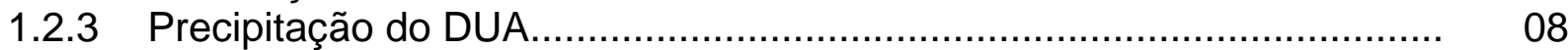

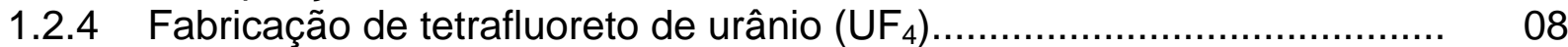

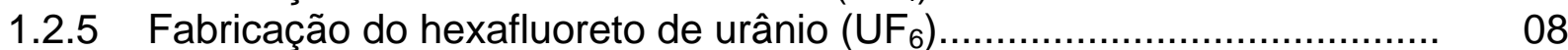

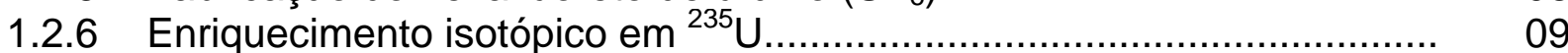

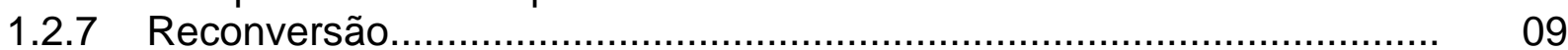

1.3 Programa Nuclear Brasileiro (PNB) e Programa Nuclear da Marinha (PNM).

1.4 Centro Tecnológico da Marinha em São Paulo - CTMSP ..................... 12

1.5 Sistema de Gestão Ambiental...................................................... 16

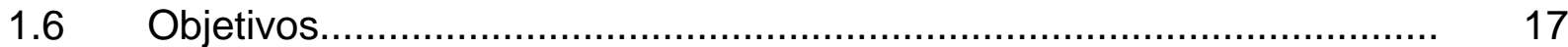

$1.7 \quad$ Justificativa para o desenvolvimento do trabalho................................ 17

2 DESENVOLVIMENTO TEÓRICO E COLETA DE DADOS ................... 19

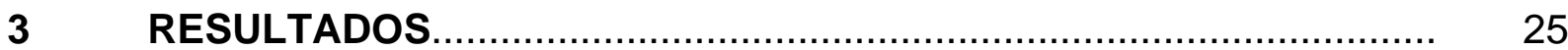

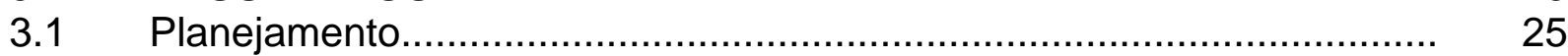

3.1.1 Política ambiental.......................................................... 25

3.1.2 Auditoria prognóstica - aspectos e impactos ambientais........... 25

3.1.3 Requisitos legais............................................................ 40

3.1.4 Avaliação dos impactos ambientais....................................... 40

3.1.5 Objetivos, metas e programas............................................. 49

3.1.6 Plano de Ação..................................................................... 50

3.1.7 Programas específicos...................................................... 54

Implementação e Operação......................................................... 54

3.2.1 Funções, responsabilidades e autoridades............................ 54

3.2.2 Competência, treinamento e conscientização........................ 55

3.2.3 Comunicação............................................................ 71

3.2.4 Documentação do SGA.................................................

3.2.5 Controle de documentos e registros...................................... 92

3.2.6 Preparação e resposta à emergência...................................... 92

3.3 Verificação................................................................................. 92

3.3.1 Monitoramento e medição.................................................... $\quad 92$

3.3.2 Avaliação do atendimento a requisitos legais e outros................ 93

3.3.3 Não conformidade, ação corretiva e ação preventiva.................. 94

3.3.4 Indicadores de desempenho.......................................... 94

3.3.5 Auditoria interna e análise pela administração........................ 95

3.3.6 Processo de acreditação.................................................... 95

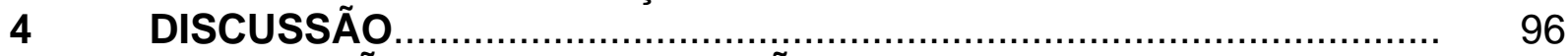

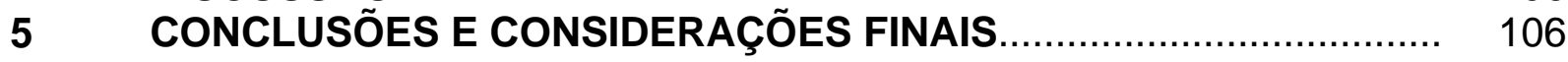

$6 \quad$ TRABALHOS FUTUROS ........................................................ 107

APENDICE A - NORMAS E LEGISLAÇOES APLICAVEIS AS ATIVIDADES

APÊNDICE B - DIRETRIZES PARA TREINAMENTO E CONSCIENTIZAÇÃ̃o APÊNDICE C - MANUAL DE GESTÃO AMBIENTAL. 


\section{LISTA DE TABELAS}

Página

TABELA 1 - Teores máximos permissíveis de impurezas do urânio de "grau nuclear". 08

TABELA 2 - A Norma NBR ISO 14.001 e o ciclo PDCA............................... 24

TABELA 3 - Levantamento de aspectos e impactos - C10.11..................... 29

TABELA 4 - Levantamento de aspectos e impactos - C10.12....................... 30

TABELA 5 - Levantamento de aspectos e impactos - C10.13...................... 31

TABELA 6 - Levantamento de aspectos e impactos - C10.15 ..................... 32

TABELA 7 - Levantamento de aspectos e impactos - C10.21...................... 33

TABELA 8 - Levantamento de aspectos e impactos - C10.22 ................... 34

TABELA 9 - Levantamento de aspectos e impactos - C10.31.................... 35

TABELA 10 - Levantamento de aspectos e impactos - C10.32................... 36

TABELA 11 - Levantamento de aspectos e impactos - C10.41................... 37

TABELA 12 - Levantamento de aspectos e impactos - C10.42 ................... 38

TABELA 13 - Levantamento de aspectos e impactos - C10.43 .................... 39

TABELA 14 - Levantamento de aspectos e impactos - C10.51..................... 39

TABELA 15 - Objetivos, Metas e Programas propostos para USEXA.............. 51 


\section{LISTA DE FIGURAS}

Página

FIGURA 1 - Ciclo do Combustível Nuclear.................................................... 05

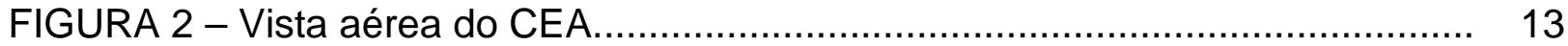

FIGURA 3 - Vista aérea da USEXA ........................................................ 15

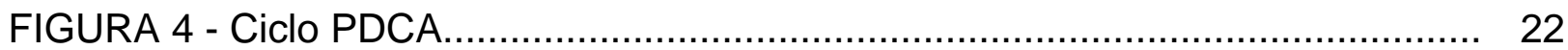

FIGURA 5 - Diagrama esquemático do processo de fabricação de UF 6 ....................... 26

FIGURA 6 - Diagrama de entrada e saída - Unidades que não estão diretamente envolvidas no processo de fabricação de $U_{6}$.

FIGURA 7 - Exemplo de Planilha de Avaliação de Impactos Ambientais no CEA....

FIGURA 8 - Exemplo de Planilha de Avaliação de Impactos Ambientais na Sede... 43

FIGURA 9 - Planilha de Avaliação de Impactos Ambientais da C10.11................ 44

FIGURA 10 - Planilha de Avaliação de Impactos Ambientais da C10.12............. 44

FIGURA 11 - Planilha de Avaliação de Impactos Ambientais da C10.13.............. 45

FIGURA 12 - Planilha de Avaliação de Impactos Ambientais da C10.15.............. 45

FIGURA 13 - Planilha de Avaliação de Impactos Ambientais da C10.21 e C10.23.. 46

FIGURA 14 - Planilha de Avaliação de Impactos Ambientais da C10.22............... 46

FIGURA 15 - Planilha de Avaliação de Impactos Ambientais da C10.31.............. 47

FIGURA 16 - Planilha de Avaliação de Impactos Ambientais da C10.32 .............. 47

FIGURA 17 - Planilha de Avaliação de Impactos Ambientais da C10.41.............. 47

FIGURA 18 - Planilha de Avaliação de Impactos Ambientais da C10.42.............. 48

FIGURA 19 - Planilha de Avaliação de Impactos Ambientais da C10.43............. 48

FIGURA 20 - Planilha de Avaliação de Impactos Ambientais comuns nas unidades 49

FIGURA 21 - Modelo de PGA proposto para a USEXA .................................... 53

FIGURA 22 - Organograma do CTMSP, com os destaques para as áreas 54 envolvidas neste trabalho. 


\section{LISTA DE SIGLAS}

ABNT Associação Brasileira de Normas Técnicas

ACP Ação corretiva

ADM Responsabilidade da administração

AIEA Agência Internacional de Energia Atômica

AUD Auditoria

CEA Centro Experimental Aramar

CEDIFAS Centro de Disposição Final da Fase Sólida

CETESB Companhia de Tecnologia de Saneamento Ambiental

CNEN Comissão Nacional de Energia Nuclear

CONAMA Conselho Nacional do Meio Ambiente

COPESP Coordenadoria para Projetos Especiais

CPR Controle de Processo

CTMSP Centro Tecnológico da Marinha em São Paulo

DBO Demanda bioquímica de oxigênio

DCoM Diretoria de Contas da Marinha

DGMM Diretoria Geral de Material da Marinha

DICOM Diretoria de Contas da Marinha

DPC Diretoria de Portos e Costas da Marinha do Brasil

DQO Demanda química de oxigênio

DUA Diuranato de amônio

EIA Estudo de Impacto Ambiental

EPI Equipamento de Proteção Individual

GEE Gases do Efeito Estufa

IAM Inspeção Administrativa da Marinha

IBAMA Instituto Brasileiro do Meio Ambiente e dos Recursos Naturais

Renováveis

ID

Instrução Detalhada

INB

Indústrias Nucleares do Brasil

IPEN Instituto de Pesquisas Energéticas e Nucleares

ISO International Organization for Standardization

LARE Laboratório Radioecológico 


\begin{tabular}{|c|c|}
\hline MW & Megawatt \\
\hline NBR & Norma Brasileira \\
\hline NCF & Não conformidade \\
\hline NORTAM & Norma Técnica Ambiental da Marinha do Brasil \\
\hline DPC & Diretoria de Portos e Costas \\
\hline USEXA & Unidade de Produção de Hexafluoreto de Urânio \\
\hline NUCLEP & Nuclebrás Equipamentos Pesados \\
\hline OM & Organização Militar \\
\hline PAT & Plano Anual de Treinamento \\
\hline PE & Plano de Emergência \\
\hline PEI & Plano de Emergência Individual - óleo \\
\hline PEL & Plano de Emergência Local \\
\hline PG & Programa \\
\hline PGA & Plano de Gestão Ambiental \\
\hline $\mathrm{pH}$ & potencial hidrogeniônico \\
\hline PMA & Plano de Monitoramento Ambiental \\
\hline PNB & Programa Nuclear Brasileiro \\
\hline PNL & Programação neurolinguistica \\
\hline PNM & Programa Nuclear da Marinha do Brasil \\
\hline PNUMA & Programa das Nações Unidas para o Meio Ambiente \\
\hline PR & Procedimento \\
\hline PRE & Preparação e respostas a emergência \\
\hline PWR & Pressurized water reactor \\
\hline REG & Registros \\
\hline RIMA & Relatório de Impacto Ambiental \\
\hline SGA & Sistema de Gestão Ambiental \\
\hline TER & Treinamento \\
\hline UNESCO & Organização das Nações Unidas para a Educação, a Ciência e a \\
\hline \multicolumn{2}{|l|}{ Cultura } \\
\hline UO & Unidade Organizacional \\
\hline
\end{tabular}




\section{INTRODUÇÃO}

A matriz energética pode ser entendida como o total de energia disponível para ser transformada, distribuída e consumida nos processos produtivos por um país ou uma região, além de atender às necessidades dos seus cidadãos.

Ao longo do tempo a matriz energética do Brasil foi sendo modificada e pode-se perceber uma clara tendência de diversificação da matriz energética brasileira. Em 1970 apenas duas fontes de energia, petróleo e carvão, respondiam por 78\% do consumo, ao passo que em 2000 três fontes correspondiam a 74\% do consumo: além de petróleo e carvão, a energia hidráulica. Projeta-se para 2030 uma situação em que quatro fontes serão necessárias para satisfazer $77 \%$ do consumo: além de petróleo e energia hidráulica, cana-de-açúcar e gás natural - com redução da importância relativa do carvão (TOLMASQUIM et al, 2007).

O Brasil possui a matriz energética mais renovável do mundo industrializado com $45,3 \%$ de sua produção proveniente de fontes como recursos hídricos, biomassa e etanol, além das energias eólica e solar. As usinas hidrelétricas são responsáveis pela geração de mais de $75 \%$ da eletricidade do país. Vale lembrar que a matriz energética mundial é composta por $13 \%$ de fontes renováveis, no caso de países industrializados, caindo para 6\% entre as nações em desenvolvimento. O Brasil possui uma matriz de energia elétrica que conta com a participação de $77,1 \%$ da hidroeletricidade. Energia proveniente de 140 usinas em operação, com perspectiva de aumento do uso dessa fonte. Ao longo dos últimos 30 anos, o país evitou a emissão de cerca de 800 milhões de toneladas de dióxido de carbono $\left(\mathrm{CO}_{2}\right)$ equivalente por meio do uso de etanol como substituto ou aditivo da gasolina. O Brasil usa energia hidrelétrica desde o final do século 19, mas foram as décadas de 1960 e 1970 que marcaram a fase de maior investimento na construção de grandes usinas. Por causa das opções feitas no passado, o país abriga hoje a maior hidrelétrica do mundo em geração de energia. Inaugurada em 1984 depois de um acordo binacional com o Paraguai, a Usina de Itaipu tem hoje potência instalada de 14 mil MW, com 20 unidades geradoras. Essa capacidade é suficiente para suprir cerca de $80 \%$ de toda a 
energia elétrica consumida no Paraguai e de $20 \%$ da demanda do sistema interligado brasileiro (PORTAL BRASIL, 2012).

TOLMASQUIM et al (2007), em um estudo sobre a prospectiva da matriz energética brasileira, avaliam que a participação da energia hidráulica na oferta de eletricidade, da ordem de 90\% em 2005, cairia para pouco mais de $70 \%$ em 2030. Já a geração térmica convencional (nuclear, a gás natural e a carvão mineral) expandiria sua participação dos atuais 7\% para cerca de 15\%. As fontes renováveis (ou não convencionais) não hidráulicas (biomassa da cana, centrais eólicas e resíduos urbanos) também deverão experimentar crescimento expressivo, passando a responder por mais de 4\% da oferta de eletricidade. Todas as formas de geração térmica irão se expandir mais de cinco vezes no período, aumentando o nível de emissões de gases na geração de energia elétrica. Essa é uma consequência natural de eventuais restrições ao desenvolvimento do potencial hidrelétrico brasileiro, não obstante a expansão que se possa admitir no parque gerador com base em outras fontes renováveis.

O Programa de Incentivo às Fontes Alternativas de Energia Elétrica PROINFA do Ministério de Minas e Energia - MME, conforme descrito no Decreto n 5.025 (BRASIL, 2004), foi instituído com o objetivo de aumentar a participação da energia elétrica produzida por empreendimentos concebidos com base em fontes eólicas, biomassa e Pequenas Centrais Hidrelétricas - PCH no Sistema Elétrico Interligado Nacional - SIN. O intuito é promover a diversificação da matriz energética brasileira, buscando alternativas para aumentar a segurança no abastecimento de energia elétrica, além de permitir a valorização das características e potencialidades regionais e locais (PROINFA, 2012).

O Brasil utiliza apenas um terço do seu potencial hídrico. Os projetos hídricos têm dificuldade de sair do papel devido, sobretudo, aos impasses socioambientais. Sem usinas de médio e grande porte planejadas, o país perde competitividade, pois a percepção de risco de abastecimento futuro se eleva. Neste sentido, para contribuir com o crescimento econômico do país, é preciso investir em novos projetos para geração de energia hidrelétrica e em fontes alternativas, como a biomassa e a nuclear (CNI, 2012).

A utilização do petróleo, carvão, gás natural e outros hidrocarbonetos não é uma solução sustentável a longo prazo. Além dos recursos serem finitos, 
esgotáveis, geram efeitos deletérios, como por exemplo, as mudanças climáticas resultantes das emissões de dióxido de carbono $\left(\mathrm{CO}_{2}\right)$. Muitos materiais perigosos são descarregados na natureza a partir de diferentes fontes, com baixo nível de controle. Neste contexto, a energia nuclear pode vir a desempenhar um papel relevante, complementando ou substituindo outras formas de energia, atendendo às necessidades da sociedade (MOURA 2008).

\subsection{Energia nuclear}

A energia nuclear é a energia armazenada no núcleo dos átomos, mantendo prótons e nêutrons juntos. Esta energia é fóssil tendo em vista que os elementos foram formados há bilhões de anos. O minério de urânio é toda concentração natural de minerais na qual o urânio ocorre em proporções e condições que permitam sua exploração econômica (REIS et al, 2005).

O elemento químico urânio é um metal branco-níquel, pouco menos duro que o aço e encontra-se em estado natural, nas rochas da crosta terrestre. Sua principal aplicação é na geração de energia elétrica e na produção de material radioativo para uso na medicina e na agricultura. O urânio encontrado na natureza é constituído de uma mistura de três isótopos: 99,3\% com massa 238; 0,7\% com massa 235; e traços com massa 234. Estes três isótopos são radioativos, ou seja, são instáveis e, com o passar do tempo, decaem, emitindo radiação alfa e convertendo-se respectivamente nos isótopos 234, 231 e 230 do elemento tório. Estes, por sua vez, também se transmutam para outros elementos numa longa série que termina nos isótopos estáveis do chumbo 206, 207 e 208, respectivamente. O que é aproveitado nos reatores nucleares não é a radioatividade do urânio, mas sim a propriedade de se fissionar (quebrar-se ou partir-se) e liberar grande quantidade de energia quando atingido por um nêutron (REIS et al, 2005).

A prospecção e a pesquisa de minerais de urânio têm por finalidade básica localizar, avaliar e medir reservas de urânio. Tais trabalhos começam pela seleção de áreas promissoras, indicadas por exame de fotografias aéreas, imagens de radar e de satélite. O urânio, para ser utilizado como combustível num reator nuclear para geração de eletricidade, deve ser processado por uma série de etapas: a este conjunto de etapas dá-se nome o nome de ciclo do combustível 
nuclear. Estas etapas serão abordadas de forma mais detalhada ao longo deste capítulo.

O Brasil possui hoje a $7^{\mathrm{a}}$ maior reserva geológica de urânio do mundo. As reservas brasileiras estão localizadas em seis estados com participação diferenciada em cada um, e 79\% das reservas estão situadas nos estados da Bahia e do Ceará (Lagoa Real - Caetité (BA) com 32,6\% e Itatiaia (CE) com 46\%). As pesquisas na área de identificação de reservas de urânio no Brasil não foram completadas para todo o território nacional. As reservas já inferidas são suficientes para suprir o consumo atual por muito tempo. O urânio tem uma participação de 1\% na matriz energética brasileira, e o consumo na sua totalidade é para suprir as usinas nucleares de Angra dos Reis. Na geração de eletricidade, a participação das usinas nucleares é de 2,6\%. Hoje estão em funcionamento as usinas Angra I e Angra II com 635 MW e 1.345 MW de potência respectivamente (REIS et al, 2005; ELETRONUCLEAR, 2011).

A seguir, o ciclo do combustível nuclear será descrito com mais detalhes.

\subsection{O ciclo do combustível nuclear}

O ciclo do combustível nuclear pode ser definido como um conjunto de processos que faz uso de materiais nucleares que posteriormente retornam ao estado normal. Ele se inicia com a mineração de materiais nucleares e termina com a segura disposição desses materiais na natureza, após seu uso (OLIVEIRA, 2008).

O urânio passa por diversos processos até produzir energia em um reator nuclear, como mostrado esquematicamente na FIG. 1.

O conjunto completo de processos para produzir o combustível nuclear a partir do minério de urânio é conhecido como 'front end' do ciclo do combustível nuclear e compreende: a mineração e o beneficiamento do minério de urânio para produção de uma mistura contendo em maior proporção o $\cup_{3} \mathrm{O}_{8}$, o qual é mais conhecido como yellow cake; a conversão do yellow cake em óxido de urânio $\left(\mathrm{UO}_{2}\right)$ e hexafluoreto de urânio $\left(\mathrm{UF}_{6}\right)$; o enriquecimento isotópico do $\mathrm{UF}_{6}$; e a fabricação de pastilhas de combustível, a partir do óxido urânio natural $\left(\mathrm{UO}_{2}\right)$ ou da conversão do $\mathrm{UF}_{6}$ enriquecido em $\mathrm{UO}_{2}$, para formar o elemento combustível. 


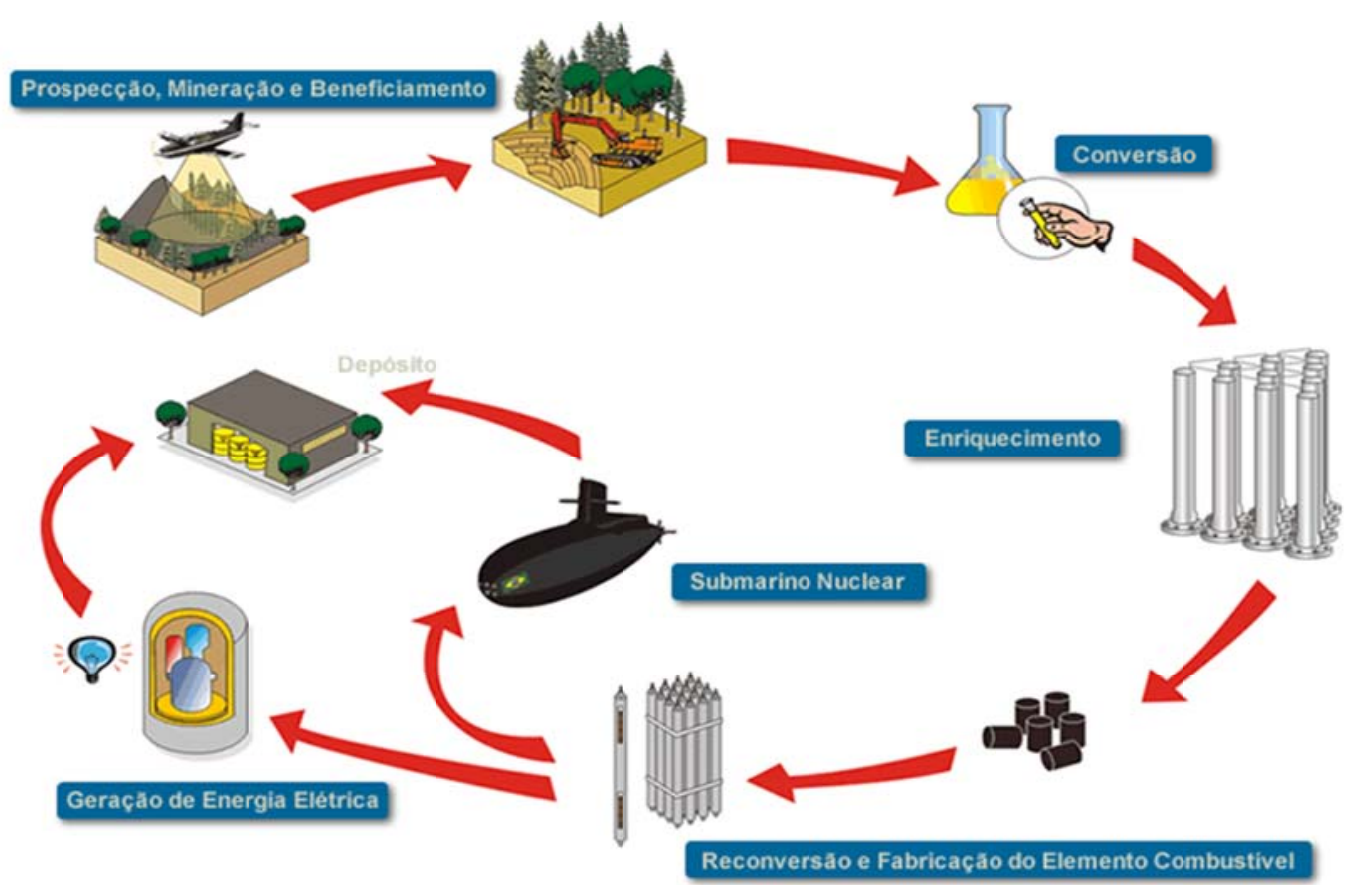

FIGURA 1 - Ciclo do Combustível Nuclear (CTMSP, 2011)

O combustível é então irradiado em um reator nuclear para produção de energia. Após produzir energia térmica no reator, o combustível nuclear torna-se combustível irradiado. O combustível irradiado é então tratado em um conjunto de processos conhecidos como o 'back end' do ciclo do combustível nuclear, que são os seguintes: armazenagem temporária no reator; existe também a armazenagem temporária do combustível queimado em meio úmido ou seco fora do reator e a disposição do combustível nuclear queimado em repositório profundo; o reprocessamento para separação do urânio $(\mathrm{U})$ e plutônio $(\mathrm{Pu})$ dos produtos de rejeito, se for reciclado; e a armazenagem monitorada fora do reator ou a disposição final dos rejeitos de alto nível de atividade (OLIVEIRA, 2008).

As informações a seguir, foram extraídas da Apostila do Curso: Tecnologia Nuclear Básica - Materiais e Ciclo do Combustível Nuclear, ministrado por AQUINO (2009) na pós-graduação do IPEN e na dissertação de mestrado de KOMATSU (2008), ambos detalham o processo do ciclo do combustível nuclear.

\subsubsection{Extração do urânio}

$\mathrm{O}$ urânio é removido do minério pela lixiviação com ácido sulfúrico - $\mathrm{H}_{2} \mathrm{SO}_{4}$. $\mathrm{O}$ processo se caracteriza por fazer "chover" $\mathrm{H}_{2} \mathrm{SO}_{4}$ em cima de uma pilha de 
pedras do minério. A solução resultante, de sulfato de uranilo $-\mathrm{UO}_{2} \mathrm{SO}_{4}$ é recolhida para sofrer a primeira purificação dentro do ciclo. Embora, após a obtenção do yellow cake, exista uma etapa específica de purificação do urânio, ao percorrer o ciclo do combustível, o material é purificado por diversas vezes, haja vista que isso ocorre em cada mudança de fase (extrações) ou de estado físico (sólido $\Leftrightarrow$ líquido $\Leftrightarrow$ gasoso). Nesta etapa, o urânio é purificado por extração com solvente, no caso uma amina terciária chamada tri-octil amina - TOA. As equações químicas que descrevem o processo da extração do urânio com TOA são apresentadas, de forma simplificada, a seguir:

$2\left(\mathrm{R}_{3} \mathrm{NH}\right)_{2} \mathrm{SO}_{4}(\mathrm{org})+\left[\mathrm{UO}_{2}\left(\mathrm{SO}_{4}\right)_{3}\right]^{4-}(\mathrm{aq}) \leftrightarrows\left(\mathrm{R}_{3} \mathrm{NH}\right)_{2} \mathrm{UO}_{2}\left(\mathrm{SO}_{4}\right)_{3}(\mathrm{org})+2 \mathrm{SO}_{4}{ }^{2-}(\mathrm{aq})$ $\left(\mathrm{R}_{3} \mathrm{NH}\right)_{2} \mathrm{UO}_{2}\left(\mathrm{SO}_{4}\right)_{3}(\mathrm{org})+4 \mathrm{NaCl}(\mathrm{aq}) \leftrightarrows 2 \mathrm{R}_{3} \mathrm{NHCl}(\mathrm{org})+2 \mathrm{Na}_{2} \mathrm{SO}_{4}(\mathrm{aq})+\mathrm{UO}_{2} \mathrm{SO}_{4}(\mathrm{aq})$

O urânio, após esta etapa inicial de purificação, que objetiva em particular a remoção de zircônio e molibdênio, é precipitado com amônia dando origem ao yellow cake, que nada mais é do que um diuranato de amônio - DUA - $\left(\mathrm{NH}_{4}\right)_{2} \mathrm{U}_{2} \mathrm{O}_{7}$ com um teor de impurezas inaceitável para o uso nuclear.

Na química do urânio dois íons são considerados de grande importância, o uranilo $\mathrm{UO}_{2}{ }^{++}$formado em meio ácido, e o uranato $\mathrm{U}_{2} \mathrm{O}_{7}{ }^{--}$formado em meio básico.

A etapa de tratamento do minério após ser retirado da mina, que envolve a britagem, a lixiviação, a extração com solvente tipo amina terciária e a produção do yellow cake é chamada de beneficiamento do urânio.

A decisão de construir um reator tipo PWR refrigerado a água natural implica em outra que é de se trabalhar com urânio enriquecido. O processo de enriquecimento necessita de urânio em uma forma química estável, no estado gasoso, sob condições específicas de temperatura e pressão (sublimação $56,4^{\circ} \mathrm{C}$ - $760 \mathrm{mmHg}$; ponto triplo $64,052^{\circ} \mathrm{C}$ - $1134 \mathrm{mmHg}$ ). O único composto de urânio que preenche estes requisitos é o hexafluoreto de urânio - UF $F_{6}$. O flúor $\left(F_{2}\right)$ tem um único isótopo estável, o que por si só também é uma vantagem.

Há, então, a necessidade de traçar uma rota química para chegar até o $\mathrm{UF}_{6}$ e obter um produto com os requisitos de pureza exigidos para a sua aplicação nuclear, com a maior economia de energia possível. 
As etapas envolvidas nesse trajeto são:

\subsubsection{Purificação do urânio}

Justificada pela necessidade da obtenção de um material com o chamado "grau nuclear". Visa à remoção de impurezas capazes de absorverem os nêutrons do sistema (B, Cd, Hf), consequentemente diminuindo a eficiência da produção de energia por meio da fissão do ${ }^{235} \mathrm{U}$ e impedir a presença de outras impurezas (Fe, $\mathrm{Cr}$, Ni) que comprometam as propriedades cerâmicas e mecânicas do combustível nuclear. A técnica adotada é a extração com solvente em coluna pulsada. O solvente, no caso, é o tri-n-butil fosfato - TBP. O processo é operado em um sistema com três colunas na qual a primeira é a de extração, a segunda a de lavagem e a terceira a de reversão (térmica). O produto final é uma solução de nitrato de uranilo com cerca de $100 \mathrm{gU} / \mathrm{L}$.

A ocorrência natural do urânio se dá com a composição isotópica relativa de $99,3 \%$ de ${ }^{238}$ U e $0,7 \%$ de ${ }^{235} U$. O material físsil em pequena quantidade obriga a remoção dos elementos que possam competir com ele nas reações neutrônicas. A especificação para alguns elementos em um concentrado de urânio de "grau nuclear" é apresentada na TAB. 1, com os teores máximos permissíveis de impurezas na ordem de ppm (partes por milhão).

TABELA 1 - Teores máximos permissíveis de impurezas do urânio de "grau nuclear" (ULRICH, 2001)

\begin{tabular}{lc}
\hline \multicolumn{1}{c}{ Elemento } & Valor máximo permissível $(\mathrm{ppm})$ \\
\hline Boro & 0,2 \\
Cádmio & 0,2 \\
Cloro & 5 \\
Magnésio & 25 \\
Manganês & 25 \\
Prata & 1 \\
\hline
\end{tabular}




\subsubsection{Precipitação do DUA}

Justificada pela necessidade de se trabalhar com volumes menores. A solução de $100 \mathrm{gU} / \mathrm{L}$ corresponde a uma estocagem de $100 \mathrm{~kg} / \mathrm{m}^{3}$ ao passo que sob a forma sólida este valor pode ser 20 vezes maior, podendo chegar a $2.000 \mathrm{~kg} / \mathrm{m}^{3}$. Também são minimizados os problemas de corrosão e vazamento, melhorando a segurança como um todo. Outra vantagem do DUA é que ao ser calcinado gera somente óxidos de urânio, ao contrário do diuranato de sódio ou de potássio.

$$
\left(\mathrm{NH}_{4}\right)_{2} \mathrm{U}_{2} \mathrm{O}_{7} \stackrel{\Delta}{\Rightarrow} 2 \mathrm{UO}_{3}+2 \mathrm{NH}_{3} \uparrow+\mathrm{H}_{2} \mathrm{O} \uparrow
$$

\subsubsection{Fabricação de tetrafluoreto de urânio $\left(\mathrm{UF}_{4}\right)$}

Justificada pela necessidade de se economizar energia elétrica no ciclo. Para preparar $U F_{6}$ é preciso flúor $-F_{2}$ obtido por eletrólise do fluoreto de hidrogênio - $\mathrm{HF}$, ao passo que a preparação do $\mathrm{UF}_{4}$ pode ser feita usando diretamente o $\mathrm{HF}$, que é obtido pela reação da fluorita - $\mathrm{CaF}_{2}$ com o ácido sulfúrico $-\mathrm{H}_{2} \mathrm{SO}_{4}$.

O reator usado na produção de $U_{4}$ é do tipo leito móvel e se caracteriza por ter duas regiões distintas. A primeira, na parte superior, é onde ocorre a redução do $\mathrm{UO}_{3}$ a $\mathrm{UO}_{2}$, e o hidrogênio - $\mathrm{H}_{2}$ usado para essa reação é obtido no próprio meio, pelo craqueamento da amônia. A segunda região, continuação da primeira, é o local onde se produz o $\mathrm{UF}_{4}$.

$$
\begin{aligned}
& \triangle \\
& 2 \mathrm{NH}_{3} \Rightarrow 3 \mathrm{H}_{2}+\mathrm{N}_{2} \text { (craqueamento da amônia) } \\
& \mathrm{UO}_{3}+\mathrm{H}_{2} \Rightarrow \mathrm{UO}_{2}+\mathrm{H}_{2} \mathrm{O} \text { (redução do } \mathrm{UO}_{3} \text { ) } \\
& \mathrm{UO}_{2}+4 \mathrm{HF} \Rightarrow \mathrm{UF}_{4}+2 \mathrm{H}_{2} \mathrm{O} \text { (fluoretação do } \cup_{2} \text { ) }
\end{aligned}
$$

A produção industrial do HF é feita a partir da fluorita, segundo equação:

$\mathrm{CaF}_{2}+\mathrm{H}_{2} \mathrm{SO}_{4} \Rightarrow 2 \mathrm{HF}+\mathrm{CaSO}_{4}$

\subsubsection{Fabricação do hexafluoreto de urânio $\left(\mathrm{UF}_{6}\right)$}

Esta etapa é necessária para obter o urânio na forma química adequada para realizar o enriquecimento isotópico. $\mathrm{O} \mathrm{UF}_{6}$ é a única forma química em que o 
urânio é estável, em condições específicas de temperatura e pressão, no estado gasoso (sublimação $56,4^{\circ} \mathrm{C}$ - $760 \mathrm{mmHg}$; ponto triplo $64,052^{\circ} \mathrm{C}$ - $1134 \mathrm{mmHg}$ ).

$\mathrm{UF}_{4}+\mathrm{F}_{2} \Rightarrow \mathrm{UF}_{6}$ (fluoração do $U \mathrm{~F}_{4}$ )

O flúor é obtido por eletrólise do HF

$2 \mathrm{HF}+\mathrm{e}^{-} \Rightarrow \mathrm{F}_{2}+\mathrm{H}_{2}$ (eletrólise do HF)

\subsubsection{Enriquecimento isotópico em ${ }^{235} \mathrm{U}$}

O enriquecimento isotópico do urânio em ${ }^{235} \mathrm{U}$ é uma das etapas do ciclo do combustível nuclear necessária para fabricar elementos combustíveis para reatores de pesquisa e/ou PWR (água natural/urânio enriquecido). Três são os principais processos adotados para aumentar a fração de ${ }^{235} U$, que na natureza é de 0,7\%, para 4,2\% em reatores PWR: difusão gasosa; ultracentrifugação; jato centrífugo. O jato centrífugo é um processo de enriquecimento isotópico que foi modelado pela Alemanha e transferido para o Brasil dentro do convênio firmado entre os dois países para o desenvolvimento conjunto de programa nuclear com finalidade de gerar energia elétrica. Nos anos 80 ainda não existia tecnologia para fabricar os equipamentos necessários para o domínio desse processo físicoquímico. Outra iniciativa foi tomada com a criação do Projeto Paralelo (alternativo ao Programa Oficial - Acordo Brasil-Alemanha), gerenciado pela Marinha do Brasil e, inicialmente, fazendo uso do quadro de pesquisadores do IPEN. A tecnologia nesse caso adotada foi a da ultracentrifugação. O projeto atingiu o seu objetivo conseguindo colocar o Brasil no seleto grupo dos detentores da tecnologia do enriquecimento isotópico do urânio em ${ }^{235} \mathrm{U}$.

O urânio sob a forma química de $\mathrm{UF}_{6}$, não é apropriado para a fabricação do combustível, havendo necessidade de uma transformação, cuja etapa é denominada reconversão, para uma forma adequada, no caso das usinas brasileiras, o $\cup_{2}$.

\subsubsection{Reconversão}

As rotas para obtenção do combustível nuclear podem ser várias, e o Brasil domina três delas. 
1) Reconversão por meio de hidrólise

$$
\mathrm{UF}_{6}(\mathrm{~g})+2 \mathrm{H}_{2} \mathrm{O}(\mathrm{l}) \Rightarrow \mathrm{UO}_{2} \mathrm{~F}_{2}(\mathrm{aq})+4 \mathrm{HF}+\Delta
$$

As etapas subsequentes do processo são as convencionalmente usadas na conversão: precipitação, calcinação e redução.

2) Reconversão de $\mathrm{UF}_{6} \mathrm{a} \mathrm{UF}_{4}$ - processo parede quente

$\mathrm{UF}_{6}(\mathrm{~g})+\mathrm{H}_{2}(\mathrm{~g}) \Rightarrow \mathrm{UF}_{4}(\mathrm{~s})+2 \mathrm{HF}(\mathrm{g})+\mathrm{Q}$

Este processo é mais adequado para a fração empobrecida em ${ }^{235} U$, pois é uma etapa intermediária na fabricação de urânio metálico.

O processo mais comum para obtenção de $\mathrm{U}^{0}$ é a magnesiotermia.

$$
\mathrm{UF}_{4}(\mathrm{~s})+2 \mathrm{Mg}^{0}(\mathrm{~s}) \Rightarrow \mathrm{U}^{0}+2 \mathrm{MgF}_{2}
$$

3) Reconversão via tricarbonato de amônio e uranilo - TCAU

$$
\mathrm{UF}_{6}+10 \mathrm{NH}_{3}+3 \mathrm{CO}_{2}+5 \mathrm{H}_{2} \mathrm{O} \Rightarrow\left(\mathrm{NH}_{4}\right)_{4} \mathrm{UO}_{2}\left(\mathrm{CO}_{3}\right)_{3}+6 \mathrm{NH}_{4} \mathrm{~F}
$$

O TCAU é secado e reduzido com $\mathrm{H}_{2}$ para a obtenção do $\mathrm{UO}_{2}$. Este processo foi desenvolvido e adotado pelo IPEN para fabricação dos combustíveis à base de $\mathrm{UO}_{2}$.

Uma questão sobressai nas etapas de reconversão: a criticalidade. A massa crítica de um material físsil pode ser aumentada se ao distanciar da geometria que mais a favorece, que é a esférica. Os equipamentos que trabalham com urânio enriquecido são construídos com critérios geométricos que desfavorecem o acúmulo do material físsil em condições de criticalidade.

\subsection{Programa Nuclear Brasileiro - PNB e Programa Nuclear da Marinha - PNM}


O Programa Nuclear Brasileiro faz parte do Plano de Ação em Ciência, Tecnologia e Inovação - PACTI que por sua vez está incluso no Plano de Aceleração do Crescimento - PAC do governo brasileiro.

O PACTI 2007-2010 basicamente elenca quatro prioridades estratégicas, expressas em 21 linhas de ação e 87 Programas. O Programa 18 é sobre o Programa Nuclear Brasileiro que em linhas gerais reúne as seguintes metas:

- Consolidação do arcabouço legal da área Nuclear;

- Ampliação do Ciclo do Combustível Nuclear na INB;

- Conclusão da planta piloto de produção de $\mathrm{UF}_{6}$ (conversão) em Aramar;

- Capacitação e adequação tecnológica da NUCLEP para a fabricação de componentes das novas usinas nucleares;

- Implementar uma Política Brasileira de Gerenciamento de Rejeitos Radioativos. Criação da Empresa Brasileira de Rejeitos Radioativos - EBRR;

- Empresa Brasileira de Radiofármacos - EBR; e

- Ações de PD \& I e capacitação voltadas para a retomada do PNB (GONÇALVES, 2012).

O setor nuclear brasileiro é representado pela Indústria Nuclear Brasileira INB, a Comissão Nacional de Energia Nuclear - CNEN e institutos de C\&T, a Nuclebrás Equipamentos Pesados - NUCLEP, Angra I e II, o Sistema de Proteção ao Programa Nuclear Brasileiro - SIPRON e o Centro Tecnológico da Marinha em São Paulo - CTMSP.

$\mathrm{Na}$ atualidade, o principal objetivo do Programa que está sendo desenvolvido pelo CTMSP, é estabelecer a competência técnica autóctone para projetar, construir, comissionar, operar e manter reatores do tipo Reator de Água Pressurizada - Pressurized Water Reactor (PWR) e produzir o seu combustível. Dominada essa tecnologia, ela poderá ser empregada na geração de energia elétrica, quer para iluminar uma cidade, quer para propulsão naval de submarinos. A conquista da tecnologia necessária à geração de energia núcleoelétrica, para uso em propulsão naval, passa por complexos estágios de desenvolvimento, merecendo destaque: o domínio completo do ciclo do combustível nuclear - já conquistado; e o desenvolvimento e construção de uma planta nuclear de geração 
de energia elétrica - em andamento. O PNM é, pois, dividido em dois grandes projetos: o Projeto do Ciclo do Combustível e o Projeto do Laboratório de Geração NúcleoElétrica - LABGENE (MB, 2011).

Os submarinos são poderosas armas dissuasórias, e suas características operacionais conferem importante dimensão ao Poder Naval, um dos pilares do nosso Sistema de Defesa. No contínuo esforço para dotar o Brasil desses importantes meios, a Marinha prontificou em 21 de julho de 2006 o quarto submarino (S) convencional, construído no Arsenal de Marinha do Rio de Janeiro - AMRJ, totalizando cinco navios desse tipo.

Paralelamente, desde 1979, a Marinha do Brasil desenvolve seu Programa Nuclear, cujo propósito é dominar a tecnologia necessária ao projeto e construção de um submarino com propulsão nuclear, arma com poder dissuasório ainda maior que o do submarino convencional, por sua capacidade de operar quase que indefinidamente sem depender da atmosfera (MB, 2011).

\subsection{Centro Tecnológico da Marinha em São Paulo - CTMSP}

O Centro Tecnológico da Marinha em São Paulo é uma organização militar que foi criada pelo Decreto n 93.439, de 17 de outubro de 1986 (BRASIL, 1986), sob o nome de Coordenadoria para Projetos Especiais (COPESP), tendo sua denominação alterada em 1995 para Centro Tecnológico da Marinha em São Paulo. No CTMSP é desenvolvido o Programa Nuclear da Marinha do Brasil PNM que visa à capacitação no domínio dos processos tecnológicos, industriais e operacionais de instalações nucleares aplicáveis à propulsão naval. Em virtude desse grande campo de pesquisa, o CTMSP está dividido em dois sítios, CTMSP - Sede e Centro Experimental Aramar (CEA). O CTMSP - Sede, está localizado na cidade de São Paulo, inserido dentro da Universidade de São Paulo (USP), onde trabalham servidores militares e civis que exercem atividades técnicas de engenharia, pesquisa e desenvolvimento, gerenciamento de projetos e atividades administrativas (CTMSP, 2011a).

O CEA está localizado em Iperó, São Paulo, a cerca de 120 km da capital, onde estão sendo implantadas as principais oficinas, usinas, laboratórios e protótipos desenvolvidos pelo CTMSP (FIG. 2). Entre eles, destacam-se o Laboratório Radioecológico (LARE), responsável pelo controle dos efluentes e 
pela monitoração de amostras ambientais ao redor do Centro, a Unidade de Produção de Hexafluoreto de Urânio (USEXA) e o Laboratório de Geração de Energia NúcleoElétrica (LABGENE), que será uma instalação experimental em terra de uma planta de propulsão nuclear (CTMSP, 2011a).

O CEA encontra-se sediado na Fazenda Ipanema ou na Floresta Nacional de Ipanema (FLONA). Segundo a Lei Federal n 9.985, de 18i de julho de 2000, a Floresta Nacional é uma área com cobertura florestal de espécies predominantemente nativas e tem como objetivo básico o uso múltiplo sustentável dos recursos florestais e a pesquisa científica, com ênfase em métodos para exploração sustentável de florestas nativas (BRASIL, 2000). A Floresta Nacional de Ipanema (FLONA Ipanema) criada pelo Decreto Federal $n^{\circ} 530$, de 20 de maio de 1992, e administrada pelo Instituto Chico Mendes de Conservação da Biodiversidade (ICMBio), é uma unidade de conservação de uso sustentável (BRASIL, 1992).

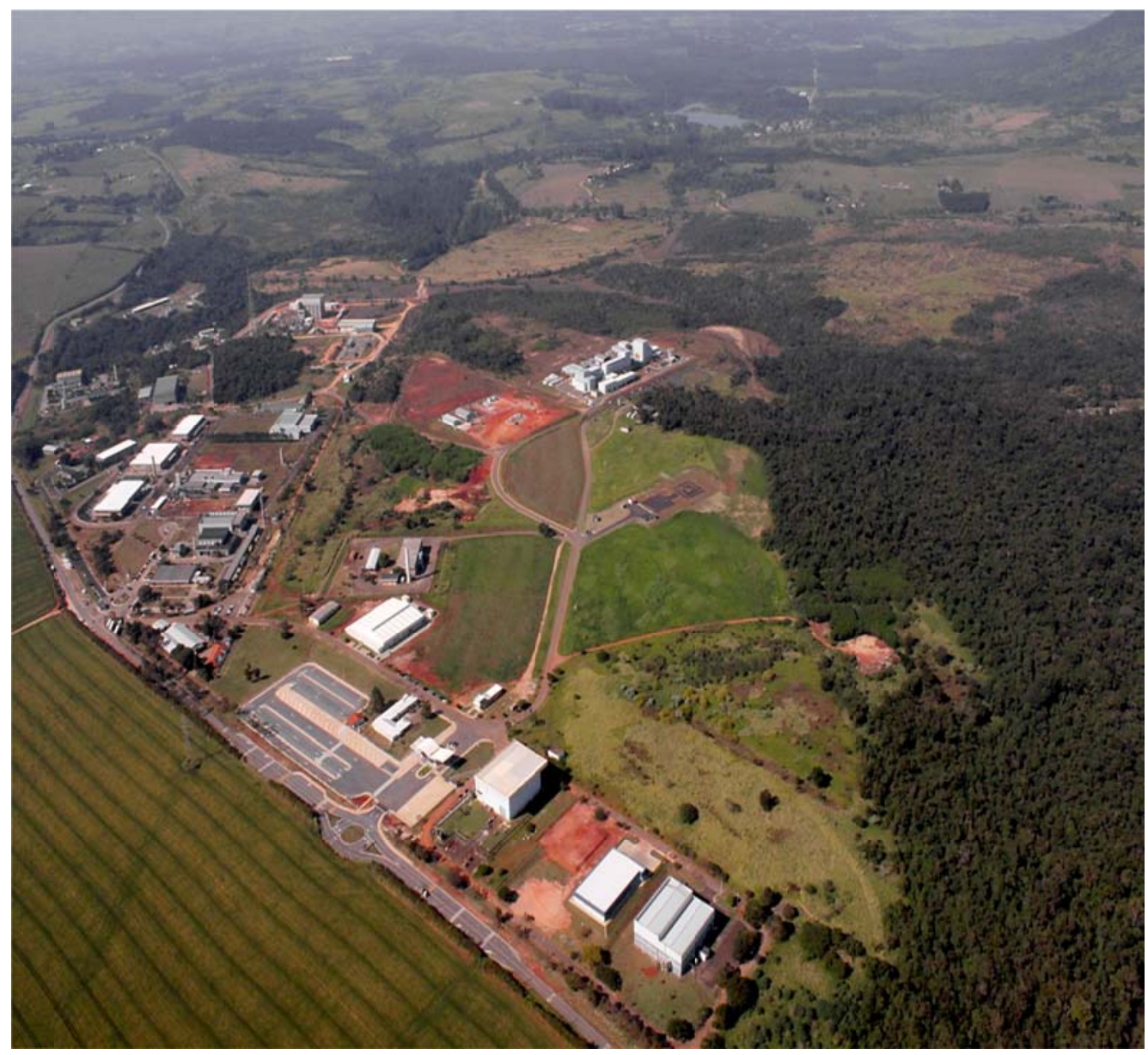


FIGURA 2 - Vista aérea do CEA (crédito: Lucas Roberto Cremasco)

A USEXA é responsável pela conversão do concentrado de urânio em hexafluoreto de urânio atenderá às necessidades do Programa Nuclear da Marinha. As usinas nucleares tipo PWR (Pressurized Water Reactor) utilizam urânio enriquecido em urânio-235 e o processo de ultracentrifugação requer urânio sob a forma gasosa.

A instalação completa da USEXA (FIG. 3) é composta de várias unidades de processo, utilidades e de apoio, cada uma prevista para realizar uma determinada etapa de fabricação do $U_{6}$. Os processos compreendem resumidamente as seguintes sequências de etapas químicas: purificação do concentrado de urânio obtendo-se nitrato de uranilo (NTU); produção de trióxido de urânio $\left(\mathrm{UO}_{3}\right)$, por meio de reações químicas e calcinação; produção de tetrafluoreto de urânio $\left(\mathrm{UF}_{4}\right)$, em reator tipo leito móvel, por meio de reações químicas com fluoreto de hidrogênio e outros elementos em ambiente controlado; produção de flúor $\left(F_{2}\right)$ em células eletrolíticas a partir do fluoreto de hidrogênio $(\mathrm{HF})$; produção e purificação de hexafluoreto de urânio $\left(\mathrm{UF}_{6}\right)$, por meio da reação do $\mathrm{UF}_{4}$ com $\mathrm{F}_{2}$ em reatores tubulares. A previsão da produção é de 40 toneladas de hexafluoreto de urânio por ano.

O número atribuído a cada edifício ou processo que no conjunto formam a USEXA está listado a seguir:

C10.11 - Unidade de Purificação de Nitrato de Uranilo (NTU);

C10.12 - Unidade de Produção de Trióxido de Urânio $\left(\mathrm{UO}_{3}\right)$;

C10.13 - Unidade de Produção de Tetrafluoreto de Urânio $\left(\mathrm{UF}_{4}\right)$;

C10.15 - Unidade de Estocagem de Matéria-Prima;

C10.21 - Unidade de Produção de Hexafluoreto de Urânio (UF ${ }_{6}$ );

C10.22 - Unidade de Produção de Flúor $\left(F_{2}\right)$;

C10.23 - Unidade de Destilação de Hexafluoreto de Urânio (UF ${ }_{6}$ );

C10.31 - Unidade de Recuperação de Urânio e Tratamento de Rejeitos;

C10.32 - Unidade de Armazenamento Inicial de Rejeitos da USEXA;

C10.41 - Utilidades;

C10.42 - Unidade de Estocagem de Produtos Químicos;

C10.43 - Subestação; 
C10.44 - Interligação; e C10.51 - Apoio.

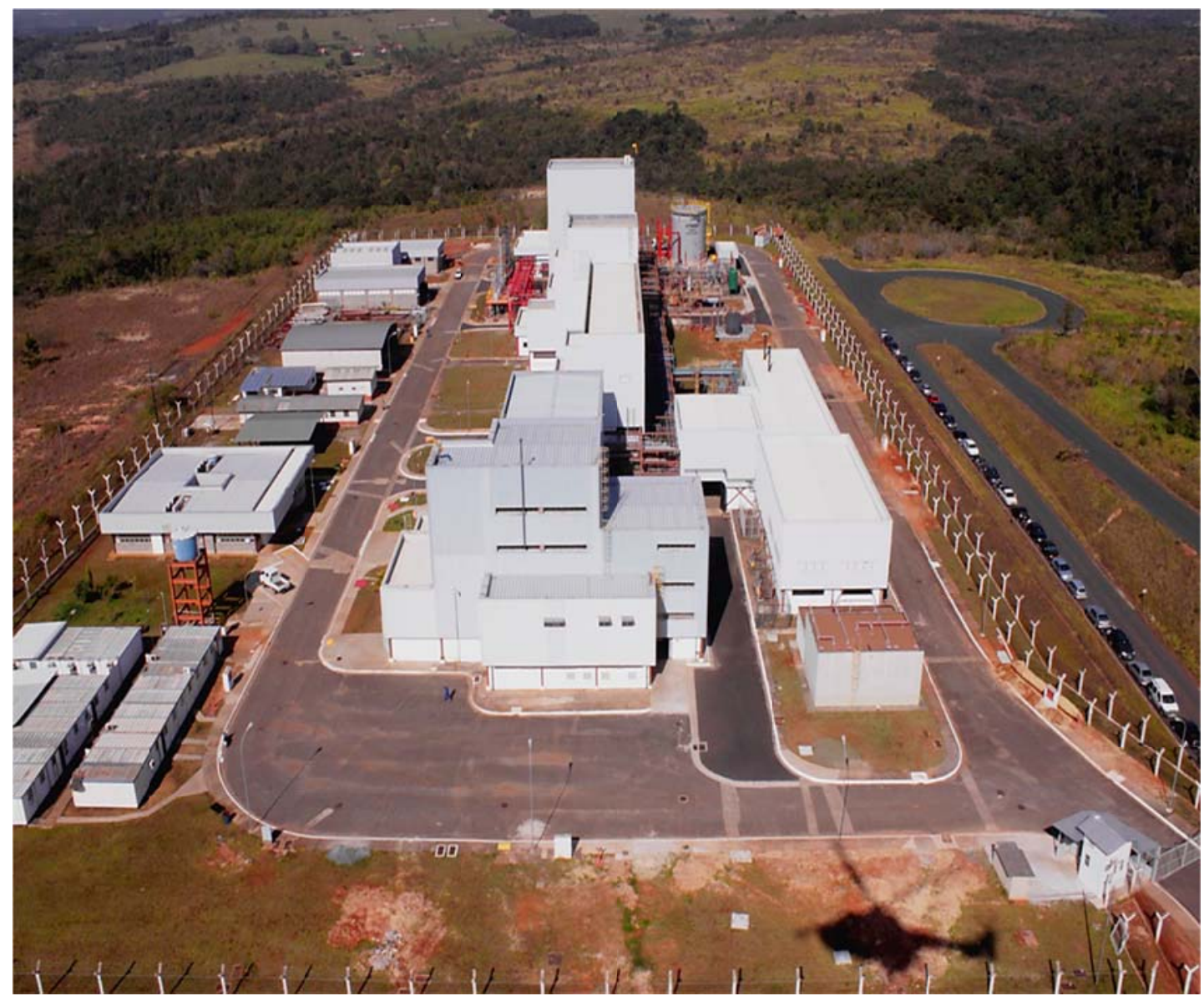

FIGURA 3 - Vista aérea da USEXA (crédito: Lucas Roberto Cremasco)

Atualmente, cinco países operam em escala comercial a conversão do concentrado de urânio para o hexafluoreto de urânio: a Comuhrex (AREVA) França, com capacidade de 14.000 t UF/ano; a Cameco - Canadá, com capacidade de 12.500 t UF/ano; a BNFL - Inglaterra, capacidade de $6.000 \mathrm{t}$ UF/ano; a ConverDyn (Honeywell) - USA, com capacidade de 15.000 t UF 6 /ano; e a Rosatom - Rússia, com capacidade 18.000 t UF/ano (UFRJ, 2012).

O Brasil já domina a tecnologia da fase de conversão do ciclo do combustível nuclear e quando a USEXA estiver em plena operação, o Brasil deixará de importar do Canadá e dos EUA, o hexafluoreto de urânio. O Brasil ocupa o $7^{\circ}$ lugar do ranking em minério de urânio, com 278,7 mil toneladas em reservas conhecidas e correspondente a cerca de $6 \%$ do volume total mundial, e 
apenas $1 / 3$ do território nacional foi explorado. O domínio da fase de conversão do ciclo do combustível agregará valor ao minério de urânio e assim será fornecido combustível nuclear genuinamente nacional para os reatores em operação e para o submarino nuclear, garantindo assim a soberania nacional (ANEEL, 2012).

\subsection{Sistema de Gestão Ambiental}

O gerenciamento ambiental é importante para a organização manter-se consciente das interações que seus produtos, processos e atividades têm com o meio ambiente, desta forma atingir continuamente e melhorar o nível do desempenho ambiental desejado.

As normas de gestão ambiental têm por objetivo prover as organizações de elementos de um Sistema de Gestão Ambiental (SGA) eficaz que possam ser integrados a outros requisitos da gestão, e auxiliá-las a alcançar seus objetivos ambientais e econômicos (ABNT, 2004).

A Norma ABNT NBR ISO 14001:2004 baseia-se na metodologia conhecida como Plan Do Check Act - Planejar, Executar, Verificar e Agir. O Ciclo PDCA pode ser brevemente descrito da seguinte forma: Planejar: Estabelecer os objetivos e processos necessários para atingir os resultados em concordância com a política ambiental da organização; Executar: Implementar os processos; Verificar: Monitorar e medir os processos em conformidade com a política ambiental, objetivos, metas, requisitos legais e outros, e relatar os resultados; Agir: Agir para continuamente melhorar o desempenho do sistema da gestão ambiental (ABNT, 2004).

O Sistema de Gestão Ambiental é uma ferramenta importante, pois permite a ampliação das interfaces do empreendimento com o meio ambiente. As instalações nucleares e as questões ambientais são, na maioria das vezes, abordadas somente sobre o prisma da radiação e conduzidas por Programas de Monitoramento Ambiental. O SGA permite abordar, por exemplo, programas de otimização dos recursos como água e energia e de resíduos sólidos comuns em qualquer empreendimento e usina nuclear.

Este trabalho pretende trazer uma contribuição ao Programa Nuclear Brasileiro no tocante à parte executada pelo CTMSP, não só na construção de um 
submarino como no desenvolvimento de tecnologia para as usinas térmicas na geração de eletricidade, agregando novas ferramentas à antiga preocupação do CTMSP com o meio ambiente (MATTIOLO \& AQUINO, 2009).

\subsection{Objetivos}

O objetivo deste trabalho é propor um modelo de Sistema de Gestão Ambiental para a Unidade de Produção de Hexafluoreto de Urânio do CTMSP USEXA desde a fase de planejamento, implantação até a fase de operação, melhorando a compreensão de elementos do sistema de gestão ambiental, em especial os treinamentos.

\subsection{Justificativa para desenvolvimento do trabalho}

Sendo o CTMSP uma instituição que participa do Programa Nuclear Brasileiro e uma instalação científica que desenvolve tecnologia genuinamente nacional, a implementação dessas diretrizes atendem ao Decreto-lei $n^{\circ} 1809$ (BRASIL, 1980) que institui o Sistema de Proteção ao Programa Nuclear Brasileiro - SIPRON, em seu Artigo $1^{\circ}$ decreta que: “... a execução continuada de providências que visem a atender às necessidades de segurança do Programa Nuclear Brasileiro e de seu pessoal, bem como da população e do meio ambiente com ele relacionados" e também a Lei no 9605 (BRASIL, 1998) que "Dispõe sobre as sanções penais e administrativas derivadas de condutas e atividades lesivas ao meio ambiente, e dá outras providências" em sua Seção IV (Dos Crimes contra o Ordenamento Urbano e o Patrimônio Cultural) em seu Artigo 62 que diz que "Destruir, inutilizar ou deteriorar: I - bem especialmente protegido por lei, ato administrativo ou decisão judicial; e II - arquivo, registro, museu, biblioteca, pinacoteca, instalação científica ou similar protegido por lei, ato administrativo ou decisão judicial".

A Resolução CONAMA nº 237 (CONAMA, 1997) considera, dentre outras, a necessidade de se incorporar ao sistema de licenciamento ambiental os instrumentos de gestão ambiental, visando ao desenvolvimento sustentável e à melhoria contínua. Em seu Art. $4^{\circ}$ - compete ao Instituto Brasileiro do Meio Ambiente e dos Recursos Naturais Renováveis (IBAMA), o licenciamento ambiental, de empreendimentos e atividades com significativo impacto ambiental 
de âmbito nacional ou regional, e no item IV deste artigo inclui, dentre as atividades as "destinadas a pesquisar, lavrar, produzir, beneficiar, transportar, armazenar e dispor material radioativo, em qualquer estágio, ou que utilizem energia nuclear em qualquer de suas formas e aplicações, mediante parecer da Comissão Nacional de Energia Nuclear (CNEN)". Consoante Resolução CONAMA no 01 (CONAMA, 1986), a qual estabelece em seu artigo $3^{\circ}$ que: "Dependerá de elaboração de estudo de impacto ambiental e respectivo Relatório de Impacto Ambiental - RIMA, a serem submetidos à aprovação do IBAMA, o licenciamento de atividades que, por lei, seja de competência federal". Isso coloca em evidência, sob o ponto de vista ambiental, qualquer instituição que participe do Programa Nuclear Brasileiro. 


\section{DESENVOLVIMENTO TEÓRICO E COLETA DE DADOS}

O trabalho foi desenvolvido com base nas normas NBR ISO 14001(ABNT, 2004), NBR ISO 14004 (ABNT, 2005) e NORTAM - Norma Técnica Ambiental nº 02 sobre Sistema de Gestão Ambiental (DPC, 2003).

Foram realizadas visitas técnicas à USEXA e entrevistas a funcionários da Usina.

$\mathrm{Na}$ maioria das vezes os SGA são realizados a partir de auditorias diagnósticas, neste trabalho foi realizada uma auditoria "prognóstica", a partir da leitura do Relatório Preliminar de Análise de Segurança - RPAS da USEXA (CTMSP, 2001) e do Relatório de Impacto Ambiental do CEA - RIMA (CTMSP, 1997), uma vez que a USEXA está em fase de comissionamento.

Foram gerados diagramas do processo de fabricação do UF6, planilhas de aspectos e impactos ambientais (segundo a NBR ISO 14001 (ABNT, 2004): "aspecto ambiental é o elemento das atividades ou produtos ou serviços de uma organização que pode interagir com o meio ambiente" e "impacto ambiental é qualquer modificação do meio ambiente, adversa ou benéfica, que resulte, no todo ou em parte, dos aspectos ambientais da organização"); em seguida os impactos ambientais foram avaliados; foi formulada uma proposta de política ambiental para USEXA; e determinado os objetivos, metas e sugestão de programas.

A fase seguinte foi dar as diretrizes para atendimento a cada item da norma NBR ISO 14001 (ABNT, 2004), identificando os documentos que já atendem ao SGA, os que precisam de adequação e aqueles que deverão ser elaborados. Os documentos sistêmicos da qualidade do CTMSP, referenciados neste trabalho, estão disponíveis na intranet.

\section{Sistema de Gestão Ambiental e Normas NBR ISO 14000}

O desenvolvimento sustentável estabelece novas exigências de desempenho ambiental para sociedade e a indústria que provocam muitas formas de mudanças, do uso doméstico de garrafas a decisões nacionais sobre políticas e investimentos (GILBERT, 1995). 
A prática de cumprimento das exigências de desempenho não é novidade em muitas empresas que lutam por melhorias contínuas. Para atendimentos a essas exigências, as empresas usam padrões de sistemas da qualidade como ferramentas para estabelecer práticas e procedimentos apropriados que garantam o sucesso.

Os modelos de uma boa gestão ambiental podem ser utilizados por qualquer organização, e, assim como a abordagem dos sistemas da qualidade, garante que o sucesso nessa área está se tornando uma consideração importante nos planos de desenvolvimento de muitas organizações, apoiando o progresso em direção à meta de desenvolvimento sustentável.

Os programas de gestão ambiental estabelecem as atividades a serem desenvolvidas, a sequência entre elas, bem como quem são os responsáveis pela sua execução. Normalmente devem abranger os aspectos ambientais mais importantes e buscar uma melhoria contínua, ampliando seu escopo de atuação com o passar do tempo. Devem possuir dinamismo e flexibilidade suficientes para se adaptar a mudanças que podem ocorrer tanto no seu ambiente imediato quanto no seu ambiente futuro (DONAIRE, 1999).

Existem várias propostas para o estabelecimento de um programa de gestão ambiental, dentre as quais se destacam as seguintes:

a) o Sistema Integrado de Gestão Ambiental, conhecido por Modelo Winter, desenvolvido a partir de 1972 pela empresa Ernst Winter \& Sohn com sede em Hamburgo e Norderstedt na Alemanha, posteriormente Backer, 1995 em sua obra propôs planos de ação que devem ser estabelecidos em sintonia com o que denomina Estratégia Ecológica da empresa (WINTER, 1999 e BACKER, 1999);

b) a primeira norma sobre SGA foi a BS 7750, criada pelo British Standards Institution (BSI) em 1992, embora não mais aplicada, sua importância é inquestionável, seja por ter sido a primeira norma sobre o assunto, seja porque seu modelo de SGA tornou-se um protótipo para as normas voluntárias criadas em outros países e para as normas da série ISO 14.000 sobre SGA (BARBIERI, 2004);

c) no Brasil, a ABIQUIM - Associação Brasileira de Indústria Química propõe aos seus associados o Programa Atuação Responsável, adotado oficialmente a partir de 1992 (ABIQUIM, 1999); e 
d) a partir de 1996 a maneira mais adequada de estabelecer um programa de gestão ambiental para as empresas foi seguir às Normas ISO - International Organization for Standardization 14.001 e 14.004 da ABNT - Associação Brasileira de Normas Técnicas que especificam diretrizes para o SGA - Sistema de Gestão Ambiental (ABNT, 2004 e ABNT, 2005).

A Norma NBR ISO 14001 (ABNT, 2004) tem por objetivo prover as organizações os elementos de um Sistema de Gestão Ambiental eficaz, passíveis de integração com os demais objetivos da organização. Sua concepção foi idealizada de forma a aplicar-se a todos os tipos e partes de organizações, independente de suas condições geográficas, culturais e sociais. Os principais requisitos necessários para implantação de um Sistema de Gestão Ambiental estão listados abaixo (a numeração dos itens da norma foi mantida):

4.2 Política ambiental

Fase em que a organização define uma política ambiental e assegura seu comprometimento com ela.

\subsection{Planejamento}

Fase em que organização formula um plano que satisfaça às políticas

4.3.1 Aspectos ambientais

4.3.2 Requisitos legais e outros

4.3.3 Objetivos, metas e programa(s)

4.4 Implementação e operação

Fase em que a organização coloca um plano em ação, fornecendo os recursos e mecanismos de apoio.

4.4.1 Recursos, funções, responsabilidades e autoridades

4.4.2 Competência, treinamento e conscientização

\subsubsection{Comunicação}

4.4.4 Documentação

4.4.5 Controle de documentos

4.4.6 Controle operacional

4.4.7 Preparação e resposta à emergências

4.5 Verificação

Fase em que a organização mede, monitora e avalia seu desempenho ambiental contra objetivos e alvos. 


\subsubsection{Monitoramento e medição}

4.5.2 Avaliação do atendimento a requisitos legais e outros

4.5.3 Não conformidade, ação corretiva e ação preventiva

4.5.4 Controle de registros

\subsubsection{Auditoria interna}

\subsection{Análise pela administração}

Fase em que a organização realiza uma análise crítica e implementa continuamente melhorias em seu SGA para alcançar melhorias no desempenho ambiental total.

O resultado da aplicação do Sistema de Gestão Ambiental depende do comprometimento de todos os níveis e funções, em particular da Alta Administração, e tem por objetivo um processo de melhoria contínua que pretende de forma constante superar os padrões vigentes. A implementação e operação de um Sistema de Gestão Ambiental são, na realidade, a aplicação de conceitos e técnicas de administração, particularizados para os assuntos de meio ambiente (MOURA, 2002).

Para atingir estas metas a Norma NBR ISO 14001 (ABNT, 2004) utiliza uma das ferramentas considerada importante e resume toda a implantação do processo do SGA, que é o ciclo PDCA (FIG. 3).

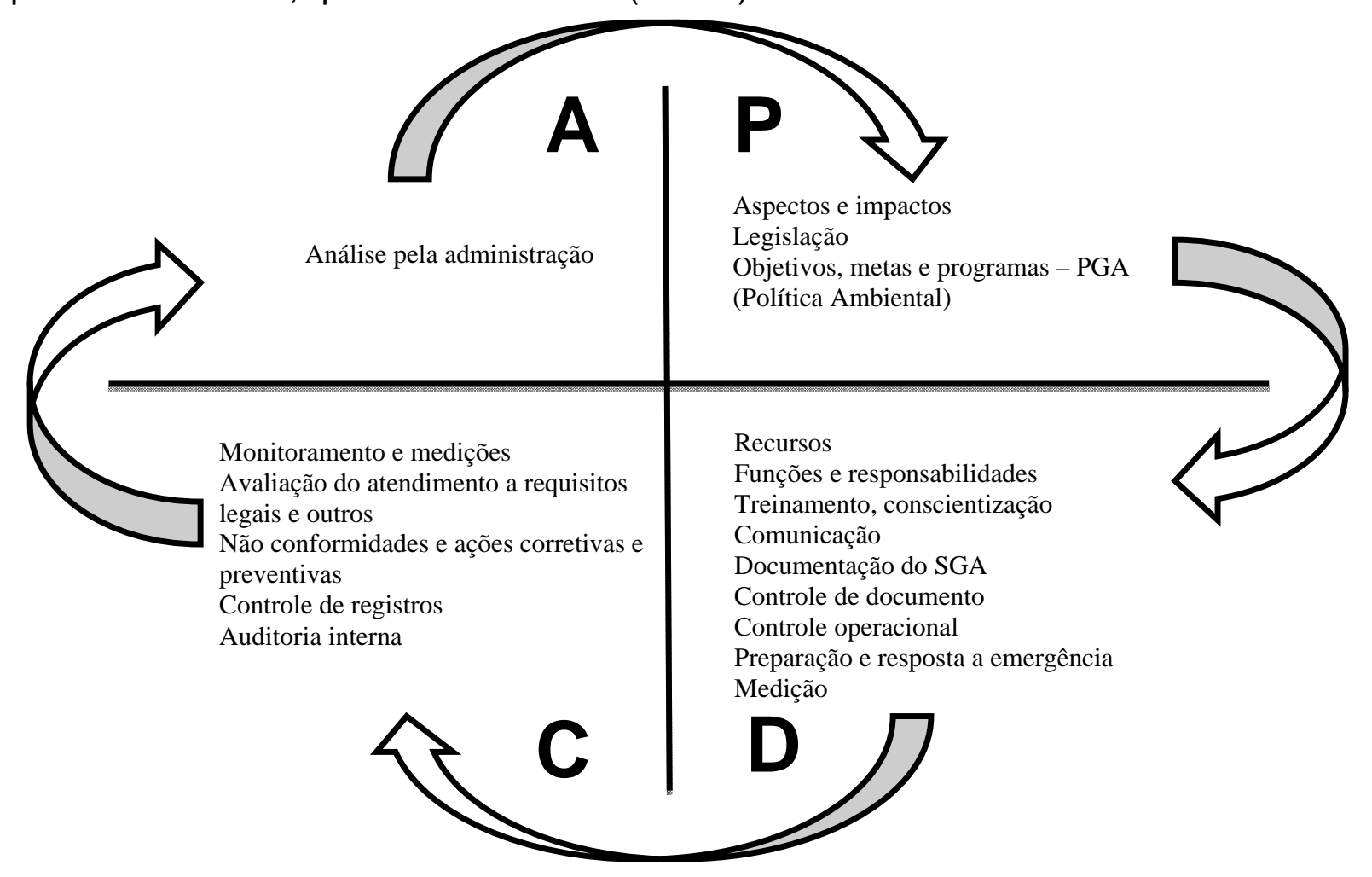

FIGURA 4 - Ciclo PDCA 
O ciclo PDCA, foi desenvolvido por Walter A. Shewhart na década de 20, mas começou a ser conhecido como ciclo de Deming em 1950 (DEMING, 1990), por ter sido amplamente difundido por este. É uma técnica simples que visa o controle do processo, podendo ser usado de forma contínua para o gerenciamento das atividades de uma organização.

O ciclo PDCA é um método que visa a controlar e conseguir resultados eficazes e confiáveis nas atividades de uma organização. É um eficiente modo de apresentar uma melhoria no processo. Padroniza as informações do controle da qualidade, evita erros lógicos nas análises, e torna as informações mais fáceis de entender. Pode também ser usado para facilitar a transição para o estilo de administração direcionada para melhoria contínua.

Este ciclo está composto em quatro fases básicas:

1) traçar um plano (PLAN)

Este passo é estabelecido com bases nas diretrizes da empresa. Quando traçamos um plano, temos três pontos importantes para considerar:

a- Estabelecer os objetivos, sobre os itens de controle.

b- Estabelecer o caminho para atingi-los.

c- Decidir quais os métodos a serem usados para consegui-los.

Após definidas estas metas e os objetivos, deve-se estabelecer uma metodologia adequada para atingir os resultados

2) executar o plano $(D O)$

Neste passo pode ser abordado em três pontos importantes:

a- Treinar no trabalho o método a ser empregado.

b- Executar o método.

c- Coletar os dados para verificação do processo.

Neste passo devem ser executadas as tarefas exatamente como estão previstas nos planos.

3) verificar os resultados (CHECK)

Neste passo, verificamos o processo e avaliamos os resultados obtidos:

a- Verificar se o trabalho está sendo realizado de acordo com o padrão.

b- Verificar se os valores medidos variaram, e comparar os resultados com o padrão. 
c- Verificar se os itens de controle correspondem com os valores dos objetivos.

4) fazer ações corretivamente (ACT)

Tomar ações baseadas nos resultados apresentados no passo 3.

a- Se o trabalho desviar do padrão, tomar ações para corrigir estes.

b- Se um resultado estiver fora do padrão, investigar as causas e tomar ações para prevenir e corrigi-lo.

c- Melhorar o sistema de trabalho e o método

Considerando os itens da Norma NBR 14001 (ABNT, 2004) e associados ao ciclo PDCA, pode-se resumir estes itens conforme a TAB. 2 abaixo:

TABELA 2 - A Norma NBR ISO 14.001 e o ciclo PDCA

\begin{tabular}{|c|c|c|c|}
\hline $1^{\mathrm{a}}$ Etapa & $2^{\mathrm{a}}$ Etapa & $3^{a}$ Etapa & $4^{\mathrm{a}}$ Etapa \\
\hline Planejar & Realizar & Verificar & Atuar \\
\hline $\begin{array}{l}\text { Comprometimento com a } \\
\text { Política Ambiental } \\
\text { Verificação do } \\
\text { Desempenho Ambiental } \\
\text { (diagnóstico/prognóstico } \\
\text { ambiental) } \\
\text { Elaboração do Plano de } \\
\text { Implementação do SGA } \\
\text { - Aspectos e impactos } \\
\text { ambientais } \\
\text { - Requisitos legais e } \\
\text { corporativos } \\
\text { - Objetivos e metas } \\
\text { - Plano de Ação e } \\
\text { Programa de Gestão } \\
\text { Ambiental }\end{array}$ & $\begin{array}{l}\text { Implementação e } \\
\text { Operacionalização } \\
\text { - Alocação de } \\
\text { Recursos } \\
\text { - Estrutura e } \\
\text { Responsabilidades } \\
\text { - Conscientização e } \\
\text { Treinamento } \\
\text { - Comunicações } \\
\text { - Documentação do } \\
\text { SGA } \\
\text { - Controle } \\
\text { Operacional e } \\
\text { Programas de } \\
\text { Gestão Específicos } \\
\text { - Resposta às } \\
\text { emergências }\end{array}$ & $\begin{array}{l}\text { Avaliação } \\
\text { Periódica } \\
\text { - Monitoramento } \\
\text { - Ações } \\
\text { Corretivas e } \\
\text { Preventivas } \\
\text { - Registros } \\
\text { - Auditorias do } \\
\text { Sistema de } \\
\text { Gestão }\end{array}$ & $\begin{array}{l}\text { Revisão e } \\
\text { análise } \\
\text { crítica do } \\
\text { Sistema de } \\
\text { Gestão } \\
\text { Ambiental }\end{array}$ \\
\hline
\end{tabular}

Os setores públicos, por atuarem, na maioria das vezes, sem concorrência, quando comparados às empresas privadas, são estimulados a implantarem um Sistema de Gestão Ambiental em suas unidades por setores responsáveis pelas questões ambientais à funcionários sensibilizados com as questões do meio ambiente, além do cumprimento das legislações ambientais. Os benefícios que um SGA traz para as empresas sejam elas públicas ou privadas, são percebidos 
na própria dinâmica da implantação, trazendo redução de custos, grandes benefícios ambientais e capacitação do recurso humano da empresa.

A implementação e o sucesso de um SGA, bem como a preservação do meio ambiente, dependem quase que exclusivamente do ser humano, seja em empresas, ou apenas o indivíduo como parte do ecossistema onde habita. 
A seguir são apresentados os resultados obtidos neste trabalho: a proposta de um Sistema de Gestão Ambiental para USEXA, com os diagramas, planilhas, diretrizes, justificativas e conceitos utilizados.

Procurou-se descrever neste trabalho as práticas já seguidas pelo CTMSP e USEXA, identificando aquelas que precisam de ajustes e/ou implementação para atender ao SGA, o que resultou na proposta de um sistema de gestão ambiental para USEXA apresentada a seguir.

Foi elaborado o documento sobre treinamento e conscientização para USEXA, com ênfase em gestão de pessoas, para atender ao item específico da Norma NBR ISO 14001 (APÊNDICE B) e o Manual de Gestão Ambiental da USEXA (APÊNDICE C), atendendo o item sobre documentação do SGA.

\subsection{Planejamento}

\subsubsection{Política Ambiental}

A política ambiental foi elaborada juntamente com os responsáveis pela USEXA, seguindo as recomendações da ABNT NBR ISO 14001 (ABNT, 2004). A Política Ambiental da USEXA é:

Produzir hexafluoreto de urânio para suprir as necessidades do Centro Tecnológico da Marinha em São Paulo elevando o nível de independência tecnológica do Brasil. Para tal assumimos compromisso com o cumprimento das legislações vigentes e melhoras constantes na área de segurança, saúde e proteção do meio ambiente, bem como o estabelecimento de procedimentos para a prevenção da poluição e atendimento aos objetivos e metas ambientais.

\subsubsection{Auditoria prognóstica - aspectos e impactos ambientais}

A primeira fase do trabalho consistiu em um "prognóstico" realizado, sobretudo, analisando-se o RPAS (CTMSP, 2001), de onde foram extraídas as informações para o levantamento dos aspectos e impactos ambientais, uma vez que a USEXA está em fase de montagem eletromecânica e comissionamento. Posteriormente, é necessário que o Gerente Ambiental da USEXA, designe um Grupo de Trabalho para revisar os processos mencionados em cada planilha, conforme a operação e modificações implementadas na Usina. 
Na FIG. 5 é apresentado o diagrama de blocos do processo de fabricação do $\mathrm{UF}_{6}$, indicando a sequência de operações, as entradas de recursos e materiais, que geralmente estão associados aos aspectos ambientais e as saídas, ou impactos ambientais associados. A FIG. 6 demonstra as unidades da USEXA destinadas ao apoio administrativo, tratamento de efluentes.

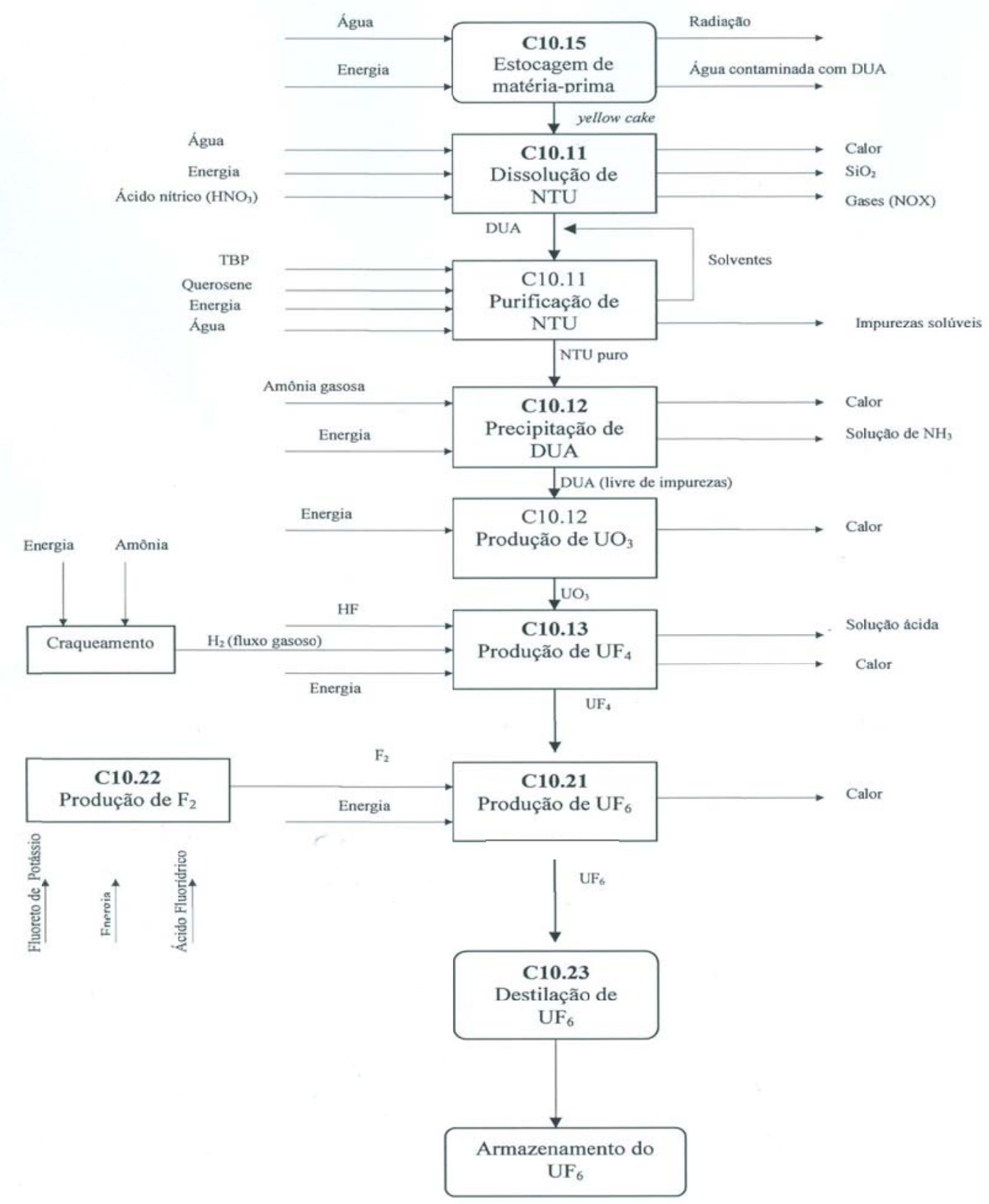

FIGURA 5 - Processo de fabricação de UF 6 

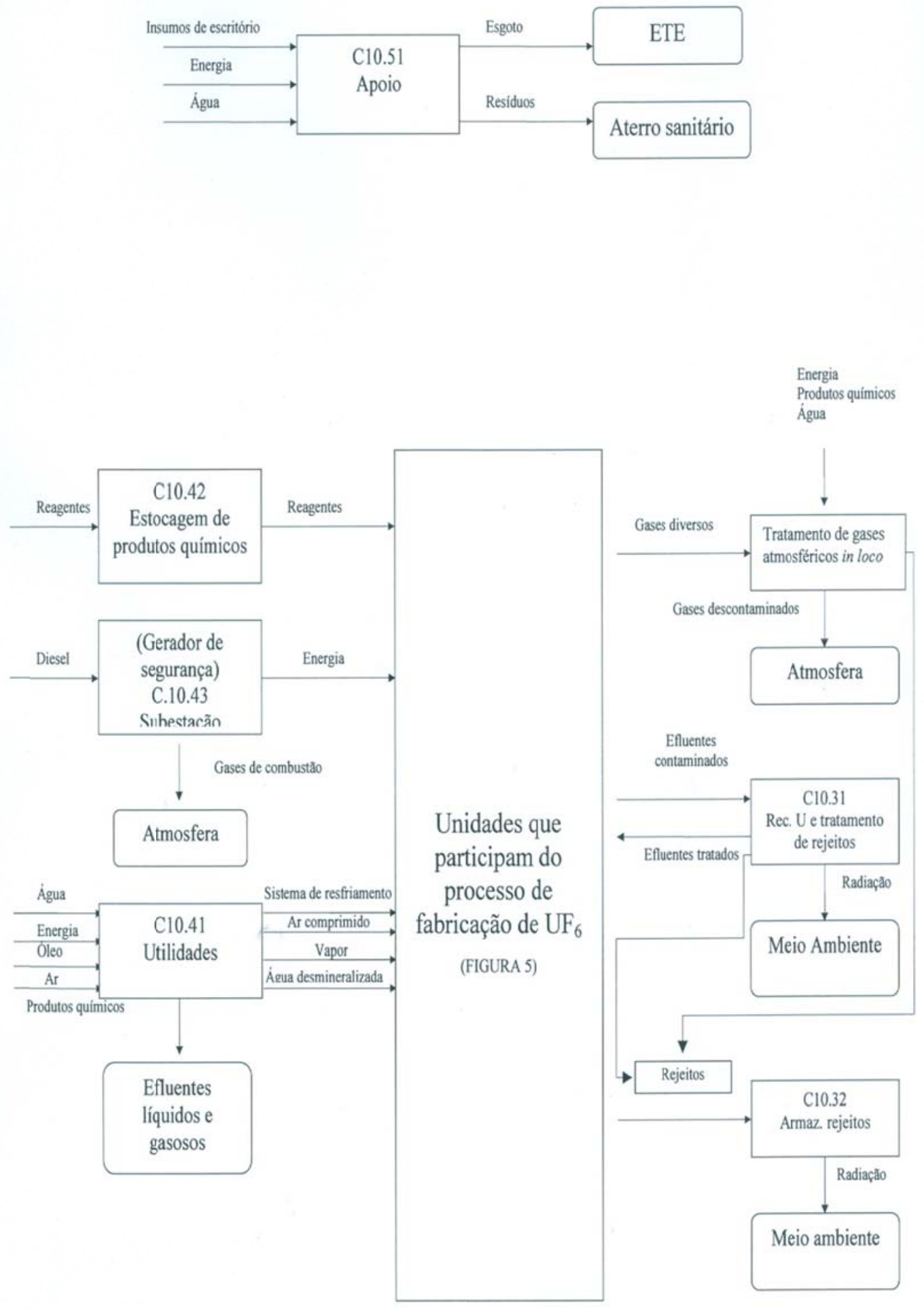

FIGURA 6 - Diagrama de entrada e saída das unidades que não estão diretamente envolvidas no processo de fabricação de $\mathrm{UF}_{6}$ 
A partir dos diagramas, foi identificada para cada unidade, a possível geração de efluentes, os resíduos sólidos, os rejeitos e as situações de risco (aspectos e impactos ambientais), utilizando-se o Procedimento $n^{\circ}$ PR-CTMSPSGA-01 - Identificação de Aspectos e Impactos Ambientais (CTMSP, 2003). Sempre que houver alteração no processo, acordos com as partes interessadas, mudança na legislação, nova licença, os aspectos e impactos ambientais deverão ser revistos para uma nova avaliação dessas informações.

Abaixo são apresentadas as TAB. 3 a 14 com os aspectos e impactos ambientais para cada unidade da USEXA. 
USEXA

TABELA 3 - LEVANTAMENTO DE ASPECTOS E IMPACTOS AMBIENTAIS - C10.11

Página: Abril de 2012 Rev.: 0

Elab. por: Mattiolo, S.R.

UNIDADE: C10 11 - PURIFICAÇÃO DE NITRATO DE URANILO (NTU)

DESCRIÇÃO DA ATIVIDADE/PROCESSO: Processos de dissolução, maturação, filtração e purificação do urânio a partir de yellow cake para obtenção do nitrato de uranilo (NTU) purificado.

Atividade I Processo/Equipamento

\begin{tabular}{l|l}
\hline Sala de Controle Local & Papel branco \\
Resíduo comum \\
Eletroeletrônicos \\
Lâmpadas fluorescentes \\
Pilhas/Baterias
\end{tabular}

Alteração da qualidade do solo Alteração da qualidade do solo Alteração da qualidade do solo Alteração da qualidade do solo Alteração da qualidade do solo Alteração da qualidade do solo e água Alteração da qualidade do ar Alteração da qualidade do solo Alteração da qualidade do solo e água Alteração da qualidade da água Alteração da qualidade do ar Alteração da qualidade do solo Alteração da qualidade do solo Alteração da qualidade do solo e água Alteração da qualidade do ar Alteração da qualidade do solo Alteração da qualidade da água Alteração da qualidade do solo e água Alteração da qualidade do solo e água, danos materiais, danos á saúde

Alteração da qualidade do solo e água Alteração da qualidade do solo Alteração da qualidade do solo e água

\begin{tabular}{|c|c|}
\hline $\begin{array}{c}\text { Caracterização } \\
\text { Normal (N) } \\
\text { Eventual (E) }\end{array}$ & Observações \\
\hline $\begin{array}{l}\mathrm{N} \\
\mathrm{N} \\
\mathrm{N} \\
\mathrm{N} \\
\mathrm{N}\end{array}$ & \\
\hline $\begin{array}{l}E \\
N \\
E\end{array}$ & $\begin{array}{l}\text { PEI - Plano de } \\
\text { Emergência } \\
\text { Ambiental }\end{array}$ \\
\hline $\begin{array}{l}\mathrm{E} \\
\mathrm{N} \\
\mathrm{N}\end{array}$ & C10.31 \\
\hline $\mathrm{N}$ & \\
\hline $\begin{array}{l}N \\
E \\
E\end{array}$ & C10.31 \\
\hline $\begin{array}{l}\mathrm{N} \\
\mathrm{N}\end{array}$ & C.10.31 \\
\hline $\begin{array}{l}E \\
E\end{array}$ & \\
\hline $\mathrm{N}$ & C.10.31 \\
\hline $\mathrm{N}$ & \\
\hline $\mathrm{N}$ & \\
\hline
\end{tabular}




\begin{tabular}{|c|c|c|c|c|}
\hline \multicolumn{3}{|c|}{ TABELA 4 - LEVANTAMENTO DE ASPECTOS E IMPACTOS AMBIENTAIS - C10.12 } & \multicolumn{2}{|c|}{$\begin{array}{l}\text { Página: Abril de } 2012 \\
\text { Rev.: } 0 \\
\text { Elab. por: Mattiolo, S.R. }\end{array}$} \\
\hline \multicolumn{5}{|c|}{ UNIDADE: C10 12 - PRODUÇÃO DE TRIÓXIDO DE URÂNIO (UO $\left.{ }_{3}\right)$} \\
\hline \multicolumn{5}{|c|}{$\begin{array}{l}\text { DESCRIÇÃO DA ATIVIDADE/PROCESSO: transformar o nitrato de uranilo (NTU) em diuranato de amônio }\left(\mathrm{NH}_{4}\right)_{2} \mathrm{U}_{2} \mathrm{O}_{7}(\mathrm{DUA}) \text { em } \mathrm{UO}_{3} .1 / 2 \mathrm{H}_{2} \mathrm{O} \text { vindo } \\
\text { da C10.11. }\end{array}$} \\
\hline Atividade / Processo/Equipamento & Aspecto ambiental & Impacto ambiental & $\begin{array}{l}\text { Caracterização } \\
\text { Normal (N) } \\
\text { Eventual (E) }\end{array}$ & Observações \\
\hline Sala de Controle Local & \begin{tabular}{|l|} 
Papel branco \\
Resíduo comum \\
Eletroeletrônicos \\
Lâmpadas fluorescentes \\
Pilhas/Baterias \\
\end{tabular} & $\begin{array}{l}\text { Alteração da qualidade do solo } \\
\text { Alteração da qualidade do solo } \\
\text { Alteração da qualidade do solo } \\
\text { Alteração da qualidade do solo } \\
\text { Alteração da qualidade do solo }\end{array}$ & $\begin{array}{l}\mathrm{N} \\
\mathrm{N} \\
\mathrm{N} \\
\mathrm{N} \\
\mathrm{N}\end{array}$ & \\
\hline Gerador & $\begin{array}{l}\text { Combustível - vazamento } \\
\text { Geração de gases } \\
\text { Peças usadas }\end{array}$ & $\begin{array}{l}\text { Alteração da qualidade do solo e água } \\
\text { Alteração da qualidade do ar } \\
\text { Alteração da qualidade do solo }\end{array}$ & $\begin{array}{l}E \\
N \\
E\end{array}$ & $\begin{array}{l}\text { PEI - Plano de } \\
\text { Emergência } \\
\text { Individual }\end{array}$ \\
\hline Sistema de Lavagem de Gases & $\begin{array}{l}\text { Efluentes industriais } \\
\text { Vapores } \\
\text { Radiação ionizante } \\
\text { Peças usadas }\end{array}$ & $\begin{array}{l}\text { Alteração da qualidade da água } \\
\text { Alteração da qualidade do ar } \\
\text { Danos à saúde dos trabalhadores e ao } \\
\text { meio ambiente } \\
\text { Alteração da qualidade do solo }\end{array}$ & $\begin{array}{l}\mathrm{N} \\
\mathrm{N} \\
\mathrm{N}\end{array}$ & C10.31 \\
\hline Adição de amônia gasosa $\left(\mathrm{NH}_{3}\right)$ & Vazamento & $\begin{array}{l}\text { Alteração na qualidade do ar } \\
\text { Saúde do Trabalhador }\end{array}$ & $\mathrm{E}$ & \\
\hline Filtro rotativo a vácuo & \begin{tabular}{|l|} 
Filtro saturado \\
Efluentes industriais
\end{tabular} & $\begin{array}{l}\text { Alteração da qualidade do solo } \\
\text { Alteração da qualidade da água }\end{array}$ & $\begin{array}{l}\mathrm{N} \\
\mathrm{N}\end{array}$ & C10.31 \\
\hline Calcinação & $\begin{array}{l}\text { Geração de calor } \\
\text { Geração de particulados }\end{array}$ & $\begin{array}{l}\text { Aumento do gasto energético } \\
\text { Alteração da qualidade do ar e solo }\end{array}$ & $\begin{array}{l}\mathrm{N} \\
\mathrm{E}\end{array}$ & \\
\hline $\begin{array}{l}\text { Tanque de coleta de pisos e um vaso de coleta } \\
\text { de drenos e transbordos }\end{array}$ & Efluentes/vazamento & Alteração da qualidade do solo e água & $\mathrm{E}$ & \\
\hline EPI & Descarte & Alteração da qualidade do solo & $\mathrm{N}$ & \\
\hline Produtos químicos: vencidos, embalagens, & Descarte & Alteração da qualidade do solo e água & $\mathrm{N}$ & \\
\hline
\end{tabular}




\begin{tabular}{|c|c|c|c|c|}
\hline \multicolumn{3}{|c|}{ TABELA 5 - LEVANTAMENTO DE ASPECTOS E IMPACTOS AMBIENTAIS - C10.13 } & \multicolumn{2}{|c|}{$\begin{array}{l}\text { Página: Abril de } 2012 \\
\text { Rev.: } 0 \\
\text { Elab.por: Mattiolo, S.R. }\end{array}$} \\
\hline \multicolumn{5}{|c|}{$\begin{array}{l}\text { UNIDADE: C10.13 - PRODUÇAO DE TETRAFLUORETO DE URANIO (UF4) } \\
\text { DESCRIÇÃO DA ATIVIDADE/PROCESSO: utilização do } \mathrm{UO}_{3} \cdot{ }^{1 / 2} \mathrm{H}_{2} \mathrm{O} \text {, proveniente da Unidade C10.12. Este transporte é realizado através do vaso transporte de } \\
\text { UO }_{3} \text {. }\end{array}$} \\
\hline Atividade /Processo/Equipamento & Aspecto ambiental & Impacto ambiental & $\begin{array}{l}\text { Caracterização } \\
\text { Normal (N) } \\
\text { Eventual (E) }\end{array}$ & Observações \\
\hline Sala de Controle Local & $\begin{array}{l}\text { Papel branco } \\
\text { Resíduo comum } \\
\text { Eletroeletrônicos } \\
\text { Lâmpadas fluorescentes } \\
\text { Pilhas/Baterias }\end{array}$ & $\begin{array}{l}\text { Alteração da qualidade do solo } \\
\text { Alteração da qualidade do solo } \\
\text { Alteração da qualidade do solo } \\
\text { Alteração da qualidade do solo } \\
\text { Alteração da qualidade do solo }\end{array}$ & $\begin{array}{l}\mathrm{N} \\
\mathrm{N} \\
\mathrm{N} \\
\mathrm{N} \\
\mathrm{N}\end{array}$ & \\
\hline Gerador & $\begin{array}{l}\text { Combustível - vazamento } \\
\text { Geração de gases } \\
\text { Peças usadas }\end{array}$ & $\begin{array}{l}\text { Alteração da qualidade do solo e água } \\
\text { Alteração da qualidade do ar } \\
\text { Alteração da qualidade do solo }\end{array}$ & $\begin{array}{l}\mathrm{E} \\
\mathrm{N} \\
\mathrm{E}\end{array}$ & \\
\hline Sistema de Lavagem de Gases & $\begin{array}{l}\text { Efluentes industriais } \\
\text { Vapores } \\
\text { Radiação ionizante }\end{array}$ & $\begin{array}{l}\text { Alteração da qualidade da água } \\
\text { Alteração da qualidade do ar } \\
\text { Danos à saúde dos trabalhadores e } \\
\text { meio ambiente }\end{array}$ & $\begin{array}{l}\mathrm{N} \\
\mathrm{N}\end{array}$ & C10.31 \\
\hline Reator de leito móvel; forno elétrico & Peças usadas & Alteração da qualidade do solo & E & \\
\hline Craqueamento da amônia $\left(\mathrm{NH}_{3}\right)$ & Geração hidrogênio $\left(\mathrm{H}_{2}\right)$ & Alteração da qualidade do ar & $\mathrm{N}$ & \\
\hline Injeções nitrogênio $\left(\mathrm{N}_{2}\right)$ & Produto químico - vazamento & Alteração da qualidade do solo e água & E & \\
\hline Entrada de fluoreto de hidrogênio (HF) & Produto químico - vazamento & Saúde dos trabalhadores & $E$ & \\
\hline Vaso de transporte e de pulmão de $\mathrm{UO}_{3}$ & $\begin{array}{l}\text { Vazamentos } \\
\text { Vasos rejeitados } \\
\text { Radiação ionizante }\end{array}$ & $\begin{array}{l}\text { Alteração da qualidade do solo, água e } \\
\text { ar e danos à saúde dos trabalhadores } \\
\text { Alteração da qualidade do solo } \\
\text { Danos à saúde dos trabalhadores e } \\
\text { meio ambiente }\end{array}$ & $\begin{array}{l}E \\
E \\
N\end{array}$ & \\
\hline EPI & Descarte & Alteração da qualidade do solo & $\mathrm{N}$ & \\
\hline Produtos químicos: vencidos, embalagens & Descarte & Alteração da qualidade do solo e água & $\mathrm{N}$ & \\
\hline
\end{tabular}




\begin{tabular}{|c|c|c|c|c|}
\hline \multicolumn{3}{|c|}{ TABELA 6 - LEVANTAMENTO DE ASPECTOS E IMPACTOS AMBIENTAIS - C10.15 } & \multicolumn{2}{|c|}{$\begin{array}{l}\text { Página: Abril de } 2012 \\
\text { Rev.: } 0 \\
\text { Elab. por: Mattiolo S.R }\end{array}$} \\
\hline \multicolumn{5}{|c|}{$\begin{array}{l}\text { UNIDADE: C10.15 - ESTOCAGEM DE MATÉRIA PRIMA } \\
\text { DESCRIÇÃO DA ATIVIDADE/PROCESSO: Recebimento e estocagem de yellow cake }\end{array}$} \\
\hline Atividade / Processo/Equipamento & Aspecto ambiental & Impacto ambiental & $\begin{array}{l}\text { Caracterização } \\
\text { Normal (N) } \\
\text { Eventual (E) }\end{array}$ & Observações \\
\hline Sala de Controle Local & $\begin{array}{l}\text { Papel branco } \\
\text { Resíduo comum } \\
\text { Eletroeletrônicos } \\
\text { Lâmpadas fluorescentes } \\
\text { Pilhas/Baterias }\end{array}$ & $\begin{array}{l}\text { Alteração da qualidade do solo } \\
\text { Alteração da qualidade do solo } \\
\text { Alteração da qualidade do solo } \\
\text { Alteração da qualidade do solo } \\
\text { Alteração da qualidade do solo }\end{array}$ & $\begin{array}{l}N \\
N \\
N \\
N \\
N\end{array}$ & \\
\hline Gerador & $\begin{array}{l}\text { Vazamento de combustível } \\
\text { Geração de gases } \\
\text { Peças usadas }\end{array}$ & $\begin{array}{l}\text { Alteração da qualidade do solo e água } \\
\text { Alteração da qualidade do ar } \\
\text { Alteração da qualidade do solo }\end{array}$ & $\begin{array}{l}E \\
N \\
E\end{array}$ & \\
\hline Equipamentos & Peças usadas & Alteração da qualidade do solo & $E$ & \\
\hline Tambores metálicos e paletes & $\begin{array}{l}\text { Vazamento } \\
\text { Descartados } \\
\text { Radiação ionizante } \\
\text { Efluentes (água de lavagem do } \\
\text { piso) }\end{array}$ & $\begin{array}{l}\text { Alteração da qualidade do solo e água } \\
\text { Alteração da qualidade do solo } \\
\text { Danos à saúde dos trabalhadores e } \\
\text { meio ambiente } \\
\text { Alteração da qualidade do solo e água }\end{array}$ & $\begin{array}{l}E \\
N \\
E \\
N \\
E\end{array}$ & \\
\hline Sistema de exaustão & Descarte de filtros & Alteração da qualidade do solo & $\mathrm{N}$ & \\
\hline EPI & Descarte & Alteração do solo & $\mathrm{N}$ & \\
\hline
\end{tabular}




\begin{tabular}{|c|c|c|c|c|}
\hline \multicolumn{3}{|c|}{ TABELA 7 - LEVANTAMENTO DE ASPECTOS E IMPACTOS AMBIENTAIS - C10.21 } & \multicolumn{2}{|c|}{$\begin{array}{l}\text { Página: Abril de } 2012 \\
\text { Rev.: } 0 \\
\text { Elab.por: Mattiolo, S.R. }\end{array}$} \\
\hline \multicolumn{5}{|c|}{ UNIDADE: C10.21 - PRODUÇÃO DE HEXAFLUORETO DE URÂNIO (UF6) E C10.23 - DESTILAÇÃO DE HEXAFLUORETO DE URÂNIO (UF6) } \\
\hline Atividade / Processo/Equipamento & Aspecto ambiental & Impacto ambiental & $\begin{array}{l}\text { Caracterização } \\
\text { Normal (N) } \\
\text { Eventual (E) }\end{array}$ & Observações \\
\hline Gerador & $\begin{array}{l}\text { Vazamento de combustível } \\
\text { Geração de gases }\end{array}$ & $\begin{array}{l}\text { Alteração da qualidade do solo e água } \\
\text { Alteração da qualidade do ar }\end{array}$ & $\begin{array}{l}\mathrm{E} \\
\mathrm{N}\end{array}$ & \\
\hline Sistema de Lavagem de Gases & $\begin{array}{l}\text { Vazamento de produto químico } \\
\text { Efluentes industriais } \\
\text { Vapores }\end{array}$ & $\begin{array}{l}\text { Alteração da qualidade do solo e água } \\
\text { Alteração da qualidade da água } \\
\text { Alteração da qualidade do ar }\end{array}$ & $\begin{array}{l}E \\
N \\
N\end{array}$ & C10.31 \\
\hline $\begin{array}{l}\text { Prédio sob pequena depressão, com } \\
\text { ventilação forçada }\end{array}$ & Vazamento & $\begin{array}{l}\text { Alteração da qualidade do ar e danos à } \\
\text { saúde dos trabalhadores }\end{array}$ & $E$ & \\
\hline Transporte $\mathrm{UF}_{4} \mathrm{p} / \mathrm{silos}$ e moegas & Vazamento & Alteração da qualidade do ar & $\mathrm{E}$ & \\
\hline $\begin{array}{l}\text { Transporte das cinzas }\left(\mathrm{UF}_{4} \text { não reagido }\right. \\
\left.\text { e } \mathrm{UO}_{2} \mathrm{~F}_{2}\right) \text {; uso de nitrogênio para ser } \\
\text { enviado para a unidade } \mathrm{C} 10.31\end{array}$ & $\begin{array}{l}\text { Vasos rejeitados } \\
\text { Vazamento de produtos químicos }\end{array}$ & $\begin{array}{l}\text { Alteração da qualidade do solo } \\
\text { Alteração da qualidade do solo e água }\end{array}$ & $\begin{array}{l}\mathrm{E} \\
\mathrm{E}\end{array}$ & \\
\hline Sistema de vácuo & Peças usadas & Alteração da qualidade do solo & $\mathrm{N}$ & \\
\hline $\begin{array}{l}\text { Transferência líquida por aquecimento } \\
\text { (cilindros 30B ou para a unidade } \\
\text { C10.23) }\end{array}$ & $\begin{array}{l}\text { Vazamento } \\
\text { Cilindros rejeitados }\end{array}$ & $\begin{array}{l}\text { Alteração da qualidade do solo e água } \\
\text { Alteração da qualidade do solo }\end{array}$ & $\begin{array}{l}\mathrm{N} \\
\mathrm{N}\end{array}$ & \\
\hline $\begin{array}{l}\text { Sistema de } \\
\text { solidificação } \\
\text { manual }\end{array}$ & $\begin{array}{l}\text { Radiação ionizante } \\
\text { Vazamento }\end{array}$ & $\begin{array}{l}\text { Danos a saúde do trabalhador e meio } \\
\text { ambiente } \\
\text { Alteração da qualidade do solo e água }\end{array}$ & $\begin{array}{l}E \\
E\end{array}$ & \\
\hline Produto químico - Flúor $\mathrm{F}_{2}$ & Vazamento - corrosão & $\begin{array}{l}\text { Alteração da qualidade do solo, água e } \\
\text { danos à saúde }\end{array}$ & $\mathrm{E}$ & \\
\hline EPI & Descarte & Alteração da qualidade do solo & $\mathrm{N}$ & \\
\hline $\begin{array}{l}\text { Produtos químicos: vencidos, } \\
\text { embalagens, }\end{array}$ & Descarte & Alteração da qualidade do solo & $\mathrm{N}$ & \\
\hline
\end{tabular}




\section{UNIDADE: C10.22 - PRODUÇÃO DE FLÚOR}

DESCRIÇÃO DA ATIVIDADE/PROCESSO: produz $\mathrm{F}_{2}$ utilizando o processo de eletrólise de um sal fundido (KF. $\left.2 \mathrm{HF}\right)$. O processo tem cinco etapas principais: preparo e transferência do eletrólito; condicionamento de eletrólito; eletrólise(produção de flúor); neutralização de flúor; e tratamento de efluentes gasosos.

\begin{tabular}{|c|c|c|c|c|}
\hline Atividade / Processo/Equipamento & Aspecto ambiental & Impacto ambiental & $\begin{array}{l}\text { Caracterização } \\
\text { Normal (N) } \\
\text { Eventual (E) }\end{array}$ & Observações \\
\hline $\begin{array}{l}\text { Sala de Controle Local (comum às unidades } \\
\text { C10.22, C1021 e C1023) }\end{array}$ & $\begin{array}{l}\text { Papel branco } \\
\text { Resíduo comum } \\
\text { Eletroeletrônicos } \\
\text { Lâmpadas fluorescentes } \\
\text { Pilhas/Baterias }\end{array}$ & $\begin{array}{l}\text { Alteração da qualidade do solo } \\
\text { Alteração da qualidade do solo } \\
\text { Alteração da qualidade do solo } \\
\text { Alteração da qualidade do solo } \\
\text { Alteração da qualidade do solo }\end{array}$ & $\begin{array}{l}\mathrm{N} \\
\mathrm{N} \\
\mathrm{N} \\
\mathrm{N} \\
\mathrm{N}\end{array}$ & \\
\hline $\begin{array}{l}\text { Preparo de eletrólito que receberá o HF- } \\
\text { reator }\end{array}$ & $\begin{array}{l}\text { Peças usadas } \\
\text { Vazamento de produto químico }\end{array}$ & $\begin{array}{l}\text { Alteração da qualidade do solo } \\
\text { Alteração da qualidade do solo e água }\end{array}$ & $\begin{array}{l}E \\
E\end{array}$ & \\
\hline Sistema de purga com $\mathrm{N}_{2}$ & $\begin{array}{l}\text { Vazamento de produto químico } \\
\text { Calor }\end{array}$ & $\begin{array}{l}\text { Alteração da qualidade do solo e água } \\
\text { Aumento do gasto energético }\end{array}$ & $\mathrm{E}$ & \\
\hline Adição de fluoreto de lítio( LiF) & Vazamento de produto químico & Alteração da qualidade do solo e água & $\mathrm{E}$ & \\
\hline $\begin{array}{l}\text { Transferência do eletrólito (tubos flexíveis, } \\
\text { vapor de água aquecido) }\end{array}$ & $\begin{array}{l}\text { Peças usadas } \\
\text { Vazamento } \\
\text { Calor }\end{array}$ & $\begin{array}{l}\text { Alteração da qualidade do solo } \\
\text { Alteração da qualidade do solo e água } \\
\text { Aumento do gasto energético }\end{array}$ & $\begin{array}{l}E \\
E \\
N\end{array}$ & \\
\hline Troca do filtro do eletrólito & Filtro saturado & Alteração da qualidade do solo & $\mathrm{N}$ & \\
\hline Sistema de Lavagem de gases de HF * & $\begin{array}{l}\text { Efluentes industriais } \\
\text { Vapores tóxicos } \\
\text { Explosões }\end{array}$ & $\begin{array}{l}\text { Alteração da qualidade do solo e água } \\
\text { Alteração da qualidade do ar e danos à } \\
\text { saúde dos trabalhadores e danos materiais }\end{array}$ & $\begin{array}{l}N \\
E\end{array}$ & C10.31 \\
\hline Sistema de ventilação & $\begin{array}{l}\text { Gases } \\
\text { Calor } \\
\text { Filtro saturado } \\
\end{array}$ & $\begin{array}{l}\text { Alteração da qualidade do ar } \\
\text { Aumento do gasto energético } \\
\text { Alteração da qualidade do solo }\end{array}$ & $\begin{array}{l}\mathrm{N} \\
\mathrm{N} \\
\mathrm{N}\end{array}$ & \\
\hline EPI & Descarte & Alteração da qualidade do solo & $\mathrm{N}$ & \\
\hline Produtos químicos: vencidos, embalagens, & Descarte & Alteração da qualidade do solo & $\mathrm{N}$ & \\
\hline
\end{tabular}




\begin{tabular}{|c|c|c|c|c|}
\hline \multicolumn{3}{|c|}{ TABELA 9 - LEVANTAMENTO DE ASPECTOS E IMPACTOS AMBIENTAIS - C10.31 } & \multicolumn{2}{|c|}{$\begin{array}{l}\text { Abril de } 2012 \\
\text { Rev.: } 0 \\
\text { Elab.por: Mattiolo, S.R. }\end{array}$} \\
\hline \multicolumn{5}{|c|}{$\begin{array}{l}\text { UNIDADE: C10.31- RECUPERAÇÃO DE URÂNIO E TRATAMENTO DE REJEITOS - Prédio I } \\
\text { DESCRIÇÃO DA ATIVIDADE/PROCESSO: responsável pela recuperação de urânio e tratamento de todos os rejeitos/efluentes líquidos e sólidos } \\
\text { gerados }\end{array}$} \\
\hline Atividade / Processo/Equipamento & Aspecto ambiental & Impacto ambiental & $\begin{array}{l}\text { Caracterização } \\
\text { Normal(N) } \\
\text { Eventual(E) }\end{array}$ & Observações \\
\hline $\begin{array}{l}\text { Seção de recuperação de urânio na forma de } \\
\text { solução de nitrato de uranilo (NTU) para a } \\
\text { Unidade C10.11 } \\
\text { - Tratamento e regeneração das soluções de } \\
\left.\text { carbonato de potássio ( } \mathrm{K}_{2} \mathrm{CO}_{3}\right) \text {; tratamento das } \\
\text { soluções de carbonato de sódio; recuperação de } \\
\text { solvente; filtrado é enviado à seção de } \\
\text { tratamento de rejeitos para a eliminação de } \\
\text { urânio }\end{array}$ & $\begin{array}{l}\text { Vazamento de produto } \\
\text { químico } \\
\text { Radiação ionizante } \\
\text { Efluentes químicos } \\
\text { Vapores } \\
\text { Calor } \\
\text { Filtro saturado e peças } \\
\text { usadas }\end{array}$ & $\begin{array}{l}\text { Alteração da qualidade do solo e água } \\
\text { Danos a saúde dos trabalhadores e ao } \\
\text { meio ambiente } \\
\text { Alteração da qualidade da água } \\
\text { Alteração da qualidade do ar } \\
\text { Aumento do gasto energético } \\
\text { Alteração da qualidade do solo }\end{array}$ & $\begin{array}{l}\mathrm{E} \\
\mathrm{N} \\
\mathrm{N} \\
\mathrm{N} \\
\mathrm{N} \\
\mathrm{E}\end{array}$ & \\
\hline $\begin{array}{l}\text { Seção de tratamento de rejeitos e efluentes } \\
\text { a) Precipitação e filtração das substâncias } \\
\text { radioativas } \\
\text { tratamento em batelada; mistura dos diversos } \\
\text { rejeitos; estocagem de filtrado da precipitação } \\
\text { para evaporação e imobilização, juntamente } \\
\text { com o rejeito oriundo da C10.41; a torta e auxiliar } \\
\text { de filtração é armazenada em tambores para } \\
\text { imobilização. O rejeito sólido centrifugado é } \\
\text { raspado e encaminhado para imobilização; b) } \\
\text { Imobilização do rejeito radiativo sólido gerado na } \\
\text { precipitação e filtração(C10.32/Estoc. Intermed. } \\
\text { de Rejeitos); c) compactação de rejeitos sólidos } \\
\text { em prensa pneumática (C10.32); tambores; } \\
\text { transporte para estocagem temporária. }\end{array}$ & $\begin{array}{l}\text { Vazamento de produto } \\
\text { químico } \\
\text { Radiação ionizante } \\
\text { Filtro saturado } \\
\text { Tambores inutilizados } \\
\text { Calor (evaporador) } \\
\text { Vazamento de combustível } \\
\text { Gases } \\
\text { Peças usadas }\end{array}$ & $\begin{array}{l}\text { Alteração da qualidade do solo e água } \\
\text { Danos a saúde dos trabalhadores e ao } \\
\text { meio ambiente } \\
\text { Alteração da qualidade do solo } \\
\text { Alteração da qualidade do solo } \\
\text { Aumento do gasto energético } \\
\text { Alteração da qualidade do solo e água } \\
\text { Alteração da qualidade do ar } \\
\text { Alteração da qualidade do solo }\end{array}$ & $\begin{array}{l}E \\
N \\
E \\
E \\
E \\
E \\
E \\
E\end{array}$ & \\
\hline EPI & Descarte & Alteração da qualidade do solo & $\mathrm{N}$ & \\
\hline Produtos químicos: vencidos, embalagens & Descarte & Alteração da qualidade do solo e água & $\mathrm{N}$ & \\
\hline
\end{tabular}




\begin{tabular}{|c|c|c|c|c|}
\hline \multicolumn{3}{|c|}{ TABELA 10 - LEVANTAMENTO DE ASPECTOS E IMPACTOS AMBIENTAIS - C10.32 } & \multicolumn{2}{|c|}{$\begin{array}{l}\text { Abril de } 2012 \\
\text { Rev.: } 0 \\
\text { Elab. por: Mattiolo, SR }\end{array}$} \\
\hline \multicolumn{5}{|c|}{ UNIDADE: C10.32 - ARMAZENAMENTO INICIAL DE REJEITOS DA USEXA } \\
\hline \multicolumn{5}{|c|}{ DESCRIÇÃO DA ATIVIDADE/PROCESSO: Armazenamento inicial de rejeitos da USEXA } \\
\hline Atividade / Processo/Equipamento & Aspecto & Impacto & $\begin{array}{c}\text { Caracterização } \\
\text { Normal (N) } \\
\text { Eventual (E) } \\
\end{array}$ & Observações \\
\hline Tambores & Descartados & Alteração da qualidade do solo & $\mathrm{E}$ & \\
\hline Concretagem & $\begin{array}{l}\text { Particulados de cimento } \\
\text { Embalagens }\end{array}$ & $\begin{array}{l}\text { Alteração da qualidade do ar e danos à saúde } \\
\text { Alteração da qualidade do solo }\end{array}$ & $\begin{array}{l}\mathrm{N} \\
\mathrm{N}\end{array}$ & \\
\hline Equipamentos & Peças usadas & Alteração da qualidade do solo & $\mathrm{E}$ & \\
\hline EPI & Descarte & Alteração da qualidade do solo & $\mathrm{N}$ & \\
\hline Rejeitos & Radiação ionizante & Danos à saúde dos trabalhadores e meio ambiente & $\mathrm{N}$ & \\
\hline
\end{tabular}




\section{USEXA}

TABELA

UNIDADE: C10.41 - UTILIDADES

DESCRIÇÃO DA ATIVIDDE/PROCESSO: As funções desta unidade são as de preparar, estocar e fornecer adequadamente as utilidades necessárias à operação da USEXA. Abrange os seguintes sistemas: sistema de água desmineralizada; sistema de água de resfriamento; sistema de ar comprimido: ar de processo, industrial e de instrumentos; sistema de água tratada, água potável e de efluentes; e sistema de geração de vapor.

\begin{tabular}{|c|c|c|c|c|}
\hline Atividade / Processo/Equipamento & Aspecto ambiental & Impacto ambiental & $\begin{array}{c}\text { Caracterizaç } \\
\text { ão } \\
\text { Normal (N) } \\
\text { Eventual (E) }\end{array}$ & Observações \\
\hline Sala de Controle Local & \begin{tabular}{|l|} 
Papel branco \\
Resíduo comum \\
Eletroeletrônicos \\
Lâmpadas fluorescentes \\
Pilhas/Baterias
\end{tabular} & $\begin{array}{l}\text { Alteração da qualidade do solo } \\
\text { Alteração da qualidade do solo } \\
\text { Alteração da qualidade do solo } \\
\text { Alteração da qualidade do solo } \\
\text { Alteração da qualidade do solo }\end{array}$ & $\begin{array}{l}\mathrm{N} \\
\mathrm{N} \\
\mathrm{N} \\
\mathrm{N} \\
\mathrm{N}\end{array}$ & \\
\hline Equipamentos diversos & $\begin{array}{l}\text { Vazamento de produto } \\
\text { químico } \\
\text { Peças usadas } \\
\text { Filtros saturados } \\
\text { Gases }\end{array}$ & $\begin{array}{l}\text { Alteração da qualidade do solo e água } \\
\text { Alteração da qualidade do solo } \\
\text { Alteração da qualidade do solo } \\
\text { Alteração da qualidade do ar }\end{array}$ & $\begin{array}{l}E \\
E \\
N \\
N\end{array}$ & \\
\hline Caldeira geradora de vapor & Calor & Aumento do gasto energético & $\mathrm{N}$ & \\
\hline $\begin{array}{l}\text { Filtro de óleo combustível aquecido/ } \\
\text { aquecedor }\end{array}$ & $\begin{array}{l}\text { Filtro saturado } \\
\text { Vazamento de óleo } \\
\text { Calor }\end{array}$ & $\begin{array}{l}\text { Alteração da qualidade do solo } \\
\text { Alteração da qualidade do solo e água } \\
\text { Aumento do gasto energético }\end{array}$ & $\begin{array}{l}\mathrm{N} \\
\mathrm{E} \\
\mathrm{N}\end{array}$ & $\begin{array}{l}\text { Plano de } \\
\text { Emergência } \\
\text { Individual - } \\
\text { PEI }\end{array}$ \\
\hline Óleo combustível & $\begin{array}{l}\text { Vazamento } \\
\text { Gases }\end{array}$ & $\begin{array}{l}\text { Alteração da qualidade do solo e água } \\
\text { Alteração da qualidade do ar }\end{array}$ & $\begin{array}{l}\mathrm{E} \\
\mathrm{N}\end{array}$ & \\
\hline EPI & Descarte & Alteração da qualidade do solo & $\mathrm{N}$ & \\
\hline $\begin{array}{l}\text { Produtos químicos: vencidos, } \\
\text { embalagens, }\end{array}$ & Descarte & Alteração da qualidade do solo e água & $\mathrm{N}$ & \\
\hline
\end{tabular}

Abril de 2012

Rev.: 0

Elab.por: Mattiolo, S.R. 
USEXA

TABELA 12 - LEVANTAMENTO DE ASPECTOS E IMPACTOS AMBIENTAIS - C10.42

Abril de 2012

Rev.: 0

Elab. por: Mattiolo SR

\section{UNIDADE: C10.42 - ESTOCAGEM DE PRODUTOS QUÍMICOS}

DESCRIÇÃO DA ATIVIDADE/PROCESSO: Recebimento, estocagem e transferência dos diversos produtos químicos consumidos nas unidades da USEXA. Está dividida em duas subunidades: estocagem de produtos químicos embalados; e estocagem de produtos químicos líquidos a granel.

\begin{tabular}{|c|c|c|c|c|}
\hline $\begin{array}{l}\text { Atividade I } \\
\text { Processo/Equipamento }\end{array}$ & Aspecto ambiental & Impacto ambiental & $\begin{array}{l}\text { Caracterização } \\
\text { Normal (N) } \\
\text { Eventual (E) }\end{array}$ & Observações \\
\hline \multicolumn{5}{|c|}{ Produtos químicos embalados } \\
\hline $\begin{array}{l}\text { Sólidos, líquidos corrosivos e } \\
\text { inflamáveis }\end{array}$ & $\begin{array}{l}\text { Gases } \\
\text { Vazamento } \\
\text { Explosões, incêndio }\end{array}$ & $\begin{array}{l}\text { Alteração da qualidade do ar } \\
\text { Alteração da qualidade do solo e água } \\
\text { Danos materiais e à saúde (inclusive trabalhadores externos) }\end{array}$ & $\begin{array}{l}E \\
E \\
E\end{array}$ & \\
\hline & & Alteração da qualidade da água & $E$ & C10.31 \\
\hline \multicolumn{5}{|c|}{ Produtos líquidos a granel - estocagem e transferência } \\
\hline Painel de controle & $\begin{array}{l}\text { Peças usadas } \\
\text { Resíduo comum }\end{array}$ & $\begin{array}{l}\text { Alteração da qualidade do solo } \\
\text { Alteração da qualidade do solo }\end{array}$ & $\begin{array}{l}\mathrm{N} \\
\mathrm{N}\end{array}$ & \\
\hline Transporte dos produtos & $\begin{array}{l}\text { Gases } \\
\text { Colisões do veículo } \\
\text { Ruído } \\
\text { Vazamento }\end{array}$ & $\begin{array}{l}\text { Alteração da qualidade do ar } \\
\text { Alteração da qualidade do solo e da água e danos à saúde } \\
\text { Danos à saúde } \\
\text { Danos à saúde do trabalhador e ao meio ambiente }\end{array}$ & $\begin{array}{l}E \\
E \\
N \\
E\end{array}$ & \\
\hline $\begin{array}{l}\text { Prédio coberto, sem fecham. } \\
\text { lateral: } \\
\text { Fluoreto de hidrogênio(HF) }\end{array}$ & Vazamento & $\begin{array}{l}\text { Alteração da qualidade do solo, água, ar, danos à saúde dos } \\
\text { trabalhadores }\end{array}$ & $\mathrm{E}$ & \\
\hline $\begin{array}{l}\text { Céu aberto: Amônia líquida } \\
\left(\mathrm{NH}_{3}\right) \text {; Ácido nítrico }\left(\mathrm{HNO}_{3}\right) \text {; } \\
\text { Nitrogênio líquido }\left(\mathrm{N}_{2}\right) ; \\
\text { Hidróxido de sódio }(\mathrm{NaOH}) ; \\
\text { Hidróxido de potássio }(\mathrm{KOH})\end{array}$ & Vazamento & $\begin{array}{l}\text { Alteração da qualidade do solo, água, ar, danos à saúde dos } \\
\text { trabalhadores }\end{array}$ & $\mathrm{E}$ & \\
\hline EPI & Descarte & Alteração da qualidade do solo & $\mathrm{N}$ & \\
\hline $\begin{array}{l}\text { Produtos químicos: vencidos, } \\
\text { embalagens, }\end{array}$ & Descarte & Alteração da qualidade do solo & $\mathrm{N}$ & \\
\hline
\end{tabular}




\begin{tabular}{|c|c|c|c|c|c|}
\hline USEXA & \multicolumn{3}{|c|}{ TABELA 13 - LEVANTAMENTO DE ASPECTOS E IMPACTOS AMBIENTAIS - C10.43 } & \multicolumn{2}{|c|}{$\begin{array}{l}\text { Abril de } 2012 \\
\text { Rev.: } 1 \\
\text { Elab.por: Mattiolo, S.R. }\end{array}$} \\
\hline \multicolumn{6}{|c|}{ UNIDADE: C10.43 - SUBESTAÇÃO } \\
\hline \multicolumn{6}{|c|}{ DESCRIÇÃO DA ATIVIDADE/PROCESSO: Estação secundária - transformação e distribuição da corrente elétrica } \\
\hline \multicolumn{2}{|c|}{ Atividade / Processo/Equipaemnto } & Aspecto ambiental & Impacto ambiental & $\begin{array}{l}\text { Caracterização } \\
\text { Normal (N) } \\
\text { Eventual (E) }\end{array}$ & Observações \\
\hline \multicolumn{2}{|c|}{ Equipamentos } & Peças usadas & Alteração da qualidade do solo & $\mathrm{E}$ & \\
\hline \multicolumn{2}{|l|}{ Gerador } & $\begin{array}{l}\text { Vazamento de combustível } \\
\text { Calor } \\
\text { Ruído } \\
\text { Gases }\end{array}$ & $\begin{array}{l}\text { Alteração da qualidade do solo e água } \\
\text { Aumento do gasto energético } \\
\text { Danos à saúde } \\
\text { Alteração da qualidade do ar }\end{array}$ & $\begin{array}{l}E \\
N \\
N \\
N\end{array}$ & $\begin{array}{l}\text { Caixa de } \\
\text { contenção - } \\
\text { PEI }\end{array}$ \\
\hline \multicolumn{2}{|l|}{ EPI } & Descarte & Alteração da qualidade do solo & $\mathrm{N}$ & \\
\hline USEXA & TABELA $1<$ & 4 - LEVANTAMENTO DE ASF & CTOS E IMPACTOS AMBIENTAIS - C10.51 & \multicolumn{2}{|c|}{$\begin{array}{l}\text { Abril de } 2012 \\
\text { Rev.: } 1 \\
\text { Elab.por: Mattiolo, S.R. }\end{array}$} \\
\hline \multicolumn{4}{|c|}{ UNIDADE: C10.51 - APOIO } & & \\
\hline \multicolumn{2}{|c|}{ Atividade I Processo/Equipamento } & Aspecto ambiental & Impacto ambiental & $\begin{array}{l}\text { Caracterização } \\
\text { Normal (N) } \\
\text { Eventual (E) }\end{array}$ & Observações \\
\hline \multicolumn{2}{|c|}{$\begin{array}{l}\text { Salas administrativas/ projeto/sala de } \\
\text { estudo }\end{array}$} & $\begin{array}{l}\text { Papel branco } \\
\text { Resíduo comum } \\
\text { Eletroeletrônicos } \\
\text { Lâmpadas fluorescentes } \\
\text { Pilhas/Baterias } \\
\end{array}$ & $\begin{array}{l}\text { Alteração da qualidade do solo } \\
\text { Alteração da qualidade do solo } \\
\text { Alteração da qualidade do solo } \\
\text { Alteração da qualidade do solo } \\
\text { Alteração da qualidade do solo e água }\end{array}$ & $\begin{array}{l}N \\
N \\
N \\
N \\
N\end{array}$ & \\
\hline \multicolumn{2}{|c|}{ Ar condicionado } & Consumo de energia & Diminuição de recursos naturais & $\mathrm{N}$ & \\
\hline \multicolumn{2}{|l|}{ Copa } & $\begin{array}{l}\text { Resíduos recicláveis } \\
\text { Resíduos orgânicos }\end{array}$ & $\begin{array}{l}\text { Alteração da qualidade do solo } \\
\text { Alteração da qualidade do solo }\end{array}$ & $\begin{array}{l}\mathrm{N} \\
\mathrm{N}\end{array}$ & \\
\hline \multicolumn{2}{|l|}{ Sanitários } & Esgoto & Alteração da qualidade do solo & $\mathrm{N}$ & \\
\hline \multicolumn{2}{|l|}{ Água } & Consumo de recurso natural & Diminuição de recurso natural & $\mathrm{N}$ & \\
\hline
\end{tabular}




\subsubsection{Requisitos legais}

Foram verificadas as principais legislações federais e estaduais e normas aplicáveis às atividades desenvolvidas pela USEXA, incluindo as Normas da Comissão Nacional de Energia Nuclear - CNEN e Associação Brasileira de Normas Técnicas - ABNT e recomendações da Agência Internacional de Energia Atômica - AIEA. Foi utilizado o Procedimento $n^{\circ}$ PR-CTMSP-SGA-03_00 Identificação de Requisitos Legais (CTMSP, 2004). As principais legislações e normas estão elencadas no APÊNDICE A.

A USEXA mantém sistemática para a identificação e acesso à legislação ambiental aplicável, incluindo as NORTAM e NBR emitidas pela Diretoria de Portos e Costas - DPC e a Associação Brasileira de Normas Técnicas, respectivamente. A USEXA, por meio de empresa especializada que fornece um banco de dados contendo toda a legislação ambiental, manterá cópia na íntegra dos textos aplicáveis às suas atividades, avaliando sua aplicabilidade, e assegurando o gerenciamento do novo diploma, definindo ações e responsáveis para atendimento de novos requisitos.

\subsubsection{Avaliação dos impactos ambientais}

Após a identificação dos aspectos e impactos ambientais, a fase subsequente foi avaliar o que foi identificado. Este processo foi realizado em planilhas de avaliação dos impactos ambientais para cada unidade da USEXA.

Estas planilhas permitem priorizar os impactos ambientais, e assim definir os objetivos, metas e os programas específicos, além dos já estabelecidos na Política Ambiental, quantificando itens como gravidade, abrangência, frequência/probabilidade e requisitos legais, normas técnicas e outros.

Nesta avaliação foi utilizada como base a planilha proposta no Procedimento PR-CTMSP-SGA-02_00 - Avaliação dos Impactos Ambientais (CTMSP, 2003a) e após análise desta planilha foi proposta a inclusão de mais um item para compor o filtro de significância. A adição deste filtro permite considerar a localização do empreendimento na avaliação de impacto.

Abaixo seguem os critérios utilizados na avaliação do impacto, sendo atribuídos graus conforme discriminados abaixo: 


\section{Gravidade:}

Baixa (B) - impacto de magnitude desprezível, totalmente reversível com ações imediatas

Média (M) - impacto de magnitude considerável, reversível com ações Mitigadoras

Alta (A) - impacto de grande magnitude, com consequências irreversíveis mesmo com ações mitigadoras.

$$
\begin{array}{lll}
\mathrm{B} & - & 1 \mathrm{a} 3 \text { pontos } \\
\mathrm{M} & - & 4 \mathrm{a} 6 \text { pontos } \\
\mathrm{A} & - & 7 \text { a } 9 \text { pontos }
\end{array}
$$

\section{Abrangência:}

Baixa (B) - impacto restrito ao local da ocorrência

Média (M) - impacto que extrapola o local da ocorrência, mas que permanece dentro dos limites da OM - Organização Militar

Alta (A) - $\quad$ impacto que extrapola os limites do CTMSP

B $\quad$ - 3 pontos

M $\quad-\quad 6$ pontos

A $\quad-\quad 9$ pontos

\section{Frequência/Probabilidade:}

Baixa (B) - impacto não é esperado ocorrer, embora haja alguma expectativa

Média $(M)$ - impacto é esperado ocorrer algumas vezes

Alta $(A)$ - impacto é esperado ocorrer várias vezes

\section{Filtros de significância:}

- Requisitos legais, normas técnicas e outros

Quando o aspecto ou impacto considerado contrariar algum dispositivo legal ou norma prevista, nas esferas federal, estadual ou municipal, referente ao meio ambiente.
Atende
- 1 ponto
Não atende
- 9 pontos 
- Localização do empreendimento

$\begin{array}{lll}\text { CEA } & - & 3 \text { pontos } \\ \text { Sede } & - & 1 \text { ponto }\end{array}$

A introdução da localização do empreendimento no filtro de significância foi proposta por MATTIOLO et al (2011), possibilitando a priorização dos impactos do CTMSP (Sede e CEA).

O CEA está localizado em área rural e contígua à FLONA - Floresta Nacional Ipanema, município de Iperó - SP e a Sede está localizada em São Paulo, Capital em área urbana. As legislações para área rural são mais restritivas do que as de área urbana. A utilização do filtro de significância, quanto à localização, permite que o grau de significância dos impactos da Sede sejam diferentes do CEA.

As FIG. 7 e 8 exemplificam a importância da pontuação diferenciada da localização do empreendimento, permitindo a comparação de um mesmo impacto na CEA e na Sede e a observação da diferença do grau de significância.

Assim fica evidenciado que o CEA por estar próximo a uma área rural e o corpo receptor deste efluente ser Classe II - com parâmetros de liberação mais restritivos, como apresentados na Resolução CONAMA n 357 (CONAMA, 2005), o impacto deve ter grau de significância diferente e mais restritivo.

\section{Resultado Parcial}

O resultado da avaliação deve ser obtido por meio da soma dos graus atribuídos à gravidade e abrangência e multiplicados pela frequência/probabilidade.

\section{Resultado da Avaliação}

O resultado da avaliação deve ser obtido pela soma dos filtros de significância (requisitos legais, normas técnicas e outros e a localização do empreendimento). 
AVALIAÇÃO DE IMPACTOS - USEXA

\begin{tabular}{|c|c|c|c|c|c|c|c|c|c|}
\hline \multicolumn{2}{|c|}{ C10 12 - PRODUÇÃO DE TRIÓXIDO DE URÂNIO ( $\left(\mathrm{UO}_{3}\right)$} & \multicolumn{2}{|c|}{ Data: } & & \multicolumn{2}{|c|}{ Folha: } & \multicolumn{2}{|c|}{ Elaborado por: } & \multirow[b]{2}{*}{ Grau de Significância } \\
\hline & & \multicolumn{3}{|c|}{ Avaliação } & & \multicolumn{2}{|c|}{$\begin{array}{c}\text { Filtro de } \\
\text { Significância }\end{array}$} & $\begin{array}{l}\text { Resultado } \\
\text { da } \\
\text { Avaliacão }\end{array}$ & \\
\hline Aspecto & Impacto & 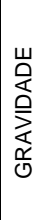 & 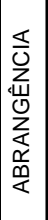 & 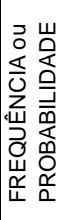 & 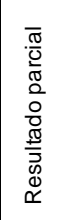 & 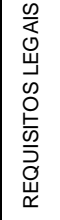 & 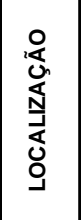 & & \\
\hline Vazamento - Amônia & Contaminação do ar & 3 & 3 & 1 & 6 & 1 & 3 & 24 & ALTO \\
\hline Urânio & Radiação ionizante & 3 & 2 & 1 & 5 & 1 & 3 & 20 & MÉDIO \\
\hline Efluentes industriais & Contaminação do solo & 2 & 1 & 1 & 3 & 1 & 3 & 12 & MÉDIO \\
\hline & Contaminação da água & 2 & 1 & 1 & 3 & 1 & 3 & 12 & MÉDIO \\
\hline Filtro contaminado & Contaminação do solo & 1 & 1 & 1 & 2 & 1 & 3 & 8 & BAIXO \\
\hline Rejeito & Contaminação do solo & 3 & 1 & 1 & 4 & 1 & 3 & 16 & MÉDIO \\
\hline
\end{tabular}

FIGURA 7 - Exemplo de Planilha de Avaliação de Impactos Ambientais no CEA

AVALIAÇÃO DE IMPACTOS - USEXA

\begin{tabular}{|c|c|c|c|c|c|c|c|c|c|}
\hline \multicolumn{2}{|c|}{ C10 12 - PRODUÇÃO DE TRIÓXIDO DE URÂNIO $\left(\mathrm{UO}_{3}\right)$} & \multicolumn{2}{|c|}{ Data: } & & \multicolumn{2}{|c|}{ Folha: } & \multicolumn{2}{|c|}{ Elaborado por: } & \multirow{3}{*}{ Grau de Significância } \\
\hline & & \multicolumn{3}{|c|}{ Avaliação } & & \multicolumn{2}{|c|}{$\begin{array}{c}\text { Filtro de } \\
\text { Significância }\end{array}$} & \begin{tabular}{|c} 
Resultado \\
da \\
Avaliacão
\end{tabular} & \\
\hline Aspecto & Impacto & 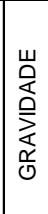 & 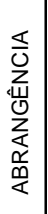 & 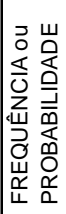 & 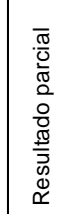 & 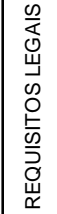 & 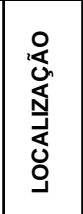 & & \\
\hline Vazamento - Amônia & Contaminação do ar & 3 & 3 & 1 & 6 & 1 & 1 & 12 & MÉDIO \\
\hline Urânio & Radiação ionizante & 3 & 2 & 1 & 5 & 1 & 1 & 10 & BAIXO \\
\hline Efluentes industriais & Contaminação do solo & 2 & 1 & 1 & 3 & 1 & 1 & 6 & BAIXO \\
\hline & Contaminação da água & 2 & 1 & 1 & 3 & 1 & 1 & 6 & BAIXO \\
\hline Filtro contaminado & Contaminação do solo & 1 & 1 & 1 & 2 & 1 & 1 & 4 & BAIXO \\
\hline Rejeito & Contaminação do solo & 3 & 1 & 1 & 4 & 1 & 1 & 8 & BAIXO \\
\hline
\end{tabular}

FIGURA 8 - Exemplo de Planilha de Avaliação de Impactos Ambientais na Sede

Grau de Significância

Baixo (B) - menor ou igual a 10

Médio (M) - menor ou igual a 20

Alto $(A)$ - $\quad$ maior que 20 
A seguir são apresentadas as FIG. 9 a 20 referentes às avaliações dos impactos relacionados da USEXA.

\begin{tabular}{|c|c|c|c|c|c|c|c|c|c|}
\hline \multicolumn{10}{|c|}{ AVALIAÇÃO DE IMPACTOS - USEXA } \\
\hline \multicolumn{2}{|c|}{ C10.11 Purificação de nitrato de uranilo } & \multicolumn{2}{|c|}{ Data: } & & \multicolumn{2}{|c|}{ Folha: } & \multicolumn{2}{|c|}{ Elaborado por: } & \\
\hline & & \multicolumn{3}{|c|}{ Avaliação } & & \multicolumn{2}{|c|}{\begin{tabular}{c|} 
Filtro de \\
Significância
\end{tabular}} & \multirow[t]{2}{*}{\begin{tabular}{|c|} 
Resultado \\
da \\
Avaliação \\
\end{tabular}} & \multirow[t]{2}{*}{ Grau de Significância } \\
\hline Aspecto & Impacto & 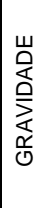 & 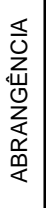 & 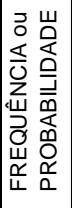 & 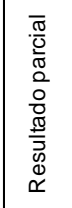 & 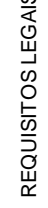 & 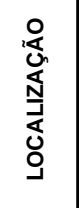 & & \\
\hline Vazamento - ácido nítrico & Contaminação da água & 3 & 3 & 1 & 6 & 1 & 3 & 24 & ALTO \\
\hline Urânio & Radiação ionizante & 3 & 2 & 1 & 5 & 1 & 3 & 20 & MÉDIO \\
\hline Efluentes industriais & Contaminação do solo & 2 & 1 & 1 & 3 & 1 & 3 & 12 & MÉDIO \\
\hline & Contaminação da água & 2 & 1 & 1 & 3 & 1 & 3 & 12 & MÉDIO \\
\hline Filtro contaminado & Contaminação do solo & 1 & 1 & 1 & 2 & 1 & 3 & 8 & BAIXO \\
\hline $\begin{array}{l}\text { Vazamento de TBP, } \\
\text { querosene, etc. }\end{array}$ & $\begin{array}{l}\text { Contaminação do solo, água, } \\
\text { saúde trabalhador, incêndio, } \\
\text { explosões }\end{array}$ & 3 & 3 & 1 & 6 & 1 & 3 & 24 & ALTO \\
\hline Rejeito & Contaminação do solo & 3 & 1 & 1 & 4 & 1 & 3 & 16 & MÉDIO \\
\hline
\end{tabular}

FIGURA 9 - Planilha de Avaliação de Impactos Ambientais da C10.11

AVALIAÇÃO DE IMPACTOS - USEXA

C10 12 - PRODUÇÃO DE TRIÓXIDO DE URÂNIO $\left(\mathrm{UO}_{3}\right)$ Data: Folha: Elaborado por:

\begin{tabular}{|c|c|c|c|c|c|c|c|c|c|}
\hline & & \multicolumn{3}{|c|}{ Avaliação } & \multirow[b]{2}{*}{ 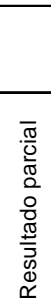 } & \multicolumn{2}{|c|}{$\begin{array}{c}\text { Filtro de } \\
\text { Significância }\end{array}$} & \multirow[t]{2}{*}{$\begin{array}{c}\text { Resultado } \\
\text { da } \\
\text { Avaliação }\end{array}$} & \multirow[t]{2}{*}{ Grau de Significância } \\
\hline Aspecto & Impacto & 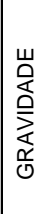 & 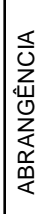 & 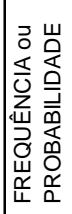 & & 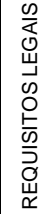 & 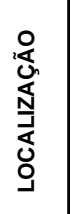 & & \\
\hline Vazamento - Amônia & Contaminação do ar & 3 & 3 & 1 & 6 & 1 & 3 & 24 & ALTO \\
\hline Urânio & Radiação ionizante & 3 & 2 & 1 & 5 & 1 & 3 & 20 & MÉDIO \\
\hline \multirow[t]{2}{*}{ Efluentes industriais } & Contaminação do solo & 2 & 1 & 1 & 3 & 1 & 3 & 12 & MÉDIO \\
\hline & Contaminação da água & 2 & 1 & 1 & 3 & 1 & 3 & 12 & MÉDIO \\
\hline Filtro contaminado & Contaminação do solo & 1 & 1 & 1 & 2 & 1 & 3 & 8 & BAIXO \\
\hline Rejeito & Contaminação do solo & 3 & 1 & 1 & 4 & 1 & 3 & 16 & MÉDIO \\
\hline
\end{tabular}

FIGURA 10 - Planilha de Avaliação de Impactos Ambientais da C10.12 
AVALIAÇÃO DE IMPACTOS - USEXA

\begin{tabular}{|c|c|c|c|c|c|c|c|c|c|}
\hline \multicolumn{2}{|c|}{ C10 13 - PRODUÇÃO DE TETRAFLUORETO DE URÂNIO (UF 4 ) } & \multicolumn{2}{|c|}{ Data: } & & \multicolumn{2}{|c|}{ Folha: } & \multicolumn{2}{|c|}{ Elaborado por: } & \multirow{3}{*}{ Grau de Significância } \\
\hline & & \multicolumn{3}{|c|}{ Avaliação } & & \multicolumn{2}{|c|}{$\begin{array}{c}\text { Filtro de } \\
\text { Significância }\end{array}$} & $\begin{array}{c}\text { Resultado } \\
\text { da } \\
\text { Avaliação }\end{array}$ & \\
\hline Aspecto & Impacto & 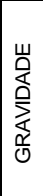 & 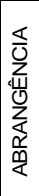 & 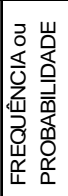 & 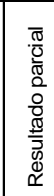 & 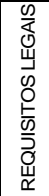 & 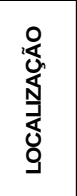 & & \\
\hline Vazamento - Amônia & Contaminação da água & 3 & 3 & 1 & 6 & 1 & 3 & 24 & ALTO \\
\hline \multirow[t]{2}{*}{ Vazamento - HF } & Saúde dos trabalhadores & 3 & 3 & 1 & 6 & 1 & 3 & 24 & ALTO \\
\hline & Danos a instalação & 3 & 2 & 1 & 5 & 1 & 3 & 20 & MÉDIO \\
\hline \multirow[t]{2}{*}{ Efluentes industriais } & Contaminação do solo & 2 & 1 & 1 & 3 & 1 & 3 & 12 & MÉDIO \\
\hline & Contaminação da água & 2 & 1 & 1 & 3 & 1 & 3 & 12 & MÉDIO \\
\hline Vazamento de $\mathrm{UO}_{3}$ & Radiação ionizante & 3 & 1 & 1 & 4 & 1 & 3 & 16 & MÉDIO \\
\hline
\end{tabular}

FIGURA 11 - Planilha de Avaliação de Impactos Ambientais da C10.13

AVALIAÇÃO DE IMPACTOS - USEXA

C10.15 - ESTOCAGEM DE MATÉRIA PRIMA

Data: Folha: Elaborado por:

\begin{tabular}{|c|c|c|c|c|c|c|c|c|c|}
\hline & & \multicolumn{3}{|c|}{ Avaliação } & \multirow[b]{2}{*}{ 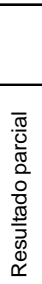 } & \multicolumn{2}{|c|}{$\begin{array}{c}\text { Filtro de } \\
\text { Significância }\end{array}$} & \multirow[t]{2}{*}{$\begin{array}{c}\text { Resultado } \\
\text { da } \\
\text { Avaliação } \\
\end{array}$} & \multirow[t]{2}{*}{ Grau de Significância } \\
\hline Aspecto & Impacto & 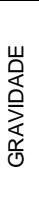 & 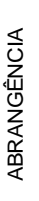 & 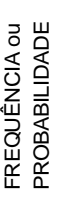 & & 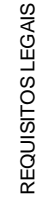 & 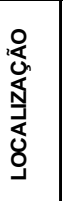 & & \\
\hline Matéria-prima & Radiação ionizante & 3 & 2 & 1 & 5 & 1 & 3 & 20 & MÉDIO \\
\hline \multirow[t]{2}{*}{ Efluentes industriais } & Contaminação do solo & 2 & 1 & 1 & 3 & 1 & 3 & 12 & MÉDIO \\
\hline & Contaminação da água & 2 & 1 & 1 & 3 & 1 & 3 & 12 & MÉDIO \\
\hline Filtro contaminado & Contaminação do solo & 1 & 1 & 1 & 2 & 1 & 3 & 8 & BAIXO \\
\hline
\end{tabular}

FIGURA 12 - Planilha de Avaliação de Impactos Ambientais da C10.15

AVALIAÇÃO DE IMPACTOS - USEXA

\begin{tabular}{|c|c|c|c|c|c|c|c|c|c|}
\hline \multirow{2}{*}{\multicolumn{2}{|c|}{$\begin{array}{l}\text { C10.21 - PRODUÇÃO DE HEXAFLUORETO DE URÂNIO }\left(\text { UF }_{6}\right) \\
\text { C10.23 - DESTILAÇÃO DE HEXAFLUORETO DE URÂNIO }\left(\mathrm{UF}_{6}\right)\end{array}$}} & \multicolumn{2}{|c|}{ Data: } & & \multicolumn{2}{|c|}{ Folha: } & \multicolumn{2}{|c|}{ Elaborado por: } & \multirow{4}{*}{ Grau de Significância } \\
\hline & & & & & \multirow{2}{*}{\multicolumn{3}{|c|}{$\begin{array}{c}\text { Filtro de } \\
\text { Significância }\end{array}$}} & \multirow{3}{*}{$\begin{array}{l}\text { Resultado } \\
\text { da } \\
\text { Avaliação }\end{array}$} & \\
\hline \multirow[b]{2}{*}{ Aspecto } & & \multicolumn{3}{|c|}{ Avaliação } & & & & & \\
\hline & Impacto & 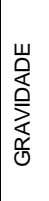 & 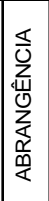 & 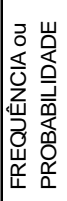 & 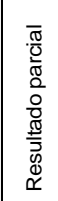 & 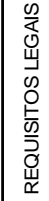 & 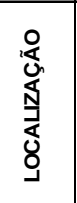 & & \\
\hline \multirow[t]{2}{*}{ Vazamento de $\mathrm{UF}_{4}$} & Danos à saude dos trabalhadores & 3 & 1 & 1 & 4 & 1 & 3 & 16 & MÉDIO \\
\hline & Radiação ionizante & 3 & 1 & 1 & 4 & 1 & 3 & 16 & MÉDIO \\
\hline Vazamento de flúor & Danos à saude dos trabalhadores & 3 & 3 & 1 & 6 & 1 & 3 & 24 & ALTO \\
\hline \multirow[t]{2}{*}{\begin{tabular}{|l|} 
Efluentes industriais \\
\end{tabular}} & Contaminação do solo & 2 & 1 & 1 & 3 & 1 & 3 & 12 & MÉDIO \\
\hline & Contaminação da água & 2 & 1 & 1 & 3 & 1 & 3 & 12 & MÉDIO \\
\hline Vazamento de $\mathrm{UF}_{6}$ & Danos à saude dos trabalhadores & 3 & 3 & 1 & 6 & 1 & 3 & 24 & ALTO \\
\hline Rejeito & Contaminação do solo & 3 & 1 & 1 & 4 & 1 & 3 & 16 & MÉDIO \\
\hline
\end{tabular}

FIGURA 13 - Planilha de Avaliação de Impactos Ambientais da C10.21 e C10.23 
AVALIAÇÃO DE IMPACTOS - USEXA

\begin{tabular}{|c|c|c|c|c|c|c|c|c|c|}
\hline \multicolumn{2}{|c|}{ C10.22 - PRODUÇÃO DE FLÚOR } & \multicolumn{2}{|c|}{ Data: } & & \multicolumn{2}{|c|}{ Folha: } & \multicolumn{2}{|c|}{ Elaborado por: } & \multirow{3}{*}{ Grau de Significância } \\
\hline & & \multicolumn{3}{|c|}{ Avaliação } & \multirow[b]{2}{*}{ 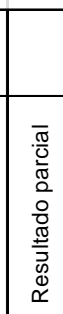 } & \multicolumn{2}{|c|}{\begin{tabular}{|c|} 
Filtro de \\
Significância
\end{tabular}} & \multirow[t]{2}{*}{$\begin{array}{c}\text { Resultado } \\
\text { da } \\
\text { Avaliação }\end{array}$} & \\
\hline Aspecto & Impacto & 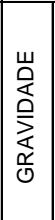 & 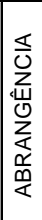 & 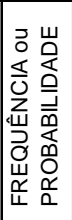 & & 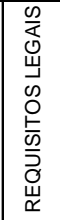 & 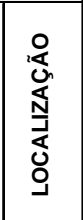 & & \\
\hline Vazamento de HF & Danos à saude dos trabalhadores & 3 & 3 & 1 & 6 & 1 & 3 & 24 & ALTO \\
\hline Vazamento de flúor & Danos à saude dos trabalhadores & 3 & 3 & 1 & 6 & 1 & 3 & 24 & ALTO \\
\hline \multirow[t]{2}{*}{ Efluentes industriais } & Contaminacão do solo & 2 & 1 & 1 & 3 & 1 & 3 & 12 & MÉDIO \\
\hline & Contaminação da água & 2 & 1 & 1 & 3 & 1 & 3 & 12 & MÉDIO \\
\hline Efluentes gasosos & Contaminação do ar & 1 & 2 & 1 & 3 & 1 & 3 & 12 & MÉDIO \\
\hline
\end{tabular}

FIGURA 14 - Planilha de Avaliação de Impactos Ambientais da C10.22

AVALIAÇÃO DE IMPACTOS - USEXA

\begin{tabular}{|c|c|c|c|c|c|c|c|c|c|}
\hline \multicolumn{4}{|c|}{ C10.31- RECUPERAÇÃO DE URÂNIO E TRATAMENTO DE REJEITOS } & & \multicolumn{2}{|c|}{ Folha: } & & \multicolumn{2}{|c|}{ Elaborado por: } \\
\hline & & \multicolumn{3}{|c|}{ Avaliação } & \multicolumn{3}{|c|}{$\begin{array}{c}\text { Filtro de } \\
\text { Significância }\end{array}$} & \multirow[t]{2}{*}{\begin{tabular}{|c|} 
Resultado \\
da \\
Avaliação \\
\end{tabular}} & \multirow[t]{2}{*}{ Grau de Significância } \\
\hline Aspecto & Impacto & 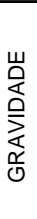 & 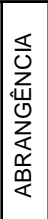 & 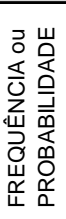 & 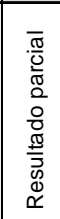 & 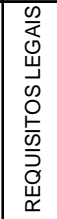 & 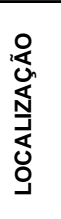 & & \\
\hline \multirow[t]{3}{*}{ Efluentes industriais } & Danos à saude dos trabalhadores & 2 & 1 & 1 & 3 & 1 & 3 & 12 & MÉDIO \\
\hline & Radiação ionizante & 2 & 1 & 1 & 3 & 1 & 3 & 12 & MÉDIO \\
\hline & Alteração do solo e água & 3 & 3 & 1 & 6 & 1 & 3 & 24 & ALTO \\
\hline Rejeitos & Alteração na qualidade do solo & 3 & 1 & 1 & 4 & 1 & 3 & 16 & MÉDIO \\
\hline
\end{tabular}

FIGURA 15 - Planilha de Avaliação de Impactos Ambientais da C10.31 AVALIAÇÃO DE IMPACTOS - USEXA

\begin{tabular}{|c|c|c|c|c|c|c|c|c|c|}
\hline \multicolumn{2}{|c|}{ C10.32 - ARMAZENAMENTO INICIAL DE REJEITOS DA USEXA } & & & & \multicolumn{2}{|c|}{ Folha: } & & \multicolumn{2}{|c|}{ Elaborado por: } \\
\hline & & \multicolumn{3}{|c|}{ Avaliação } & & \multicolumn{2}{|c|}{$\begin{array}{c}\text { Filtro de } \\
\text { Significância }\end{array}$} & $\begin{array}{l}\text { Resultado } \\
\text { da } \\
\text { Avaliação }\end{array}$ & Grau de Significância \\
\hline Aspecto & Impacto & 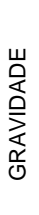 & 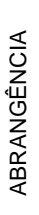 & 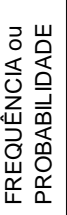 & 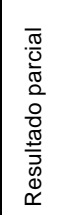 & 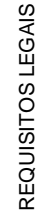 & 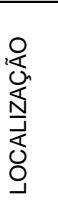 & & \\
\hline \multirow[t]{2}{*}{ Tambores com rejeito } & Danos à saude dos trabalhadores & 2 & 1 & 1 & 3 & 1 & 3 & 12 & MÉDIO \\
\hline & Radiação ionizante & 3 & 1 & 1 & 4 & 1 & 3 & 16 & MÉDIO \\
\hline Particulados de cimento & Contaminação do solo e água & 1 & 1 & 1 & 2 & 1 & 3 & 8 & BAIXO \\
\hline
\end{tabular}


AVALIAÇÃO DE IMPACTOS - USEXA

\begin{tabular}{|c|c|c|c|c|c|c|c|c|c|}
\hline C10.41 - UTILIDADES & & Dat & & & Folh & & & Elaborado & \\
\hline & & & valia & ção & & $\begin{array}{r}F \\
\text { Sigr }\end{array}$ & $\begin{array}{l}\text { de } \\
\text { sância }\end{array}$ & $\begin{array}{c}\text { Resultado } \\
\text { da } \\
\text { Avaliação }\end{array}$ & Grau de Significância \\
\hline Aspecto & Impacto & 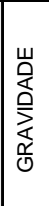 & 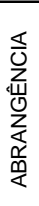 & 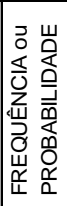 & 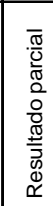 & 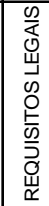 & 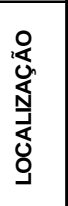 & & \\
\hline Gases do gerador & Contaminação do ar & 1 & 1 & 1 & 2 & 1 & 3 & 8 & BAIXO \\
\hline Vazamento de óleo diesel & Contaminação do solo e água & 2 & 2 & 1 & 4 & 1 & 3 & 16 & MÉDIO \\
\hline
\end{tabular}

FIGURA 17 - Planilha de Avaliação de Impactos Ambientais da C10.41

AVALIAÇÃO DE IMPACTOS - USEXA

\begin{tabular}{|c|c|c|c|c|c|c|c|c|c|}
\hline \multicolumn{2}{|c|}{ C10.42 - ESTOCAGEM DE PRODUTOS QUÍMICOS } & \multicolumn{2}{|c|}{ Data: } & & \multicolumn{2}{|c|}{ Folha: } & & \multicolumn{2}{|c|}{ Elaborado por: } \\
\hline & & \multicolumn{3}{|c|}{ Avaliação } & \multirow[b]{2}{*}{$\begin{array}{l}\bar{\pi} \\
\frac{\pi}{0} \\
\frac{\pi}{\pi} \\
\frac{0}{0} \\
0 \\
\frac{0}{\pi} \\
\frac{\pi}{5} \\
0 \\
\mathbb{0}\end{array}$} & \multicolumn{2}{|c|}{\begin{tabular}{|c|} 
Filtro de \\
Significância
\end{tabular}} & \multirow[t]{2}{*}{$\begin{array}{c}\text { Resultado } \\
\text { da } \\
\text { Avaliação }\end{array}$} & \multirow[t]{2}{*}{ Grau de Significância } \\
\hline Aspecto & Impacto & 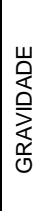 & 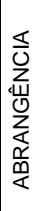 & 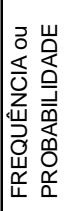 & & 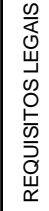 & 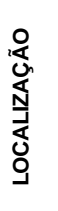 & & \\
\hline \multirow{2}{*}{$\begin{array}{l}\text { Vazamento de produtos } \\
\text { químicos }\end{array}$} & Contaminação do solo e água & 3 & 2 & 1 & 5 & 1 & 3 & 20 & MÉDIO \\
\hline & Danos à saúde dos trabalhadores & 2 & 2 & 1 & 4 & 1 & 3 & 16 & MÉDIO \\
\hline Explosões & $\begin{array}{l}\text { Danos à saude dos trabalhadores } \\
\text { e instalações }\end{array}$ & 3 & 1 & 1 & 4 & 1 & 3 & 16 & MÉDIO \\
\hline Incêndios & $\begin{array}{l}\text { Danos à saúde dos trabalhadores } \\
\text { e instalações }\end{array}$ & 3 & 2 & 1 & 5 & 1 & 3 & 20 & MÉDIO \\
\hline Corrosão & $\begin{array}{l}\text { Danos à saúde dos trabalhadores } \\
\text { e instalações }\end{array}$ & 2 & 1 & 1 & 3 & 1 & 3 & 12 & MÉDIO \\
\hline Vazamento de HF & Danos à saude dos trabalhadores & 3 & 3 & 1 & 6 & 1 & 3 & 24 & ALTO \\
\hline
\end{tabular}

FIGURA 18 - Planilha de Avaliação de Impactos Ambientais da C10.42

AVALIAÇÃO DE IMPACTOS - USEXA

\begin{tabular}{|c|c|c|c|c|c|c|c|c|c|}
\hline \multirow[t]{2}{*}{ C10.43 - SUBESTAÇÃO } & & \multicolumn{2}{|c|}{ Data: } & & \multicolumn{2}{|c|}{ Folha: } & & \multicolumn{2}{|c|}{ Elaborado por: } \\
\hline & & \multicolumn{3}{|c|}{ Avaliação } & & \multicolumn{2}{|c|}{$\begin{array}{c}\text { Filtro de } \\
\text { Significância }\end{array}$} & $\begin{array}{c}\text { Resultado } \\
\text { da } \\
\text { Avaliação }\end{array}$ & Grau de Significância \\
\hline Aspecto & Impacto & 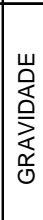 & 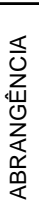 & 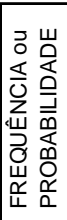 & $\begin{array}{l}\frac{\overline{0}}{0} \\
\frac{0}{\pi} \\
\frac{0}{0} \\
\frac{0}{0} \\
\frac{\pi}{5} \\
\frac{0}{0} \\
0 \\
\square\end{array}$ & 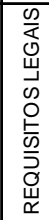 & 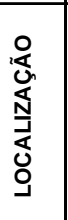 & & \\
\hline Gases do gerador & Contaminação do ar & 1 & 1 & 1 & 2 & 1 & 3 & 8 & BAIXO \\
\hline Vazamento de óleo diesel & Contaminação do solo e água & 2 & 2 & 1 & 4 & 1 & 3 & 16 & MÉDIO \\
\hline
\end{tabular}

FIGURA 19 - Planilha de Avaliação de Impactos Ambientais da C10.43 
A avaliação dos impactos ambientais comuns das unidades foi realizada em uma única planilha (Figura 20).

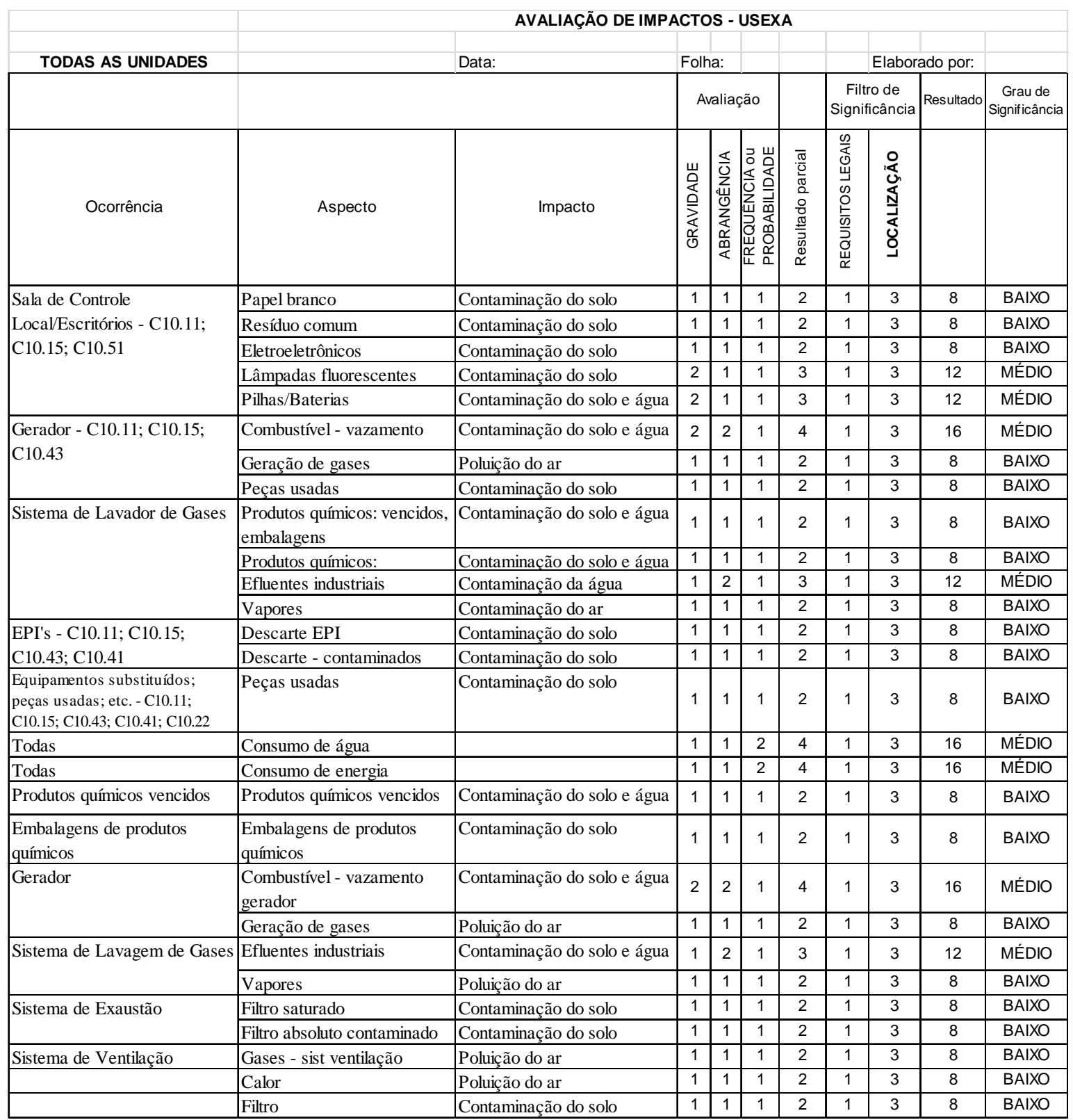

FIGURA 20 - Planilha de Avaliação de Impactos Ambientais comuns nas

unidades

\subsubsection{Objetivos, metas e programas}

A definição dos objetivos e metas foi gerada a partir da análise dos principais impactos estabelecidos nas Planilhas de Avaliação dos Impactos Ambientais e dos principais perigos definidos por MARIN (2005) sobre Análise de Riscos e Avaliação de Impacto Ambiental, em uma Unidade de Produção de Hexafluoreto de Urânio. 
Os objetivos são definidos para atender à política ambiental, refletindo os propósitos para o desempenho ambiental. Posteriormente, as metas ambientais foram estabelecidas para atingir estes objetivos dentro de prazos específicos (sugestão), sendo recomendável que tais objetivos e metas sejam analisadas e revisadas anualmente.

O estabelecimento de objetivos e metas é dinâmico e deve ser implementada conforme a revisão de processos e legislações mais restritivas.

Na TAB. 15 são apresentos os principais objetivos, metas e os programas específicos sugeridos para a USEXA e os documentos de referência existentes.

\subsubsection{Plano de ação}

Os objetivos e metas podem ser reunidos em um Plano de Gestão Ambiental - PGA ou Plano de Ação - PA. Este documento permite reunir informações como: prazos, recursos, responsabilidades em um único documento, para melhor acompanhamento das atividades e conclusão das metas propostas. Á medida que as metas forem alcançadas, novas metas são estabelecidas e o PGA atualizado. É recomendável que a atualização seja realizada anualmente, juntamente com a atribuição de recursos. A função principal do PGA é o planejamento e deve ser preenchida por aqueles que elaboraram as planilhas de aspectos e impactos.

A USEXA compilará os impactos ambientais em um PGA reunindo as informações quanto à descrição da ação a empreender, as etapas que serão seguidas para atingir a meta proposta, a legislação aplicável, o orçamento destinado e de que forma ele vai ser aplicado até a meta ser concluída e a atribuição de responsabilidades. Na FIG.21 é apresentada um modelo de PGA que poderá ser utilizado pela USEXA. 
TABELA 15 - Objetivos, Metas e Programas propostos para a USEXA

\begin{tabular}{|c|c|c|c|}
\hline Objetivos & Origem & Metas & Documentos de referência / Programas sugeridos \\
\hline $\begin{array}{l}\text { 1. Prevenir } \\
\text { incêndios }\end{array}$ & $\begin{array}{l}\text { Planilha e } \\
\text { MARIN, } \\
2005\end{array}$ & $\begin{array}{l}\text { 1. Treinar os operadores em combate a incêndio, até } 201 X ; 2 \text {. } \\
\text { Treinar os funcionários administrativos em combate a } \\
\text { incêndio, até } 201 X ; 3 \text {. Implantar Programa de Prevenção a } \\
\text { Incêndios, até } 201 X\end{array}$ & $\begin{array}{l}\text { Combate a Incêndios na USEXA - Instrução } \\
\text { Detalhada } n^{\circ} \text { : } \\
\text { ID C1099-PRE-01.001 (CTMSP, 2011b). } \\
\text { - Programa de Manutenção }\end{array}$ \\
\hline $\begin{array}{l}\text { 2. Prevenir } \\
\text { explosões }\end{array}$ & $\begin{array}{l}\text { Planilha e } \\
\text { MARIN, } \\
2005 \\
\end{array}$ & $\begin{array}{l}\text { 1. Elaborar Programa de Prevenção e Emergência a } \\
\text { Explosões até } 201 X ; 2 \text {. Implantar o Programa até 201X; } 3 . \\
\text { Treinar os operadores em casos de explosões, até 201X }\end{array}$ & - Programa de Manutenção \\
\hline $\begin{array}{l}\text { 3. Reduzir } \\
\text { riscos de } \\
\text { vazamento } \\
\text { de } \\
\text { substâncias } \\
\text { químicas }\end{array}$ & $\begin{array}{l}\text { Planilha } \\
\text { MARIN, } \\
2005\end{array}$ & $\begin{array}{l}\text { 1. Treinar técnicos para inspeções periódicas, até } 201 X ; 2 \text {. } \\
\text { Adquirir mantas absorvedoras, para cada unidade, até } 201 X ; \\
\text { 3. Treinar os funcionários em casos de vazamentos de } \\
\text { substâncias químicas; } 4 \text {. Elaborar o Plano de Emergência } \\
\text { Ambiental não radioativa }\end{array}$ & $\begin{array}{l}\text { - Combate a vazamentos de gases perigosos na } \\
\text { USEXA - Instrução Detalhada } n^{\circ} \text { ID-C1099-PRE- } \\
01.002 \text { (CTMSP, 2011c) } \\
\text { - Programa de Manutenção }\end{array}$ \\
\hline $\begin{array}{l}\text { 4. Treinar os } \\
\text { funcionários } \\
\text { em caso de } \\
\text { emergência } \\
\text { com HF }\end{array}$ & $\begin{array}{l}\text { Avaliação } \\
\text { de impactos }\end{array}$ & $\begin{array}{l}\text { 1. Treinar os operadores em casos de vazamentos, até } 201 X ; \\
\text { 2. Implantar programa de prevenção a vazamentos, até } 201 X\end{array}$ & $\begin{array}{l}\text { - Combate a vazamentos de gases perigosos na } \\
\text { USEXA - Instrução Detalhada } \mathrm{n}^{\circ} \text { ID-C1099-PRE- } \\
01.002 \text { (CTMSP, 2011c) } \\
\text { - Combate a vazamentos de líquidos contendo } \\
\text { materiais radioativos e/ou perigosos na USEXA - } \\
\text { Instrução Detalhada n ID-C1099-PRE-01.003 } \\
\text { (CTMSP, 2011d) (Procedimento de Conscientização e } \\
\text { Treinamento) } \\
\text { - Programa de Treinamento }\end{array}$ \\
\hline $\begin{array}{ll}\text { 5. Reduzir a } \\
\text { emissão de } \\
\text { efluentes } \\
\text { líquidos } \\
\text { gasosos }\end{array}$ & $\begin{array}{l}\text { Avaliação } \\
\text { de impactos }\end{array}$ & $\begin{array}{l}\text { 1. Caracterizar e quantificar todas as emissões líquidas até } \\
201 X ; 2 \text {. Caracterizar e quantificar todas as emissões } \\
\text { gasosas até 201X; 3. Estudar processos alternativos de } \\
\text { tratamento de efluentes líquidos até 201X; 4. Estudar } \\
\text { processos alternativos de tratamento de efluentes gasosos } \\
\text { até } 201 X \text { e substituição do diesel por biodiesel; 5. Elaboração } \\
\text { do PEI - Plano de Emergência Individual; } 6 \text {. Operação do } \\
\text { SITEA até } 201 X\end{array}$ & $\begin{array}{l}\text { - Combate a vazamentos de líquidos contendo } \\
\text { materiais radioativos e/ou perigosos na USEXA - } \\
\text { Instrução Detalhada nº ID-C1099-PRE-01.003 } \\
\text { (CTMSP, 2011d). } \\
\text { - Combate a vazamentos de gases perigosos na } \\
\text { USEXA - Instrução Detalhada } n^{\circ} \text { ID-C1099-PRE- } \\
\text { 01.002 (CTMSP, 2011c). } \\
\text { - Programa de redução de efluentes líquidos e } \\
\text { gasosos }\end{array}$ \\
\hline
\end{tabular}




\begin{tabular}{|c|c|c|c|}
\hline Objetivos & Origem & Metas & Documentos de referência / Programa sugeridos \\
\hline $\begin{array}{l}\text { 6. Reduzir o } \\
\text { consumo de } \\
\text { água } \quad \text { e } \\
\text { energia } \\
\text { elétrica }\end{array}$ & $\begin{array}{l}\text { Avaliação } \\
\text { de impactos }\end{array}$ & $\begin{array}{l}\text { 1. Quantificar o consumo de água e energia elétrica dos } \\
\text { setores administrativos e industriais até } 201 X ; 2 \text {. Promover } \\
\text { conscientização sobre economia de água e energia, até } \\
201 X ; 3 \text {. Estudar os processos industriais para reuso da água } \\
\text { até } 201 X\end{array}$ & - Programa de uso racional da água e energia elétrica \\
\hline $\begin{array}{l}7 . \quad \text { Implantar } \\
\text { coleta } \\
\text { seletiva e } \\
\text { gerenciamen } \\
\text { to de } \\
\text { resíduos } \\
\text { sólidos }\end{array}$ & $\begin{array}{l}\text { Avaliação } \\
\text { de impactos }\end{array}$ & $\begin{array}{l}\text { 1. Caracterizar e quantificar os resíduos sólidos e os } \\
\text { recicláveis, até } 201 X ; 2 \text {. Treinar os funcionários para a coleta } \\
\text { seletiva até } 201 X \\
\text { 3. Elaborar Programa de Coleta Seletiva que inclui os } \\
\text { resíduos perigosos, inclusive as embalagens de produtos } \\
\text { químicos até } 201 X\end{array}$ & $\begin{array}{l}\text { - Coleta Seletiva de Resíduos Recicláveis - Instrução } \\
\text { Detalhada n ID-CTMSP-SGA-01.001 (CTMSP, 2007) } \\
\text { - Ordem Interna n 70-07/Coleta Seletiva de Resíduos } \\
\text { Recicláveis(CTMSP, 2007a). } \\
\text { - Programa de Resíduos Sólidos }\end{array}$ \\
\hline $\begin{array}{l}\text { 8. Qualificar } \\
\text { e treinar os } \\
\text { funcionários } \\
\text { em } \\
\text { desenvolvim } \\
\text { ento pessoal } \\
\text { e educação } \\
\text { ambiental }\end{array}$ & $\begin{array}{l}\text { Avaliação } \\
\text { de impactos }\end{array}$ & $\begin{array}{l}\text { 1. Elaborar um Programa de Treinamento e Conscientização } \\
\text { com diretrizes modernas de gestão pessoal, educação e } \\
\text { psicologia ambiental }\end{array}$ & $\begin{array}{l}\text { (Procedimento de Conscientização e Treinamento) } \\
\text { - Programa de Treinamento }\end{array}$ \\
\hline
\end{tabular}


CENTRO TECNOLÓGICO DA MARINHA EM SÃO PAULO PLANO DE GESTÃO AMBIENTAL

Nº DA AÇÃo

PRIORIDADE

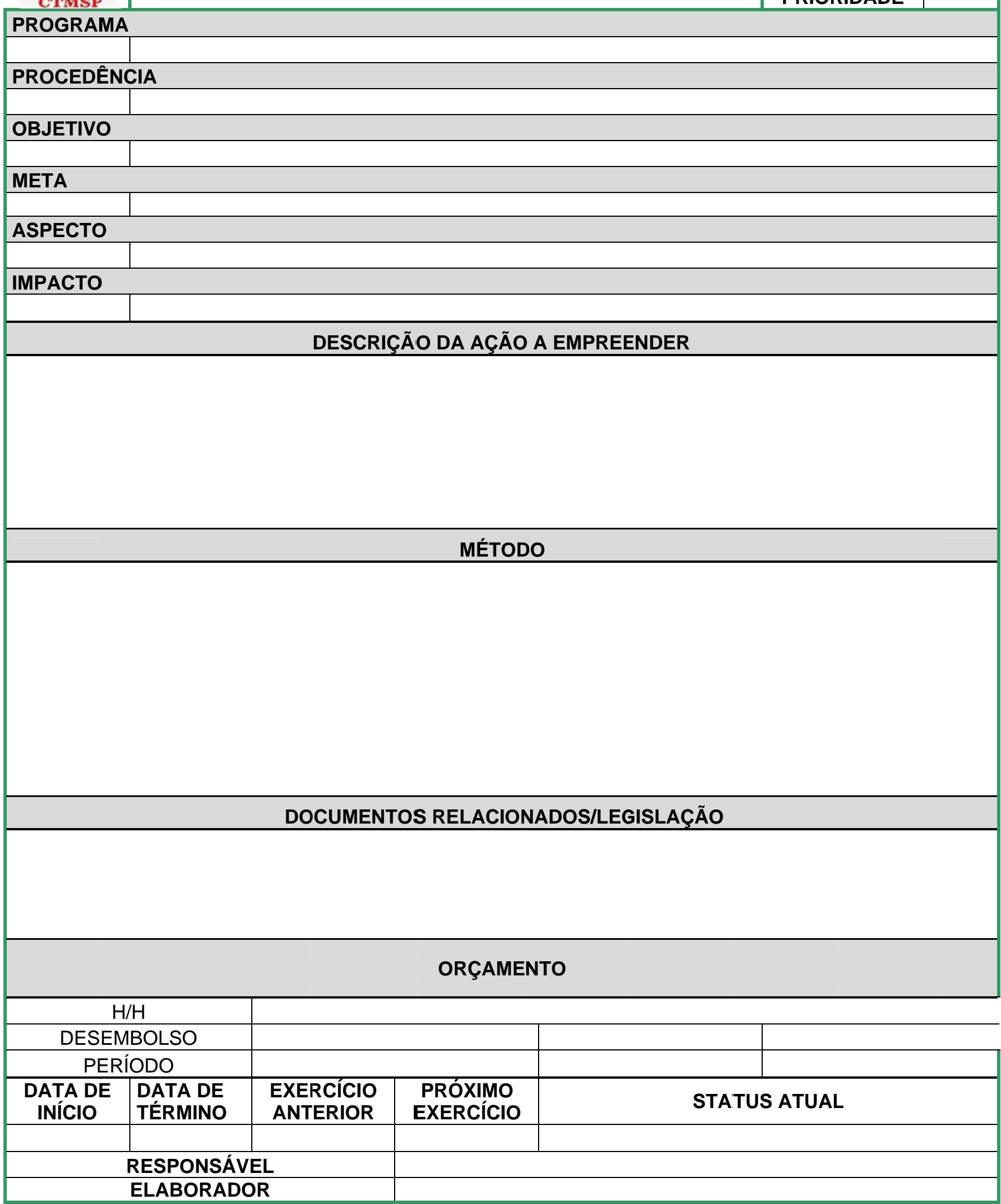

FIGURA 21 - Modelo de PGA proposto para a USEXA 


\subsubsection{Programas específicos}

A partir dos objetivos e metas propostas, foram sugeridos programas específicos, listados a seguir:

- Programa de Manutenção;

- Programa de Treinamento;

- Programa de Redução de Efluentes Líquidos e Gasosos;

- Programa de Uso Racional da Água e Energia Elétrica; e

- Programa de Resíduos Sólidos.

A elaboração de programas específicos contribui de forma significativa para que as metas e objetivos sejam alcançados.

A estruturação dos dois primeiros programas sugeridos (manutenção) contribuirá sobremaneira para que os objetivos mais importantes sejam alcançados.

\subsection{Implementação e Operação}

\subsubsection{Funções, responsabilidades e autoridades}

Na FIG. 22 é apresentado o organograma do CTMSP, destacando-se as unidades mencionadas no SGA.

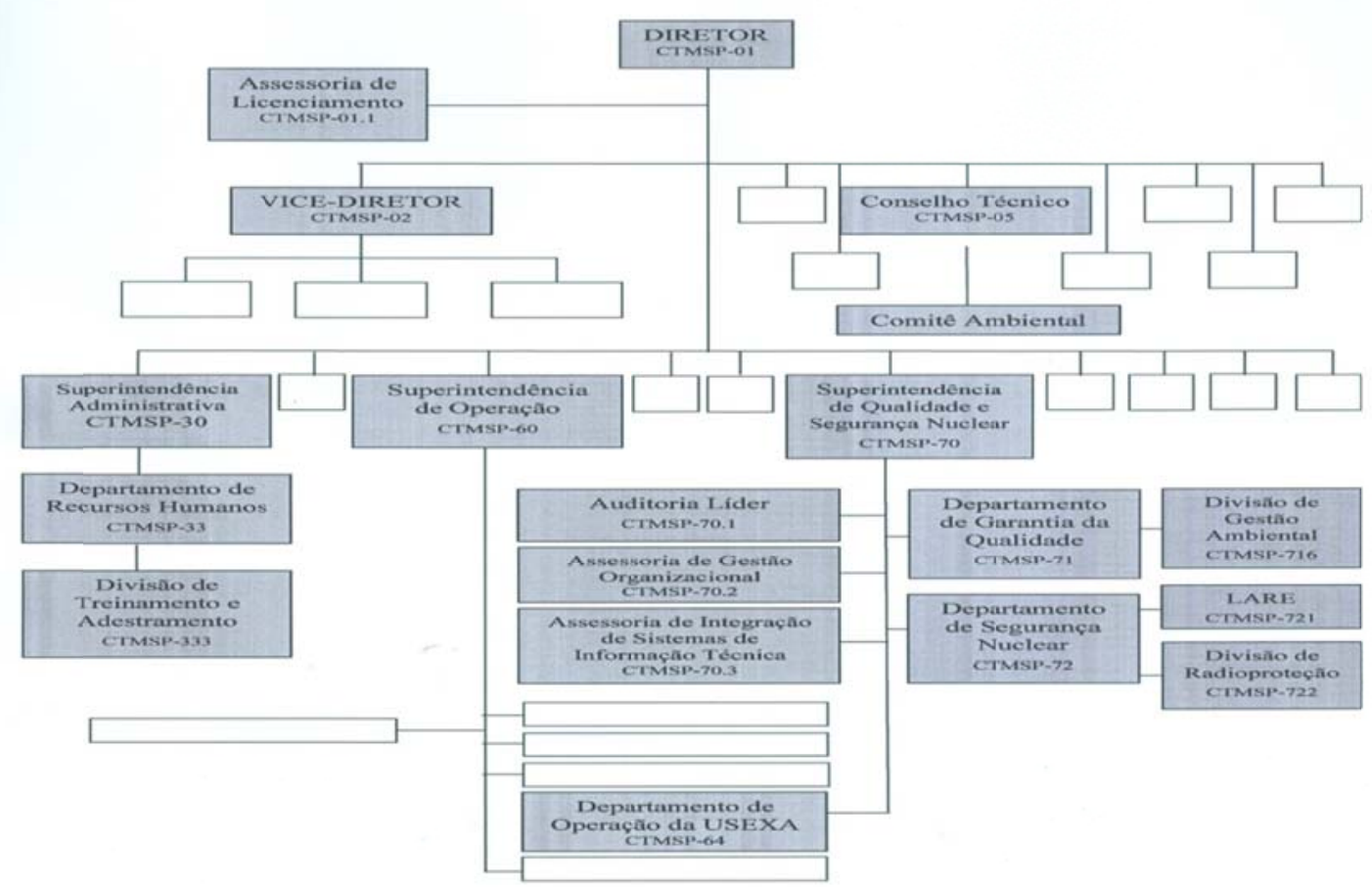

FIGURA 22 - Organograma do CTMSP, com os destaques para áreas envolvidas neste trabalho 
A organização e atividades do CTMSP estão estruturadas no Regulamento aprovado pela Portaria N²14/DGMM de 19 de agosto de 2008. No Capítulo III (Da Organização), o Artigo $5^{\circ}$ traz que: "O CTMSP é subordinado militar e administrativamente à Diretoria-Geral do Material da Marinha". A USEXA está subordinada à Superintendência de Operação (Departamento de Operação da USEXA) do CTMSP, que responde diretamente ao Sr. Diretor, conforme FIG. 22 abaixo.

\subsubsection{Competência, treinamento e conscientização}

Para implantação do SGA, e cumprimento do item 4.4.2 da Norma ABNT NBR ISO 14001(ABNT, 2004) a mesma apresenta as seguintes diretrizes:

- a organização deve assegurar que qualquer pessoa que, para ela ou em seu nome, realize tarefas que tenham o potencial de causar impacto(s) ambiental(is) significativo(s) identificados pela organização, seja competente com base em formação apropriada, treinamento ou experiência, devendo reter os registros associados;

- a organização deve identificar as necessidades de treinamento associadas com seus aspectos ambientais e seu sistema da gestão ambiental. Ela deve prover treinamento ou tomar alguma ação para atender a essas necessidades, devendo manter os registros associados; e

- a organização deve estabelecer, implementar e manter procedimento(s) para fazer que as pessoas que trabalhem para ela ou em seu nome estejam conscientes da importância de se estar em conformidade com a política ambiental e com os requisitos do sistema da gestão ambiental, dos aspectos ambientais significativos e respectivos impactos reais ou potenciais associados com seu trabalho e dos benefícios ambientais provenientes da melhoria do desempenho pessoal, de suas funções e responsabilidades em atingir a conformidade com os requisitos do sistema da gestão ambiental e das potenciais consequências da inobservância de procedimento(s) especificado(s).

A etapa de treinamento e conscientização da implantação do SGA deve abranger os funcionários, com atribuições na área ambiental ou não, para que estejam conscientes da importância do cumprimento da política e objetivos ambientais estabelecidos; das exigências legais e de outras definidas pela 
Unidade Organizacional - UO (grupo de pessoas e instalações com responsabilidades, autoridades e relações definidas, podendo ser uma Divisão, Departamento, Coordenadoria, Superintendência, ou parte ou combinação destes).

O Anexo A da ABNT NBR ISO 14001 (ABNT, 2004) traz a seguinte orientação: "conscientização, conhecimento, compreensão e competência podem ser obtidos ou melhorados por meio de treinamento, formação educacional ou experiência de trabalho".

O CTMSP dispõe do Procedimento PR-CTMSP-TRE-01 (CTMSP, 2001a) que "descreve a sistemática para identificação das necessidades, planejamento e execução de treinamento, como forma de capacitar os funcionários que executam atividades que influem na qualidade". Estes treinamentos são elaborados por cada área do CTMSP e sua aprovação envolve o Conselho Técnico e o Departamento de Recursos Humanos (Divisão de Treinamento e Adestramento).

A USEXA deverá elaborar documento semelhante, conforme Instrução Detalhada n ID-A2410-TRE.01.001_00 (CTMSP, 2011e) - Qualificação de Pessoal do Departamento da Garantia da Qualidade, de 2011. Neste documento são definidos os requisitos mínimos de escolaridade, experiência e proficiência para qualificação do pessoal responsável pela execução das atividades, assim como estabelece a forma de registro da competência desse pessoal para o exercício das atividades. Estes requisitos atendem aos requisitos específicos.

No final deste item, e para cumprir o objetivo apresentado neste trabalho, será apresentada uma proposta de documento/procedimento de Conscientização e Treinamentos para USEXA, melhorando a compreensão dos recursos humanos como elemento do SGA. Este item é considerado um dos mais importantes, pois é do recurso humano que depende não só o sucesso do SGA, como a segurança dos trabalhadores e da Usina.

O recurso humano é a mola precursora de todo e qualquer Sistema. Uma empresa pode ter recurso financeiro, matéria prima abundante, entretanto se não tiver o recurso humano motivado, seja por qualquer critério intrínseco que o motive, nenhum sistema terá sucesso. O Sistema é a roda e as engrenagens são a matéria prima, os recursos financeiros e os recursos humanos. Se uma das engrenagens estiver danificada, a roda não girará. 
Uma empresa pode planejar um sistema de gestão ambiental sem um recurso humano bem treinando e conscientizado, entretanto, não conseguirá resultados satisfatórios na implantação e operação se o recurso humano não estiver conscientizado e treinado. É nesta fase que se desenvolve o comprometimento dos funcionários com a gestão ambiental promovida pela organização.

Os métodos de treinamento costumam ser classificados como formais ou informais. Historicamente, o treinamento significava o treinamento formal, planejado com antecedência e com formato estruturado. Contudo, as evidências recentes indicam que as organizações têm usado cada vez mais o treinamento informal - não estruturado, não planejado e facilmente adaptável às situações e aos indivíduos - para ensinar habilidades e manter os funcionários atualizados.

A maneira pela qual as pessoas processam, internalizam e memorizam coisas novas não é necessariamente a mesma. Esse fato significa que o treinamento formal efetivo deve ser individualizado para refletir o estilo de aprendizado de cada funcionário (ROBBINS, 2002).

Além dos dois documentos citados acima, que darão subsídios para atender ao item da ABNT NBR ISO 14001 (ABNT, 2004) foi elaborado um documento com diretrizes para a estruturação dos treinamentos específicos na área de atuação profissional, dos treinamentos para operacionalização do SGA e os treinamentos em educação e psicologia ambiental e em gestão de pessoas (APÊNDICE B). Os três primeiros já são previstos em Sistemas de Gestão Ambiental, com exceção da introdução de conceitos de psicologia ambiental que estão sendo propostos. O último item, treinamentos em gestão de pessoas é o diferencial que este trabalho apresenta para Sistemas de Gestão.

Os treinamentos específicos na área de atuação profissional difundem os cuidados em todas as etapas e processos desenvolvidos, abordando questões como: segurança, minimização do desperdício de materiais e especialmente os voltados à manutenção, para atingir os objetivos e metas estabelecidos para USEXA. Estes cursos poderão ser ministrados por empresas especializadas ou por funcionários qualificados.

Já, os treinamentos para operacionalização do SGA são destinados aos funcionários com envolvimento profissional nas questões ambientais, agindo 
como principais motivadores na busca de uma melhoria contínua no desempenho ambiental. Estes treinamentos poderão ser ministrados por empresas especializadas ou por funcionários qualificados.

Os treinamentos em educação e psicologia ambiental foram propostos com base no trabalho de MATTIOLO et al (2009), intitulado "Diretrizes modernas de educação e psicologia ambiental na fase de conscientização e treinamento de Sistemas de Gestão Ambiental".

Estes treinamentos possibilitarão que o funcionário atue de forma consciente nas questões ambientais, não só na sua área de atuação profissional, e sim como um cidadão do mundo, onde quer que ele esteja.

Este item do SGA (treinamentos em educação ambiental) dará subsídios para o CTMSP atender à condicionante das licenças ambientais sobre educação ambiental, conforme Instrução Normativa $n^{\circ} 2$ (IBAMA, 2012), que estabelece as bases técnicas para programas de educação ambiental apresentado como medidas mitigadoras ou compensatórias, em cumprimento às condicionantes das licenças ambientais emitidas pelo IBAMA.

A seguir, são apresentados os principais conceitos e documentos que serviram de base para a elaboração dos treinamentos em educação e psicologia ambiental, para um desenvolvimento da visão global e ação local e a interiorização de conceitos de desenvolvimento sustentável:

\section{Educação e Psicologia Ambiental}

O SGA depende de educação ambiental para seu sucesso e que por sua vez precisa do estímulo que a implantação do sistema de gestão ambiental proporciona.

A educação ambiental possibilita a implementação de práticas para que se alcance o objetivo primordial da relação das pessoas, no caso os funcionários, com o ambiente que os cercam, fazendo com que suas ações permitam ações em prol do meio ambiente.

O envolvimento do ser humano é primordial, e com isso a gestão ambiental está vinculada à gestão do comportamento humano. A psicologia ambiental pode servir então, de aporte a algumas questões e contribuir significativamente com o desenvolvimento e a implantação do SGA (POL, 2003). 
A psicologia ambiental além do foco no comportamento pode ser útil na tomada de decisão, utilizando uma escala de valores adequados para determinada situação. A sustentabilidade, por exemplo, deve ser vista como um valor social positivo.

Apesar de existirem indícios do uso da psicologia ambiental há algum tempo, só veio à tona e foi utilizada em parceria com outras ciências, a partir da década de 1960, provavelmente a atual crise ambiental tenha solicitado o amparo da psicologia às outras áreas do conhecimento, pelo envolvimento do homem no processo de degradação ambiental (TASSARA, 2004). A psicologia ambiental atua na interface homem-meio ambiente.

$\mathrm{Na}$ implantação de um SGA uma série de aspectos psicológicos como valores, atitudes e condutas estão implícitas. Os psicólogos cognitivistas, empregando uma estratégia observacional, concentravam-se na relação entre a conduta ambientalmente responsável e algumas características psicológicas dos indivíduos, como suas atitudes, seus conhecimentos e sua personalidade (CORRAL-VERDUGO \& PINHEIRO, 1999).

\section{Programa Nacional de Educação Ambiental - ProNEA}

O ProNEA (Programa Nacional de Educação Ambiental) desempenha um importante papel na orientação de agentes públicos e privados para reflexão, a construção e a implementação de políticas públicas que possibilitem solucionar questões estruturais, almejando a sustentabilidade socioambiental. Este programa foi executado pela Coordenação de Educação Ambiental do Ministério da Educação e Cultura e pelos setores correspondentes do Ministério do Meio Ambiente/IBAMA, responsáveis pelas ações voltadas respectivamente ao sistema de ensino e à gestão ambiental.

O ProNEA previu três componentes: a) capacitação de gestores e educadores; b) desenvolvimento de ações educativas; e c) desenvolvimento de instrumentos e metodologias, contemplando sete linhas de ação:

- educação ambiental por meio do ensino formal;

- educação no processo de gestão ambiental;

- campanhas de educação ambiental para usuários de recursos naturais;

- cooperação com meios de comunicação e comunicadores sociais; 
- articulação e integração comunitária;

- articulação intra e interinstitucional; e

- rede de centros especializados em educação ambiental em todos os estados (PRONEA, 2005).

Um dos destaques do programa é o estímulo à inclusão da educação ambiental nos projetos públicos e privados que causem impactos ambientais, conforme a Lei n 6.938 (BRASIL, 1981), as Resoluções do CONAMA nº 001 (CONAMA, 1986) e $\mathrm{n}^{\circ} 237$ (CONAMA, 1997) e a citação no Compromisso de Goiânia realizado em 2004 (PRONEA, 2005), proposto ao CONAMA a regulamentação do componente de educação ambiental nos processos de licenciamento ambiental.

O Decreto $n^{0} 4.281$, de 25 de junho de 2002 que regulamenta a Lei $n^{0}$ 9.795, de 27 de abril de 1999 traz diretrizes sobre a Política Nacional de Educação Ambiental (BRASIL, 2002).

\section{Conferência intergovernamental sobre educação ambiental aos países membros}

Em 1977 foi realizada a Conferência Intergovernamental de Educação Ambiental em Tbilisi, capital da Geórgia, Comunidade dos Estados Independentes - CEI (Ex-URSS) organizada pela UNESCO (Organização das Nações Unidas para a Educação, a Ciência e a Cultura) com a colaboração do PNUMA Programa das Nações Unidas para o Meio Ambiente, do qual o Brasil é signatário, é dirigido a todos os grupos de idade e categorias profissionais que de alguma forma incidem sobre a qualidade do meio ambiente e aos técnicos e cientistas cujas pesquisas e práticas especializadas constituirão a base de conhecimentos sobre os quais deve sustentar-se uma educação, uma formação e uma gestão eficaz, relativa ao ambiente (MEC, 2012 e MATTIOLO et al, 2009).

\section{Tratado de Educação Ambiental para Sociedades Sustentáveis e Responsabilidade Global - TEASS}

O Tratado de Educação Ambiental para Sociedades Sustentáveis e Responsabilidade Global (TEASS), foi elaborado na sua versão final durante a Jornada de Educação Ambiental, no Fórum Global das Organizações não- 
Governamentais, que ocorreu paralelamente à Conferência das Nações Unidas para o Meio Ambiente, no Brasil, na cidade do Rio de Janeiro, em 1992. O Brasil é um dos países signatários do TEASS.

O TEASS está comprometido com o papel central da educação na formação de valores e na ação social. Abaixo estão os princípios do TEASS que são utilizados em vários programas de educação ambiental.

A educação é um direito de todos; somos todos aprendizes e educadores. A educação ambiental deve ter como base o pensamento crítico e inovador, em qualquer tempo ou lugar, em seus modos formal, não-formal e informal, promovendo a transformação e a construção da sociedade. A educação ambiental é individual e coletiva. Tem o propósito de formar cidadãos com consciência local e planetária, que respeitem a autodeterminação dos povos e a soberania das nações. A educação ambiental não é neutra, mas ideológica. É um ato político. A educação ambiental deve envolver uma perspectiva holística, enfocando a relação entre o ser humano, a natureza e o universo de forma interdisciplinar. A educação ambiental deve estimular a solidariedade, a igualdade e o respeito aos direitos humanos, valendo-se de estratégias democráticas e da interação entre as culturas. A educação ambiental deve tratar as questões globais críticas, suas causas e inter-relações em uma perspectiva sistêmica, em seu contexto social e histórico. Aspectos primordiais relacionados ao desenvolvimento e ao meio ambiente, tais como população, saúde, paz, direitos humanos, democracia, fome, degradação da flora e fauna, devem ser abordados dessa maneira (MEC, 2012a).

\section{Objetivos do milênio}

Em setembro de 2000, 189 nações firmaram um compromisso para combater a extrema pobreza e outros males da sociedade. Esta promessa acabou se concretizando nos 8 Objetivos de Desenvolvimento do Milênio (ODM) que deverão ser alcançados até 2015 (PNUD, 2012). São eles:

1 - Acabar com a fome e a miséria

2 - Educação básica de qualidade para todos

3 - Igualdade entre sexos e valorização da mulher

4 - Reduzir a mortalidade infantil

5 - Melhorar a saúde das gestantes 
6 - Combater a Aids, a malária e outras doenças

7 - Qualidade de vida e respeito ao meio ambiente

8 - Todo mundo trabalhando pelo desenvolvimento

\section{Agenda 21}

O capítulo $\mathrm{n}^{\circ} 36$ da Agenda 21, referente à educação, tem como base a Declaração e as Recomendações da Conferência Intergovernamental de Tbilisi sobre educação ambiental (organizada pela UNESCO e o PNUMA) e propõe que exista um esforço global para fortalecer atitudes, valores e ações ambientalmente saudáveis e que apoiem o desenvolvimento sustentável por meio da promoção do ensino, da conscientização e do treinamento. No item Aumento da Conscientização Pública - Base para a Ação - deste capítulo citamos: “...é necessário sensibilizar o público sobre os problemas de meio ambiente e desenvolvimento, fazê-lo participar de suas soluções, fomentar o senso de responsabilidade pessoal em relação ao meio ambiente e uma maior motivação e dedicação em relação ao desenvolvimento sustentável" (MMA, 2012).

Além dos treinamentos mencionados acima, neste trabalho está sendo proposta a utilização de treinamentos em gestão de pessoas. Uma inovação em termo de Sistema de Gestão Ambiental, que auxiliará o aprendizado como um todo, pois permitirá o estabelecimento de metas, mudanças de hábitos, crenças, além de contribuir para que o funcionário (cidadão) realize suas tarefas com profissionalismo e ética não só no ambiente de trabalho.

CAMARGO (1999) diz que "a ética profissional é a aplicação da ética geral no campo das atividades profissionais; a pessoa tem que estar imbuída de certos princípios ou valores próprios do ser humano para vivência nas suas atividades de trabalho". Quando a ética está presente na pessoa, ela atua de forma a contribuir com a ética empresarial no cotidiano do colaborador.

O desenvolvimento ético de uma empresa depende das pessoas que farão parte dela e buscarão o mesmo objetivo, baseando-se nos mesmos valores (DERETTE, 2011). A ética deve fazer estar presente na cultura organizacional da empresa, sendo disseminada em todos os seus níveis hierárquicos. A cultura organizacional se refere a um sistema de valores, compartilhado pelos membros, de uma organização e que a difere de uma para outra. Esse sistema é, em última 
análise, um conjunto de características-chave que a organização valoriza (ROBBINS, 2002).

A existência de normas, legislações, procedimentos e mesmo de um Sistema de Gestão Ambiental não garante que os funcionários irão segui-los. A decisão está nas "mãos" do indivíduo (profissional, colaborador) comprometido com o meio ambiente.

As mudanças efetuadas em cada indivíduo com os treinamentos em gestão pessoal permitirão a sedimentação ou desenvolvimento de valores no funcionário, que uma vez adquiridos, serão cidadãos conscientes para exercerem estas qualidades onde estiverem.

Existem vários treinamentos em gestão de pessoas e estão sendo sugerida a utilização de duas ferramentas utilizadas no ambiente corporativo: a programação neurolinguística e o coaching, que abaixo serão abordadas com mais detalhes. E posteriormente, com o surgimento de novas técnicas, outras poderão ser acrescidas aos treinamentos.

Esta última modalidade de treinamento permitirá um melhor aprendizado dos treinamentos: específicos, do SGA e os referentes à educação ambiental.

A palavra coaching tem sido associada ao esporte, ou seja, ao técnico que treina a equipe para que juntos atinjam suas metas em diferentes competições. Muitos motivos justificam o interesse pela utilização desta metodologia, mas o principal é que ela contribui diretamente para a aquisição e amadurecimento de competências, adaptação aos processos de transformação organizacional com melhoria de desempenho (MILARÉ, 2004).

MILARÉ (2004) pode verificar a evidência científica sobre sua eficiência. Esta técnica utiliza várias ferramentas para que estes objetivos sejam alcançados.

A neurolinguística, ou programação neurolinguística - PNL é um conjunto de técnicas que visa basicamente ao desenvolvimento pessoal. Ela é baseada na ideia de que a mente, o corpo e a linguagem interagem para criar a percepção que cada indivíduo tem do mundo, e que essa percepção pode ser alterada pela aplicação de uma variedade de técnicas. A base de tais técnicas é chamada de "modelagem" e envolve a reprodução cuidadosa dos comportamentos e crenças daqueles que atingiram o sucesso pessoal e profissional. As empresas estariam inserindo as ferramentas da PNL em seus programas de qualidade por entender 
que elas podem ser aplicadas com eficácia como técnicas de persuasão e motivação. A PNL ajudaria no desenvolvimento de carreiras, na formação de equipes, na tomada de decisões e nos conflitos de interesses. Buscaria melhorar a comunicação interna e as negociações externas, pois ensina a influenciar as pessoas utilizando a linguagem (BENELLI, 2009).

No APÊNDICE B é apresentado o documento elaborado neste trabalho, que atende ao item de Treinamento e Conscientização da Norma ABNT NBR ISO 14001 (ABNT, 2004).

\subsubsection{Comunicação}

Os canais de comunicações internas disponíveis são: intranet, o Boletim Semanal - BS, quadros murais, mala direta eletrônica, palestras, a Semana Interna de Prevenção de Acidentes no Trabalho - SIPAT e os canais de comunicações externas são: internet (canais abertos para partes interessadas), palestras e publicações em revistas, jornais e folhetos da Marinha do Brasil e outras instituições. Na comunicação externa poderá ser ressaltada a importância da USEXA no Programa Nuclear da Marinha e também utilizar este mecanismo para abordar as questões sobre a educação em "energia nuclear".

A prioridade às respostas deve ocorrer nos seguintes casos: reclamações de partes interessadas; e comunicações que tiverem origem em um órgão de controle ambiental (CNEN, IBAMA, CETESB, MARINHA - IAM, DICOM, DPC) e nestes casos o CTMSP tem um setor de Licenciamento Ambiental que atende aos questionamentos dos órgãos de controle ambiental; e comunicações que proporcionam uma oportunidade de melhoria para o SGA.

O grupo interessado externo (o público em geral ou internamente) deve receber informações relativas ao meio ambiente, necessárias à compreensão da contribuição da USEXA, sendo importante a construção de um diálogo aberto entre as partes.

\subsubsection{Documentação do SGA}

Todos os documentos confeccionados na implantação e operação do SGA na USEXA deverão seguir os Procedimentos Sistêmicos elaborados pelo Departamento de Garantia da Qualidade do CTMSP para implantação do Sistema 
da Qualidade, e muitos deverão passar por revisões para adequação ao Sistema de Gestão Ambiental.

O Manual de Gestão Ambiental da USEXA será o principal documento do sistema. Este Manual deverá apresentar de forma sucinta os processos e métodos utilizados na implantação e manutenção do SGA.

A elaboração do Manual foi uma das metas deste trabalho e é apresentado no APÊNDICE C.

\subsubsection{Controle de documentos e registros}

Os controles dos documentos e registros deverão ser realizados pela USEXA para orientar o cumprimento da sua Política Ambiental, dos demais requisitos da ABNT NBR ISO 14001 (ABNT, 2004) e da legislação vigente.

No Manual da Qualidade do CTMSP, 2004 são apresentadas diretrizes sobre emissão, liberação, distribuição, revisão, arquivamento, cancelamento e disposição final dos documentos, além de outras providências. Se necessário a USEXA deverá adequá-lo ao Sistema de Gestão Ambiental, com o apoio da Divisão de Gestão Ambiental e do Comitê Ambiental do CTMSP, setores responsáveis pela implantação e manutenção do SGA.

\subsubsection{Preparação e resposta à emergência}

A USEXA deverá estabelecer, implementar e manter procedimentos que descrevam potenciais riscos ambientais, bem como descrever as ações e as responsabilidades para atender às situações de emergência e aos acidentes. Estes procedimentos deverão ser periodicamente analisados e revisados, quando necessário, sobretudo após a ocorrência de algumas destas situações.

\subsection{Verificação}

\subsubsection{Monitoramento e medição}

Deverá ser elaborado e implementado um Plano de Monitoramento e Medições que inclua a verificação do desempenho ambiental, o cumprimento dos objetivos e metas ambientais estabelecidas no Plano Gestão Ambiental - PGA, bem como verificar o nível de atendimento aos requisitos legais e normas ambientais aplicáveis. 
A USEXA deverá estabelecer procedimentos para as etapas de lançamento, monitoramento e medição de efluentes, resíduos e rejeitos liberados em seus processos, antes de serem monitorados pelo LARE e enviados para 0 futuro Sistema de Tratamento de Efluentes de Aramar - SITEA (em fase de montagem eletromecânica).

O CTMSP como um todo e também a USEXA, conta com o LARE Laboratório Radioecológico que basicamente tem duas atribuições: controlar os efluentes que são liberados para o meio externo do CEA; e averiguar se este controle está sendo eficiente através da monitoração de amostras ambientais.

Para desempenhar suas funções, o LARE desenvolve o Programa de Monitoração Ambiental - PMA aprovado pela CNEN, que promove coletas em 56 pontos de amostragem distribuídos num raio de $10 \mathrm{~km}$ a partir do CEA. São coletadas amostras de água do rio, água de chuva e de poços, particulados do ar, solo, peixes, produtos agrícolas, leite, sedimentos do rio e é medida a radiação direta. Esse Programa se compõe, na realidade, de dois subprogramas:

- Programa de Monitoração Radiológica, onde é avaliada a possibilidade de contaminação radiológica do indivíduo do público e são feitas as seguintes análises nas diversas amostras ambientais: determinação de emissores alfa, beta e gama; dosimetria termoluminescente e urânio por meio da fluorimetria; e

- Programa de Monitoração não Radiológica, consistindo de análise da qualidade das águas de mananciais, precipitação pluviométrica e água subterrânea. Nessas amostras são realizadas determinação de metais tóxicos, sódio, potássio, pH, oxigênio dissolvido, DBO, DQO, amônia, fosfato, nitrato e outros parâmetros que constam da Resolução CONAMA n 357 (CONAMA, 2005), onde são estabelecidos padrões de qualidade dos recursos hídricos (CTMSP, 2011f).

A USEXA deverá elaborar um plano de monitoração de processos e de calibração dos equipamentos de monitoramento e medição, prevendo inclusive a utilização de laboratórios de metrologia externos, estabelecendo critérios como acreditação em órgãos oficiais, atendimento a ABNT NBR ISO/IEC 17025 (ABNT, 2005a). 


\subsubsection{Avaliação do atendimento a requisitos legais e outros}

Para a identificação dos requisitos legais deverá ser utilizado o Procedimento PR-CTMSP-SGA-03_00 (CTMSP, 2004), já existente no CTMSP.

A USEXA deverá ter mecanismos de atualizar periodicamente as legislações e normas vigentes aplicáveis em seus processos, inclusive atendendo às Normas Técnicas Ambientais emitidas pela DPC. Esta atualização periódica poderá ser obtida pelo setor de implantação do SGA do CTMSP, ou por empresa especializada. Sempre que houver a publicação de legislações e normas que se apliquem as atividades desenvolvidas na USEXA, as planilhas de avaliação de aspectos e impactos deverão ser revisadas.

\subsubsection{Não conformidade, ação corretiva e ação preventiva}

A USEXA utilizará como base o Procedimento $\mathrm{n}^{\circ}$ PR-CTMSP-NCF-01 (CTMSP, 2012), emitido pelo Departamento de Garantia da Qualidade do CTMSP, para identificação de não conformidade e para as ações corretivas e preventivas o Procedimento $\mathrm{n}^{\circ}$ PR-CTMSP-ACP-01 (CTMSP, 2008). Ambos procedimentos estão sendo revistos para adequação ao SGA.

As não conformidades geradas no Sistema de Garantia da Qualidade são gerenciadas por um Banco de Dados que também fará o gerenciamento das não conformidades ambientais.

\subsubsection{Indicadores de desempenho}

Os indicadores de desempenho são uma das fases mais importantes da etapa de avaliação do SGA pois permite avaliar os resultados alcançados, quanto ao grau de implementação do SGA e eficácia das ações, deve ser feita regularmente pela Gerência da USEXA, em conjunto com as várias áreas técnicas e gerenciais. Com base nas metas fixadas no Plano de Ação e nos procedimentos estabelecidos, devem ser fixados os indicadores de desempenho aplicáveis (MOURA, 2008). Abaixo alguns exemplos:

- consumo de energia elétrica (em MWh por ano);

- consumo de água (em $\mathrm{m}^{3}$ por ano);

- geração de resíduos (em t por ano)

- percentagem de metas atingidas; 
- número de não conformidades por ano, identificadas em auditorias;

- número de ações corretivas por ano;

- percentagem de funcionários treinados em questões ambientais;

- satisfação dos funcionários (avaliada com base em pesquisas de opinião)

Vinculada à Superintendência da Qualidade e Segurança Nuclear, a Assessoria de Gestão Organizacional administra uma base de dados relativos às principais atividades do CTMSP, a partir das informações fornecidas pelas Unidades Organizacionais (UO). Também assessora as UO na elaboração, atualização e divulgação dos indicadores institucionais alinhados ao Plano Estratégico e ao Plano de Melhoria de Gestão do CTMSP.

\subsubsection{Auditoria interna e análise pela administração}

Além dos funcionários da própria USEXA que terão competência para a realização de auditorias internas, a USEXA poderá solicitar auxílio para a Auditoria Líder do CTMSP, subordinada à Superintendência da Qualidade e Segurança Nuclear, pois é responsável por atividades relacionadas a auditorias internas e análise pela administração. As auditorias deverão ser planejadas e executadas conforme documento próprio, segundo ABNT NBR ISO 19011 (ABNT, 2012).

\subsubsection{Processo de acreditação}

A DPC é responsável pelas diretrizes de implantação dos Sistemas de Gestão Ambiental na Marinha do Brasil, após avaliação quanto à importância do processo de acreditação para a Organização Militar - OM em questão, em virtude do alto custo envolvido em todo o processo e manutenção da acreditação junto a órgãos acreditadores. 


\section{DISCUSSÃO}

O CTMSP é uma instituição que faz parte do Programa Nuclear Brasileiro e é uma instalação científica que desenvolve tecnologia genuinamente nacional, a implementação do Sistema de Gestão Ambiental proposto, atende ao Decreto-lei no 1.809 (BRASIL, 1980) que institui o Sistema de Proteção ao Programa Nuclear Brasileiro - SIPRON, em seu Artigo $1^{\circ}$ decreta que: “... a execução continuada de providências que visem a atender às necessidades de segurança do Programa Nuclear Brasileiro e de seu pessoal, bem como da população e do meio ambiente com ele relacionados" e a Lei no 9.605 (BRASIL, 1998) que dispõe sobre as sanções penais e administrativas derivadas de condutas e atividades lesivas ao meio ambiente, e dá outras providências. Na sua Seção $n^{\circ}$ IV (Dos Crimes contra o Ordenamento Urbano e o Patrimônio Cultural) no artigo $\mathrm{n}^{\circ} 62$ menciona que é crime "Destruir, inutilizar ou deteriorar: I - bem especialmente protegido por lei, ato administrativo ou decisão judicial; e II - arquivo, registro, museu, biblioteca, pinacoteca, instalação científica ou similar protegido por lei, ato administrativo ou decisão judicial".

O SGA proposto atende a Resolução CONAMA nº 237 (CONAMA, 1997), que considera a necessidade de se incorporar ao sistema de licenciamento ambiental os instrumentos de gestão ambiental, visando ao desenvolvimento sustentável e à melhoria contínua. Em seu artigo $4^{\circ}$ descreve: "compete ao Instituto Brasileiro do Meio Ambiente e dos Recursos Naturais Renováveis IBAMA, o licenciamento ambiental, de empreendimentos e atividades com significativo impacto ambiental de âmbito nacional ou regional"; e no item $\mathrm{n}^{\circ}$ IV deste mesmo artigo inclui dentre as atividades as: "destinadas a pesquisar, lavrar, produzir, beneficiar, transportar, armazenar e dispor material radioativo, em qualquer estágio, ou que utilizem energia nuclear em qualquer de suas formas e aplicações, mediante parecer da Comissão Nacional de Energia Nuclear CNEN".

No início da implantação do Sistema de Gestão Ambiental no CTMSP, em 2002, optou-se por um SGA único, tanto para a Sede (localizada em São Paulo) quanto para o CEA (Iperó, município de São Paulo). Neste trabalho foi proposto 
que seja implantado um SGA para cada unidade (UO) do CTMSP, pois desta forma a definição dos objetivos, metas e programas são melhores estabelecidos para atender às peculiaridades de cada setor. Como visto neste trabalho, a USEXA caracteriza-se em impactos relacionados mais com as características químicas das substâncias, do que os aspectos radiológicos, como não é o caso de outras unidades. Apenas os documentos comuns do Sistema de Gestão Ambiental seriam compartilhados por todas as unidades do CTMSP.

Pode-se dizer que o CTMSP é uma empresa pública, militar e desenvolve suas atividades na área nuclear e cada um destes seguimentos possui "cultura" bem definida, com legislações e órgão reguladores próprios. Este trabalho agregou diretrizes modernas para a implantação de um Sistema de Gestão Ambiental no Ciclo do Combustível Nuclear.

As normas da CNEN e da AIEA recomendam itens de segurança dentro do contexto de proteção das pessoas e do meio ambiente contra os efeitos nocivos da radiação ionizante.

OLIVEIRA (2008), conclui em seu trabalho que além de compostos de urânio, as plantas de conversão de $U_{6}$, manuseiam e processam grande quantidade de produtos químicos perigosos, que podem ser tóxicos, corrosivos, combustíveis e explosivos e por isso também apresentam riscos ao pessoal do sitio e ao meio ambiente. Também conclui que a análise de segurança deste tipo de planta deve considerar também os impactos decorrentes dos produtos químicos e dos perigos decorrentes dos processos industriais, que não são tratados pelos projetos de normas de segurança da AIEA.

Neste trabalho é apresento uma proposta de Sistema de Gestão Ambiental e o Manual do SGA para a USEXA, complementando as lacunas deixadas pelas recomendações das normas da CNEN e da AIEA.

Pode se verificar neste trabalho e no trabalho de MARIN (2005) que os impactos ambientais mais significativos estão associados em especial aos impactos químicos.

OLIVEIRA (2008) destaca em seu trabalho que o então projeto de norma Safety of fuel cycle facilities - Safety requirements - DS344 que hoje é a norma de segurança Safety of Conversion Facilities and Uranium Enrichment Facilities SSG 5 (IAEA, 2012) expõe algumas características distintas das plantas de 
conversão, tais como: o material radioativo utilizado na planta possui radiotoxidade relativamente baixa, mas com potencial de gerar impactos químicos e toxicológicos aos trabalhadores, ao público e ao meio ambiente, devido:

1) à grande quantidade de $\mathrm{UF}_{6}$, aos produtos de reação $\left(\mathrm{UO}_{2} \mathrm{~F}_{2}, \mathrm{HF}\right.$ ) associados com a operação de $U_{6}$ líquido e a estocagem e manuseio de grande quantidade de compostos de urânio sólido;

2) as condições para incêndio e explosões que resultem em liberação radiológica são potenciais, como aquelas decorrentes da explosão de $\mathrm{H}_{2}$ nos fornos de redução; e

3) os riscos químicos são significativos devido à grande quantidade de HF anidro e amônia $\left(\mathrm{NH}_{3}\right)$ que estão presentes no processo.

E como consequência, recomenda focar atenção nas seguintes situações de risco: liberação de $\mathrm{HF}, \mathrm{NH}_{3}$ e $\mathrm{UF}_{6}$; incêndio de grandes proporções em razão do $\mathrm{H}_{2}$ ou solventes; e explosão no processo de redução com $\mathrm{H}_{2}$.

Também segundo OLIVEIRA (2008), dos três primeiros tipos de riscos acima citados, o segundo risco, de acordo com o projeto de norma e atual norma de segurança da IAEA (2012), é o de maior significância com relação à segurança, pois resultam em consequências químicas e radiológicas aos trabalhadores, dentro do sítio, e podem resultar também em algumas consequências adversas fora do sítio, assim como ao meio ambiente.

Como as plantas processam apenas urânio natural, não há risco de ocorrer criticalidade. Neste caso, a radiotoxidade é baixa sendo limitada a possibilidade de ocorrer consequências radiológicas externas. Além disso, a toxidade química do urânio na forma solúvel, como $0 U F_{6}$, é mais significativa do que a sua radiotoxidade (IAEA, 2012).

Pode-se verificar que estes principais impactos foram previstos neste trabalho, sendo elencados como os principais objetivos, metas e programas sugeridos.

MARIN (1999) também conclui em sua dissertação de mestrado que neste tipo de planta os perigos maiores estão associados a substâncias químicas convencionais $\left(\mathrm{NH}_{3}, \mathrm{HF}, \mathrm{HNO}_{3}\right)$ e não ao $\mathrm{UF}_{6}$ produzido, pois para a situação mais provável de liberação de $U_{6}$, as consequências atingem distâncias de 1600 metros, ao passo que para outras situações (isto é, para o $\mathrm{NH}_{3}, \mathrm{HF}$ e $\mathrm{HNO}_{3}$ ) as 
distâncias de impacto podem superar 40.000 metros (para planta analisada pelo autor).

MARIN (1999) aponta ainda em sua pesquisa outros eventos que podem ocorrer nestes tipos de plantas:

1) na produção de flúor, a ocorrência de explosão nas células eletrolíticas por polarização do ânodo, corrosão das conexões, hipolarização do diafragma, desequilíbrio de pressão entre os compartimentos anódicos e catódicos; e

2) no processo de purificação, incêndio na área de extração com solvente pelo derramamento do conteúdo da coluna de extração; e nos processos que geram rejeitos líquidos (dissolução, precipitação e purificação), rompimento das bacias de contenção causando danos ao meio ambiente com radionuclídeos.

O mesmo autor elaborou um projeto de dissertação sobre "Análise de Perigos em uma Instalação de Produção de Hexafluoreto de Urânio", utilizando como base para o projeto a planta "Kerr Mc Sequoyah Hexafluoride Plant" (Kerr), dos Estados Unidos da América, que foi descomissionada em 1996. Da mesma forma como a planta caracterizada nesta pesquisa, a planta "Kerr" utilizava os processos de purificação por via úmida e o de hidrofluoração por via seca, utilizando HF anidro. Entretanto, as plantas se diferem quanto aos processos utilizados para transformação do NTU (puro) em $\cup_{3}$. Enquanto a "Kerr" utilizava o processo de denitração térmica (calcinação), a planta desta pesquisa se refere ao processo de precipitação do DUA, seguido de sua calcinação.

A implantação de um SGA permite também a abordagem de aspectos e impactos ambientais, como a geração de resíduos sólidos e o consumo de água e energia, sem importância relevante nas normas que tratam de instalações nucleares.

Os aspectos e impactos ambientais apresentados neste trabalho, foram identificados com base no Relatório de Análise de Segurança, elaborado em 2001, no trabalho de MARIN (2005) sobre Análise de Riscos e Avaliação de Impacto Ambiental em uma Instalação de Processamento Químico e em entrevistas realizadas ao longo do trabalho com os responsáveis pela USEXA. Esta forma de levantamento de dados, denominada aqui de "prognóstico" (uma vez que a USEXA está em fase de comissionamento) mostrou-se eficaz na determinação de objetivos, metas e programas. 
A implantação de um SGA é baseada no ciclo PDCA, o qual prevê constantes melhorias e este trabalho deverá ser revisto quando a USEXA entrar em plena operação, sobretudo deverão ser revistas as planilhas de aspectos e impactos ambientais, pelos responsáveis técnicos da USEXA, uma vez que alguns processos descritos neste trabalho podem não representar a operação real. O alcance dos objetivos deste trabalho não foi comprometido por este fato, pois as diretrizes sugeridas para implantação de um SGA serão as mesmas. Comparando-se esta proposta a uma edificação, as diretrizes propostas seriam as "bases e as colunas" do edifício e o "prognóstico realizado" o tipo de argamassa utilizada para o preenchimento, ou seja, pode ser alterada conforme o objetivo da edificação.

Pode-se dizer que este trabalho contribuiu para atualização das informações contidas no Relatório Preliminar de Análise de Segurança da USEXA, emitido em 2001.

A apresentação de Estudos de Impacto Ambiental - EIA e dos Relatórios de Impactos Ambientais - RIMA, na fase de licenciamento de um empreendimento, possibilitam um olhar "da porta da fábrica para fora" e a implementação de um Sistema de Gestão Ambiental ampliar esta interface trazendo uma visão "da porta da fábrica para dentro".

A Planilha de Avaliação de Aspectos Ambientais, apresentada por MATTIOLO et al (2011) e aplicada neste trabalho é eficaz na avaliação de impactos ambientais, uma vez que considera a localização de cada unidade como fator importante para priorização dos mesmos. A localização do empreendimento faz diferença para gerenciamento dos impactos, uma vez que, por exemplo, não pontua de maneira igual a emissão de efluentes líquidos, ou resíduos, em área urbana e rural. Este princípio se aplica no CTMSP, uma vez que o CEA fica em área rural e a Sede em área urbana com legislações diferenciadas. Esta planilha pode ser utilizada na implantação de qualquer SGA, quando a empresa em questão tiver filial com localizações diferenciadas, inclusive em outros países.

O que motiva a maioria das empresas a iniciarem um sistema de gestão, na maioria das vezes é a melhoria nos lucros da empresa. MOURA, 2002 deixa claro que as metas do SGA são facilmente alcançadas quando as empresas dependem da "sua imagem" para se relacionarem com seus clientes e partes 
interessadas. A demonstração do desempenho ambiental é cultuada, quando envolve consumidores de produtos e serviços.

No caso da implantação de um SGA em empresa pública, como é o caso do CTMSP e mais especificamente a USEXA, foco deste estudo, o "cliente" que seria a mola propulsora do processo, não está bem definido, sem a meta de melhorias no lucro. Desta forma há necessidade de estar bem definido, para todos os "atores" do processo, que o meio ambiente e consequentemente as próprias pessoas em conjunto com os órgãos legisladores são os clientes em empresas públicas. Este conceito deve ser bem disseminado na educação ambiental.

A Resolução CONAMA nº 237 (CONAMA, 1997) considera, dentre outras, a necessidade de se incorporar ao sistema de licenciamento ambiental os instrumentos de gestão ambiental, visando ao desenvolvimento sustentável e à melhoria contínua.

A implantação de um SGA permite organizar a documentação para obtenção das licenças junto ao IBAMA e à CNEN. O Programa de Educação Ambiental, previsto no SGA, atualmente é uma condicionante para renovação das licenças ambientais do CTMSP.

No APÊNDICE B, deste trabalho, foram apresentadas Diretrizes para Treinamento e Conscientização em educação e psicologia ambiental e gestão de pessoas.

Segundo MOURA (2002) é fundamental que exista na empresa uma conscientização adequada quanto a importância da questão ambiental para 0 sucesso dos seus negócios. O nível de conscientização e conhecimento adequado ao problema, e da importância do cumprimento da política ambiental e exigências de um sistema de gestão ambiental, deverá ser proporcionado por meio dos treinamentos.

O mesmo autor define que a conscientização está ligada à motivação, ou seja, a vontade que as pessoas têm em realizar seus trabalhos da melhor maneira possível, ao passo que o treinamento refere-se a preparar as pessoas para que elas bem desempenhem suas funções. Resumindo, a conscientização diz respeito a "querer fazer", ao passo que o treinamento a "saber fazer". 
As ferramentas de gestão de pessoas, sugeridas neste trabalho (coaching e PNL) contribuem sobremaneira para a conscientização e treinamento de pessoas. Outras técnicas utilizadas em gestão de pessoas poderão ser agregadas a esta proposta.

Segundo MILARÉ (2004) muitos motivos justificam o interesse pela utilização do coaching em gestão de pessoas, mas o principal é que ela contribui diretamente para a aquisição e amadurecimento de competências, adaptação aos processos de transformação organizacional com melhoria de desempenho.

A gestão de pessoas juntamente com a educação e psicologia ambiental trazem ferramentas modernas, facilitando não apenas a implantação como a operação do SGA, além de permitir, por meio do desenvolvimento pessoal, a melhoria da interface homem-meio ambiente e a sustentabilidade. A utilização destas ferramentas possibilita que os funcionários se envolvam com o SGA de maneira voluntária e não compulsória como é o caso de empresas que dependem do desempenho ambiental para continuarem no mercado e aumentarem o faturamento.

A Sociedade Brasileira de Programação Neurolinguística (SBPNL, 2012), define PNL como um instrumento que ajuda a entender melhor como o ser humano pensa, age e se comunica, para que cada um seja capaz de identificar e aproveitar suas capacidades para alcançar os resultados que deseja.

SOLEDAD et al (2007) identificaram falhas na ABNT NBR ISO 14001 no que diz respeito à sua contribuição para sustentabilidade ambiental. Os autores comentam que esta norma traz padrões mundiais possibilitando a colocação de um produto ou serviço em um nível comum no mercado mundial, porém não traz a segurança de que as políticas e os programas implementados nesse modelo de gestão asseguram a sustentabilidade ambiental, podendo ser um mero instrumento de marketing.

MATTIOLO et al (2009) propõe que os conceitos oriundos da educação e psicologia ambiental são úteis no auxílio da implementação do SGA. O treinamento aos funcionários é de grande importância, a participação e adesão de todos os atores da instituição são fundamentais para um sistema de sucesso. As mudanças de comportamento e consciência ambiental são, portanto essenciais nesta fase. 
Um dos objetos de estudo da psicologia ambiental, de acordo com CORRAL-VERDUGO \& PINHEIRO (1999), de maior interesse nas últimas três décadas, tem sido o comportamento pró-ambiental (CPA). Essas pesquisas indicam as características das pessoas e as condições que podem estar relacionadas a atitudes e comportamentos ambientalmente responsáveis. Portanto, um comportamento pró-ambiental está ligado com crenças, valores e atitudes individuais, pertencentes ao sistema cognitivo do homem. Desta forma, uma educação voltada para orientação de valores ambientais, cuidado e preservação do ambiente, pode alterar as crenças e atitudes do ser humano e consequentemente, o comportamento (MATTIOLO et al, 2009).

Neste trabalho foi utilizado o conceito inverso, o treinamento em desenvolvimento pessoal para alterar crenças e atitudes e consequentemente alterar os valores ambientais dos envolvidos, modificando suas atitudes não só na empresa, mas no dia-a-dia. As ferramentas de gestão desenvolve nas pessoas o autoconhecimento, a inteligência emocional, mudanças de hábitos e cultura e desta forma os funcionários não terão atitudes ambientalmente corretas para o cumprimento de normas, mas por terem adquirido consciência nas questões ambientais.

O desenvolvimento do funcionário, utilizando as ferramentas da gestão de pessoas, propiciará o seu desenvolvimento social, econômico, além da melhor absorção dos treinamentos propostos (específicos, para implantação do SGA e em educação e psicologia ambiental), pois permitirá pessoas conscientes de seus limites e dos limites do meio ambiente. O funcionário é o ser humano que desempenha outros papéis na sociedade, atuando em casa, no seu bairro, cidade.

Os treinamentos em gestão de pessoas possibilitará que o conceito do ciclo do PDCA, sobre melhoria constante, esteja presente também de forma intrínseca nos atores do processo, pois o processo de melhoria constante estará estabelecido em cada funcionário, por meio de objetivos e metas pessoais. Podese dizer desta forma, que o processo de melhoria constante estará "girando sozinho" no sistema.

A implantação de normas voluntariamente, como é de certa forma, o caso das empresas públicas, requer o comprometimento direto dos seus 
colaboradores, que é facilitado pela utilização das ferramentas como o coaching e PNL, utilizados na gestão de pessoas. A ideia do desempenho pessoal e responsabilidade direta na manutenção da sustentabilidade, despertando-os para o papel desempenhado por cada um dentro das suas funções que atingirão o desenvolvimento pleno do Programa Nuclear Brasileiro, da soberania nacional, e fazer que o CTMSP contribua com os objetivos do Milênio e o cumprimento da Agenda 21.

A existência de legislações, normas e Sistemas de Gestão, seja ela da qualidade ou ambiental, não garantem por si só a manutenção de práticas sustentáveis e sim a ética, os valores intrínsecos de cada um mais o conhecimento e a prática de atitudes ambientalmente corretas. Desta forma, não havendo necessidade de legislações e normas, pois as atitudes e decisões que envolvam as questões ambientais estarão internalizadas.

Segundo MAXIMIANO (2004) para quem adota a perspectiva comportamental, o importante em uma organização é o sistema social. Os sistemas sociais são formados por pessoas e suas necessidades, sentimentos e atitudes, bem como seu comportamento como integrantes de grupos. O sistema social tem tanta ou mais influência sobre o desempenho da organização do que seu sistema técnico, formado por máquinas, métodos de trabalho, tecnologia, estrutura organizacional, normas e procedimentos. No centro do processo administrativo está o ser humano e não o sistema técnico, quando se aplica a visão comportamental: "o ser humano é a medida de tudo". O moderno enfoque comportamental tem dois temas básicos de estudo: as características que diferenciam as pessoas umas das outras; e o comportamento coletivo das pessoas: como integrantes de grupos, de organizações e da sociedade.

A proposta de programas específicos para redução do uso de energia e água permitirá que o CTMSP contribua para que a $7^{\mathrm{a}}$ meta dos objetivos do milênio seja atingida.

AQUINO et al (2008) mencionam que a divulgação científica ganha importância na luta pela erradicação do analfabetismo e da transformação da ciência em cultura.

As recomendações sugeridas neste trabalho, incluindo cursos e treinamentos na área de gestão de pessoas, poderão ser utilizadas em todos os 
Sistemas de Gestão, aplicados no CTMSP, e em outras organizações e empresas.

O investimento realizado em treinamentos pode ser considerado investimentos em ações preventivas, uma vez que o funcionário consciente das suas responsabilidades e treinado previne as falhas em decorrência ao fator humano.

O processo de certificação e manutenção em ISO 14001 é muito oneroso e a Marinha permite a certificação após avaliação. A única OM da Marinha do Brasil que possui certificação ISO 14001 é a Fábrica Almirante Jurandyr da Costa Muller de Campos (FAJCMC), localizada em Campo Grande (RJ), atendendo a exigências dos países exportadores (parte interessada). Essa fábrica é a única na América Latina com capacidade para fabricação de munição de artilharia de grosso e médio calibre, produzindo toda a munição empregada nos navios da Marinha do Brasil. Entretanto, a DPC incentiva a implantação para melhorias no desempenho ambiental das OM.

Os benefícios que um sistema de gestão ambiental proporciona, estão ao longo da sua implantação, operação e melhorias contínuas. Podemos dizer que o objetivo do SGA está no caminho da implantação e operação e não no fim, ou seja, a certificação. 


\section{CONCLUSÕES E CONSIDERAÇÕES FINAIS}

Este trabalho procurou contribuir com o Programa Nuclear Brasileiro no tocante à parte executada pelo Centro Tecnológico da Marinha em São Paulo, não só na construção de um submarino nuclear, como no desenvolvimento de tecnologia para as usinas térmicas na geração de eletricidade, além de agregar outros conceitos à antiga preocupação do CTMSP com o meio ambiente.

As diretrizes apresentadas para implantação de um SGA na USEXA poderão ser aplicadas em outros setores que fazem parte do Ciclo do Combustível Nuclear, outras OM, inclusive servir de base para revisão das normas emitidas pela DPC, em relação à implantação de Sistemas de Gestão Ambiental.

O SGA preenche as lacunas das normas da CNEN e AIEA, uma vez que levam em consideração os impactos ambientais provenientes das substâncias químicas e a sustentabilidade, no processo de fabricação de UF 6 . Isso pode ser considerado uma contribuição original para esse complexo ramo de atividade.

Os treinamentos em gestão de pessoal e as ferramentas sugeridas neste trabalho como o coaching e a PNL trarão benefícios no programa geral de conscientização e treinamentos da USEXA e do CTMSP, além de poderem ser aplicados em qualquer Sistema de Gestão.

A ênfase dada em Conscientização e Treinamento, em qualquer Sistema de Gestão, pode ser considerada como uma ação preventiva, por contribuir para a diminuição dos incidentes relacionados com a manutenção de equipamentos e consequentemente para a redução das ocorrências de impactos ambientais (explosões, incêndios). Além disso, colabora com a produção mais eficiente e com a diminuição de gastos associados com erros humanos. 


\section{TRABALHOS FUTUROS}

As perspectivas de continuidade deste trabalho são recomendadas a seguir:

- Realizar uma correlação entre os itens das normas da CNEN e a NBR ISO 14.001; e

- Colaborar com a implementação das propostas sugeridas neste trabalho na USEXA. 


\section{NORMAS CNEN}

NE-1.11 - Modelo Padrão para Relatório de Análise de Segurança de Usinas de Produção de Hexafluoreto de Urânio Natural, Janeiro de 1983.

NE-1.04 - Licenciamento de Instalações Nucleares, Dezembro de 2002.

NN 1.16 - Garantia da Qualidade para a Segurança de Usinas Nucleoelétricas e Outras Instalações, Abril de 2000.

NE-2.01 - Proteção Física de Unidades Operacionais da Área Nuclear, Abril de 1996.

NE-2.04 - Proteção Contra Incêndio em Instalações Nucleares do Ciclo do Combustível, Outubro de 1997.

NN-2.02- Controle de Materiais Nucleares, Setembro de 1999.

NE-6.06 - Seleção e Escolha de locais para depósitos de rejeitos radioativos, Dezembro de 1989.

NN-6.09- Critérios de aceitação para deposição de rejeitos radioativos de baixo e médio nível de radiação, Setembro de 2002.

\section{NORTAM (Normas Técnicas Ambientais) da MARINHA DO BRASIL}

NORTAM n ${ }^{\circ} 02$ - Sistema de Gestão Ambiental nas Organizações Militares de Terra. Esta Norma Técnica tem como propósito estabelecer normas e procedimentos para a implantação e o acompanhamento do Sistema de Gestão Ambiental (SGA) nas OM de terra da MB, 2003.

NORTAM n 03 - Plano de Emergência Individual (PEI) para as organizações militares de terra.

Tem como propósito estabelecer normas e procedimentos para a elaboração do Plano de Emergência Individual (PEI) e para a coordenação das ações de resposta, nos incidentes de poluição por óleo em águas jurisdicionais brasileiras, das OM de terra da MB, 2003.

NORTAM n 04 - Auditoria Ambiental nas Organizações Militares de Terra. A presente norma tem como propósito estabelecer os requisitos e procedimentos básicos para a realização de auditorias ambientais nas OM de terra da MB, 2003. 
NORTAM nº 06 - Separação dos Resíduos Recicláveis Descartados pelas OM da MB. Estabelecer normas, em cumprimento à determinação do Comandante de Operações Navais, ratificada pelo Comandante da Marinha, para orientar as OM da MB quanto ao estabelecido no Decreto $n^{\circ} 5.940$ (2006). Este decreto institui a separação dos resíduos recicláveis descartados pelos órgãos e entidades da administração pública federal direta e indireta, na fonte geradora, e a sua destinação às associações e cooperativas dos catadores de materiais recicláveis, 2007.

\section{AGÊNCIA INTERNACIONAL DE ENERGIA ATÔMICA - AIEA}

Normas de Sistema de Gestão (SG) e Segurança (elencadas por OLIVEIRA, 2008)

AIEA GS-R-3:2006 - The Management system for facilities and activities - Safety requirements.

AIEA GS-G-3.1:2006 - Application of the management system for facilities and activities - Safety guide.

IAEA DS349 Rev.2007 - Management systems for nuclear facilities

IAEA DS316 Rev.2006 - Safety of fuel cycle facilities - Safety requirements

IAEA DS344 Rev.2006 - Safety of conversion and enrichment facilities (estágio de operação de instalações de conversão do yellowcake em UF6) 
NORMAS E LEGISLAÇÕES APLICÁVEIS ÀS ATIVIDADES DA USEXA

\section{LEGISLAÇÃO FEDERAL (LEIS)}

\begin{tabular}{|c|c|c|c|c|c|c|c|}
\hline Área & 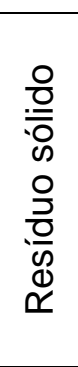 & 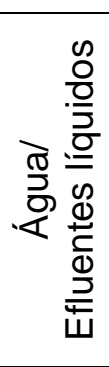 & 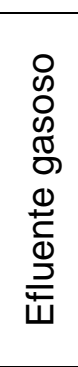 & 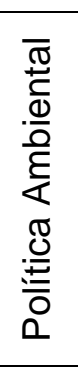 & 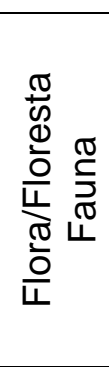 & 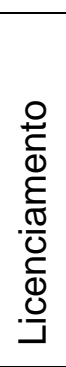 & Resumo \\
\hline $4771-15 / 09 / 1965$ & & & & & $\mathrm{X}$ & & Institui o novo Código Florestal \\
\hline $5197-01 / 01 / 1967$ & & & & & $\mathrm{X}$ & & Dispõe sobre a proteção à fauna \\
\hline $6.938-31 / 08 / 1981$ & & & & $\mathrm{X}$ & & & $\begin{array}{l}\text { Dispõe sobre a Política Nacional do Meio Ambiente, seus fins } \\
\text { e mecanismos de formulação e aplicação. }\end{array}$ \\
\hline $7347-24 / 07 / 1985$ & & & & $\mathrm{X}$ & & & $\begin{array}{l}\text { Disciplina a Ação Civil Pública de responsabilidade por danos } \\
\text { causados ao meio ambiente, ao consumidor, a bens e direitos } \\
\text { de valores artístico, estético, histórico, turístico e paisagístico. }\end{array}$ \\
\hline $9433-08 / 01 / 1997$ & & $\mathrm{X}$ & & & & & $\begin{array}{l}\text { Institui a Política Nacional de Recursos Hídricos, cria o } \\
\text { Sistema Nacional de Gerenciamento de Recursos Hídricos, } \\
\text { regulamenta o inciso XIX do art. } 21 \text { da Constituição Federal, e } \\
\text { altera o art. } 1^{\circ} \text { da Lei no. } 8001 \text {, de 13.03.1990, que modificou } \\
\text { a lei no. } 7990 \text {, de 28.12.1989 }\end{array}$ \\
\hline $9605-12 / 02 / 1998$ & & & & $\mathrm{X}$ & & & $\begin{array}{l}\text { Dispõe sobre as sanções penais e administrativas derivadas } \\
\text { de condutas e atividades lesivas ao meio ambiente }\end{array}$ \\
\hline $9985-18 / 07 / 2000$ & & & & & $\mathrm{X}$ & & $\begin{array}{l}\text { Institui o Sistema Nacional de Unidades de Conservação da } \\
\text { Natureza - SNUC e estabelece critérios e normas para a } \\
\text { criação, implantação e gestão das unidades de conservação. } \\
\text { Altera o art. } 40 \text { e acrescenta o art. } 40-A \text { da Lei } 9605 / 98 \text {. }\end{array}$ \\
\hline $11.428-22 / 12 / 2006$ & & & & & $\mathrm{X}$ & & $\begin{array}{l}\text { Dispõe sobre a utilização e proteção da vegetação nativa do } \\
\text { Bioma Mata Atlântica e dá outras providências. }\end{array}$ \\
\hline
\end{tabular}


NORMAS E LEGISLAÇÕES APLICÁVEIS ÀS ATIVIDADES DA USEXA

\section{DECRETOS}

\begin{tabular}{|c|c|c|c|c|c|c|c|}
\hline Área & 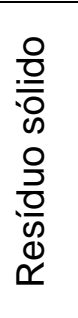 & 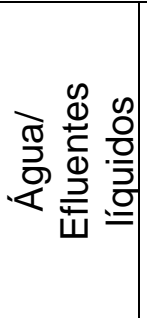 & 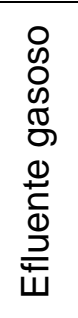 & 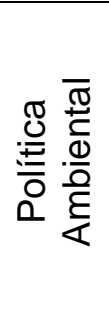 & 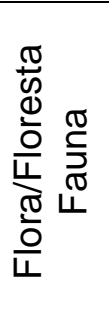 & 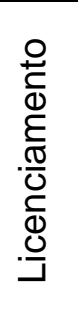 & Resumo \\
\hline $\begin{array}{l}99.274- \\
06 / 06 / 1990\end{array}$ & & & & & & & $\begin{array}{l}\text { Regulamenta a Lei } n^{0} 6.902 \text {, de } 27.04 .81 \text {, e a Lei } n^{0} 6.938 \text {, de } \\
\text { 31.08.1981, que dispõem, respectivamente, sobre a criação e } \\
\text { Estações Ecológicas e áreas de Proteção Ambiental e sobre a } \\
\text { Política Nacional do Meio Ambiente. }\end{array}$ \\
\hline $2.661-08 / 07 / 1998$ & & & & & & & $\begin{array}{l}\text { Regulamenta o parágrafo único do art. } 27 \text { da Lei } \mathrm{n}^{\circ} 4.771 \text {, de } \\
\text { 15.09.1965 (Código Florestal), mediante o estabelecimento de } \\
\text { normas de precaução relativas ao emprego do fogo em } \\
\text { práticas agropastoris e florestais. }\end{array}$ \\
\hline $4.340-22 / 08 / 2002$ & & & & & $\mathrm{X}$ & & $\begin{array}{l}\text { Regulamenta artigos da Lei no } 9985 \text {, de } 18.07 .2000 \text {, que } \\
\text { dispõe sobre o Sistema Nacional de Unidades de } \\
\text { Conservação da Natureza - SNUC }\end{array}$ \\
\hline $5.975-30 / 11 / 2006$ & & & & & $\mathrm{X}$ & & Regulamenta disposições do Código Florestal \\
\hline $5.940-25 / 10 / 2006$ & $\mathrm{X}$ & & & & & & $\begin{array}{l}\text { Institui a separação dos resíduos recicláveis descartados } \\
\text { pelos órgãos e entidades da administração pública federal } \\
\text { direta e indireta }\end{array}$ \\
\hline $6.514-22 / 07 / 2008$ & & & & $\mathrm{X}$ & & & $\begin{array}{l}\text { Dispõe sobre infrações e sanções administrativas ao meio } \\
\text { ambiente estabelecem o processo administrativo federal para } \\
\text { apuração destas infrações }\end{array}$ \\
\hline $6.660-21 / 11 / 2008$ & & & & & $\mathrm{X}$ & & $\begin{array}{l}\text { Regulamenta dispositivos da Lei } 11.428 \text {, de } 22.12 .2006 \text {, que } \\
\text { dispõe sobre a utilização e proteção da vegetação nativa do } \\
\text { Bioma Mata Atlântica }\end{array}$ \\
\hline
\end{tabular}


NORMAS E LEGISLAÇÕES APLICÁVEIS ÀS ATIVIDADES DA USEXA

APÊNDICE A

PORTARIAS FEDERAIS

\begin{tabular}{|c|c|c|c|c|c|c|c|}
\hline Área & 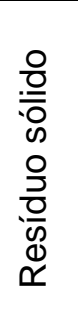 & 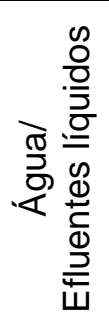 & 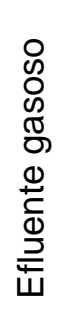 & 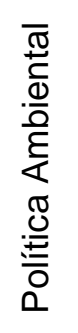 & 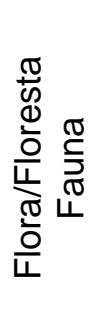 & 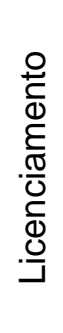 & Resumo \\
\hline $\begin{array}{l}\text { Ministério de } \\
\text { Estado do Interior - } \\
\text { MINTER no } 53- \\
01 / 03 / 79\end{array}$ & $\mathrm{X}$ & & & & & & Tratamento e disposição de resíduos sólidos \\
\hline $\begin{array}{l}\text { MINTER } n^{\circ} 124 \\
20 / 08 / 80\end{array}$ & & & & $\mathrm{X}$ & & & $\begin{array}{l}\text { Localização de depósitos e instalações potencialmente } \\
\text { poluidoras }\end{array}$ \\
\hline
\end{tabular}


NORMAS E LEGISLAÇÕES APLICÁVEIS ÀS ATIVIDADES DA USEXA

APÊNDICE A

\section{RESOLUÇÕES FEDERAIS}

\begin{tabular}{|c|c|c|c|c|c|c|c|}
\hline Área & 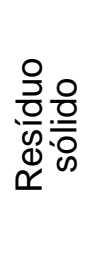 & 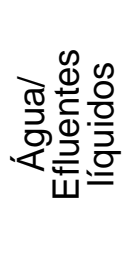 & 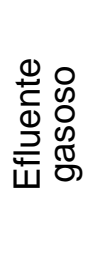 & 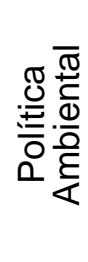 & 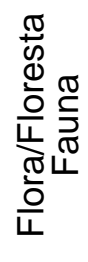 & 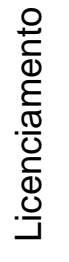 & Resumo \\
\hline $\begin{array}{l}\text { Conselho Nacional de } \\
\text { Recursos Hídricos - } \\
\text { CNRH no 91/ } 2008\end{array}$ & & $\mathrm{X}$ & & & & & $\begin{array}{l}\text { Dispõe sobre procedimentos gerais para o enquadramento dos } \\
\text { corpos de água superficiais e subterrâneos }\end{array}$ \\
\hline $\begin{array}{l}\text { Conselho Nacional do } \\
\text { Meio Ambiente - } \\
\text { CONAMA n }{ }^{\circ} 1,1986\end{array}$ & & & $\mathrm{X}$ & & & $\mathrm{X}$ & $\begin{array}{l}\text { Disciplina o Estudo de Impacto Ambiental - ElA e o Relatório de } \\
\text { Impacto Ambiental - RIMA. Exigências, conteúdo, elaboração, } \\
\text { responsabilidades, audiência publica }\end{array}$ \\
\hline CONAMA n $3 / 1990$ & & & $\mathrm{X}$ & & & & $\begin{array}{l}\text { Estabelece os Padrões de Qualidade do Ar. Padrões primários e } \\
\text { secundários. Plano de emergência para episódios de poluição. }\end{array}$ \\
\hline CONAMA n $5 / 1989$ & & & $\mathrm{X}$ & & & & Institui o Programa Nacional da Qualidade do AR - PRONAR \\
\hline CONAMA n' $8 / 1990$ & & & $\mathrm{X}$ & & & & $\begin{array}{l}\text { Estabelece limites máximos de emissão de poluentes do ar para } \\
\text { processos de combustão externa em fontes novas fixas. }\end{array}$ \\
\hline CONAMA n $9 / 1987$ & & & & & & X & $\begin{array}{l}\text { Complementa a Resolução CONAMA nº 1, de } 23.01 .86 \text { no que se } \\
\text { refere à Audiência Pública. }\end{array}$ \\
\hline CONAMA n 237/1997 & & & & & & $\mathrm{X}$ & $\begin{array}{l}\text { Dispõe sobre licenciamento ambiental; competências da União, } \\
\text { Estados e Municípios; listagem de atividades sujeitas ao } \\
\text { licenciamento; Estudos Ambientais, EIA e RIMA. }\end{array}$ \\
\hline CONAMA n ${ }^{0} 275 / 2001$ & $\mathrm{X}$ & & & & & & Estabelece o código de cores para os diferentes tipos de resíduos \\
\hline CONAMA n $307 / 2002$ & $\mathrm{X}$ & & & & & & $\begin{array}{l}\text { Estabelece diretrizes, critérios e procedimentos para a gestão dos } \\
\text { resíduos da construção civil, disciplinando as ações necessárias de } \\
\text { forma a minimizar os impactos ambientais. }\end{array}$ \\
\hline CONAMA n ${ }^{0} 313 / 2002$ & $\mathrm{X}$ & & & & & & Dispõe sobre o Inventário Nacional de Resíduos Sólidos Industriais \\
\hline CONAMA n ${ }^{0} 357 / 2005$ & & $\mathrm{X}$ & & & & & $\begin{array}{l}\text { Dispõe sobre a classificação dos corpos de água e diretrizes } \\
\text { ambientais para o seu enquadramento, bem como estabelece as } \\
\text { condições e padrões de lançamento de efluentes. }\end{array}$ \\
\hline CONAMA n ${ }^{0} 382 / 2006$ & & & $\mathrm{X}$ & & & & Estabelece os limites máximos de emissão de poluentes atmosféricos \\
\hline
\end{tabular}




\section{NORMAS E LEGISLAÇÕES APLICÁVEIS ÀS ATIVIDADES DA USEXA}

\section{LEGISLAÇÕES FEDERAIS (LEIS)}

\begin{tabular}{|c|c|c|c|c|c|c|c|}
\hline Áreas & 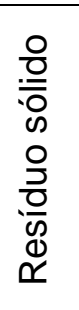 & 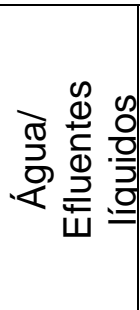 & 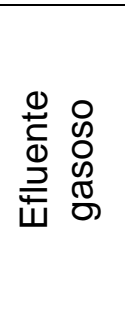 & 畩鸪 & 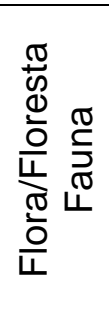 & 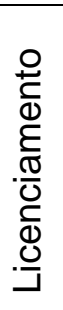 & Resumo \\
\hline $997-31 / 05 / 1976$ & & & & $\mathrm{X}$ & & & $\begin{array}{l}\text { Dispõe sobre o controle da poluição do meio ambiente no } \\
\text { Estado de São Paulo }\end{array}$ \\
\hline $9509-20 / 03 / 1997$ & & & & $\mathrm{X}$ & & & $\begin{array}{l}\text { Dispõe sobre a Política Estadual de Meio Ambiente, seus fins, } \\
\text { mecanismos de formulação e aplicação. }\end{array}$ \\
\hline $10.780-09 / 03 / 2001$ & & & & & $\mathrm{X}$ & & Dispõe sobre a reposição florestal no Estado de São Paulo \\
\hline $10.888-20 / 09 / 2001$ & $\mathrm{X}$ & & & & & & $\begin{array}{l}\text { Dispõe sobre o descarte final de produtos potencialmente } \\
\text { perigosos do resíduo urbano que contenham metais pesados }\end{array}$ \\
\hline $12.183-20 / 12 / 2005$ & & $\mathrm{X}$ & & & & & $\begin{array}{l}\text { Dispõe sobre a cobrança pela utilização dos recursos hídricos } \\
\text { do domínio do Estado de São Paulo }\end{array}$ \\
\hline
\end{tabular}


NORMAS E LEGISLAÇÕES APLICÁVEIS ÀS ATIVIDADES DA USEXA

\section{DECRETOS}

\begin{tabular}{|c|c|c|c|c|c|c|c|}
\hline Áreas & 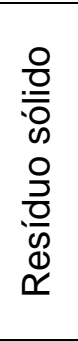 & 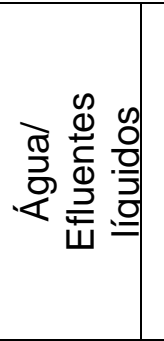 & 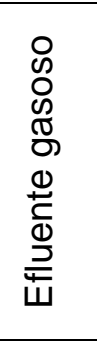 & 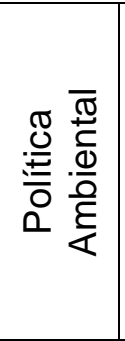 & 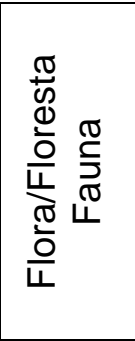 & 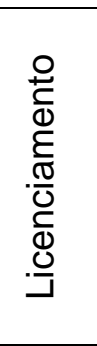 & Resumo \\
\hline $8.468-08 / 09 / 1976$ & & & & $\mathrm{x}$ & & & $\begin{array}{l}\text { Aprova o regulamento da Lei no 997/76, que dispõe sobre o } \\
\text { controle da poluição ambiental no Estado de São Paulo. }\end{array}$ \\
\hline $41.258-31 / 10 / 1996$ & & $x$ & & & & & $\begin{array}{l}\text { Lei } n^{\circ} 7663,9^{\circ} \text { a } 13 \text { da Lei } n^{\circ} 7663 / 91 \text { no que respeita à } \\
\text { outorga de direito de uso dos recursos hídricos. }\end{array}$ \\
\hline $47.400-04 / 12 / 2002$ & & & & & & $\mathrm{X}$ & $\begin{array}{l}\text { Regulamenta dispositivos da Lei no 9509, de } 20 \text { de março de } \\
\text { 1997, referentes ao licenciamento ambiental. }\end{array}$ \\
\hline $49.566-25 / 04 / 2005$ & & & & $x$ & & & $\begin{array}{l}\text { Dispõe sobre intervenção de baixo impacto ambiental em } \\
\text { áreas consideradas de preservação permanente pelo Código } \\
\text { Florestal }\end{array}$ \\
\hline $52.762-28 / 02 / 2008$ & & & & $x$ & & & $\begin{array}{l}\text { Regulamenta a Lei no 10.780/08 que dispõe sobre a reposição } \\
\text { florestal no Estado de São Paulo }\end{array}$ \\
\hline
\end{tabular}


NORMAS E LEGISLAÇÕES APLICÁVEIS ÀS ATIVIDADES DA USEXA

\section{PORTARIAS}

\begin{tabular}{|c|c|c|c|c|c|c|c|}
\hline Áreas & 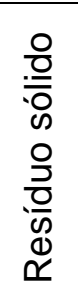 & 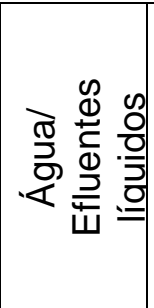 & 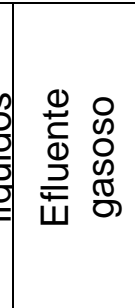 & 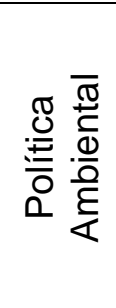 & 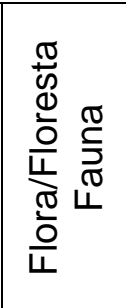 & 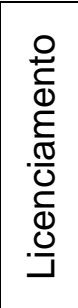 & Resumo \\
\hline $\begin{array}{l}\text { Departamento de } \\
\text { Águas e Energia } \\
\text { Elétrica - DAEE nº } 1 \text {, } \\
\text { de 03/01/1998 }\end{array}$ & & $x$ & & & & & $\begin{array}{l}\text { Aprova normas que disciplinam a fiscalização, as infrações e } \\
\text { as penalidades previstas na Lei no } 7663 / 91\end{array}$ \\
\hline $\begin{array}{l}\text { DAEE } n^{\circ} 717, \text { de } \\
12 / 12 / 1996\end{array}$ & & $x$ & & & & & $\begin{array}{l}\text { Disciplina o uso dos recursos hídricos superficiais e } \\
\text { subterrâneos - outorga }\end{array}$ \\
\hline $\begin{array}{l}\text { Coordenadoria de } \\
\text { Licenciamento } \\
\text { Ambiental e de } \\
\text { Proteção de } \\
\text { Recursos Naturais - } \\
\text { CPRN 4, de } \\
\text { 05/03/2003 }\end{array}$ & & & & & & $\mathrm{X}$ & $\begin{array}{l}\text { Estabelece procedimentos no âmbito da CPRN e seus órgãos } \\
\text { executores, disciplinando a aplicação do disposto no Decreto } \\
\text { Estadual no } 47.400 / 2002\end{array}$ \\
\hline
\end{tabular}


NORMAS E LEGISLAÇÕES APLICÁVEIS ÀS ATIVIDADES DA USEXA

\section{RESOLUÇÕES}

\begin{tabular}{|c|c|c|c|c|c|c|c|}
\hline Areas & 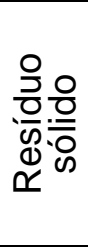 & 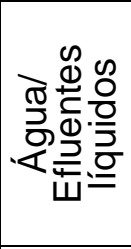 & 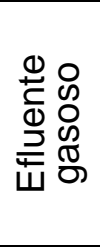 & 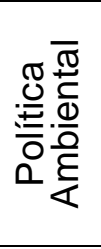 & 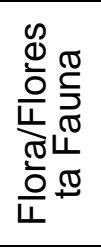 & 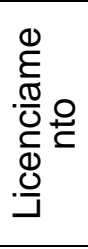 & Resumo \\
\hline $\begin{array}{l}\text { Secretaria do Meio } \\
\text { Ambiente - SMA n } \\
3 / 2000\end{array}$ & & $\mathrm{X}$ & & & & & Controle ecotoxicológico de efluentes líquidos no Est. SP \\
\hline $\begin{array}{l}\text { SMA } n^{\circ} 13- \\
22 / 02 / 2008\end{array}$ & & & & & $\mathrm{X}$ & & $\begin{array}{l}\text { Dispõe sobre a concessão de autorização para a supressão de } \\
\text { vegetação nativa para implantação de obras de interesse público }\end{array}$ \\
\hline $\begin{array}{l}\text { SMA } n^{\circ} 18, \text { de } \\
11 / 04 / 2007\end{array}$ & & & & & $\mathrm{X}$ & & $\begin{array}{l}\text { Disciplina procedimentos para a autorização de supressão de } \\
\text { exemplares arbóreos nativos isolados. }\end{array}$ \\
\hline SMA n²2, de 15/04/09 & & & & & & $\mathrm{X}$ & $\begin{array}{l}\text { Dispõe sobre a apresentação de certidões municipais de uso e } \\
\text { ocupação do solo pelas Prefeituras Municipais nos processos de } \\
\text { licenciamento ambiental. }\end{array}$ \\
\hline $\begin{array}{l}\text { SMA } n^{\circ} 37, \text { de } \\
09 / 12 / 2005\end{array}$ & & & & $\mathrm{X}$ & & & $\begin{array}{l}\text { Define os procedimentos de controle e fiscalização das condutas e } \\
\text { atividades lesivas ao meio ambiente }\end{array}$ \\
\hline SMA n42/2004 & & & & & & $\mathrm{X}$ & Aprova procedimentos de análise de EIA/RIMA no âmbito da SMA \\
\hline SMA n54/2004 & & & & & & $\mathrm{X}$ & $\begin{array}{l}\text { Dispõe sobre procedimentos para o licenciamento ambiental no } \\
\text { âmbito da Secretaria do Meio Ambiente (anexada a SMA 35/2007) }\end{array}$ \\
\hline $\begin{array}{l}\text { SMA/Secretaria de } \\
\text { Energia, Recursos } \\
\text { Hídricos e Saneamento } \\
\text { - SERHS n¹/2005 }\end{array}$ & & & & & & $\mathrm{X}$ & $\begin{array}{l}\text { Regula o procedimento para o licenciamento ambiental integrado às } \\
\text { outorgas de recursos hídricos }\end{array}$ \\
\hline $\begin{array}{l}\text { SMA-SERHS } n^{\circ} 1 \text {, de } \\
22 / 12 / 2006\end{array}$ & & $X$ & & & & & $\begin{array}{l}\text { Dispõe sobre procedimentos integrados para expedição de } \\
\text { retificações ou ratificações dos atos administrativos relativos aos } \\
\text { usos dos recursos hídricos. }\end{array}$ \\
\hline $\begin{array}{l}\text { SMA } n^{\circ} 85, \text { de } \\
11 / 12 / 2008\end{array}$ & & & & & X & & $\begin{array}{l}\text { Dispõe sobre os critérios e parâmetros para compensação } \\
\text { ambiental/objeto de autorização para supressão de vegetação/ESP. }\end{array}$ \\
\hline
\end{tabular}


NORMAS E LEGISLAÇÕES APLICÁVEIS ÀS ATIVIDADES DA USEXA

\section{NORMAS ABNT}

\begin{tabular}{|c|c|c|}
\hline Aplicação & NBR $n^{\circ}$ & Título \\
\hline \multirow[t]{4}{*}{$\begin{array}{c}\text { Efluente líquido } \\
\text { Água }\end{array}$} & 9897:1987 & $\begin{array}{l}\text { Planejamento de amostragem de efluentes } \\
\text { líquidos e corpos receptores }\end{array}$ \\
\hline & 9896:1983 & Glossário de poluição das águas \\
\hline & 13402:1995 & $\begin{array}{l}\text { Caracterização de cargas poluidoras em } \\
\text { efluentes líquidos industriais e domésticos }\end{array}$ \\
\hline & 9898:1987 & $\begin{array}{l}\text { Preservação e técnicas de amostragem de } \\
\text { efluentes líquidos e corpos receptores - } \\
\text { Procedimento }\end{array}$ \\
\hline \multirow[t]{11}{*}{ Efluente gasoso } & 8969:1985 & Poluição do ar - Terminologia \\
\hline & 10700:1989 & $\begin{array}{l}\text { Planejamento de amostragem em dutos e } \\
\text { chaminés de fontes estacionárias - } \\
\text { Procedimento }\end{array}$ \\
\hline & 10702:1989 & $\begin{array}{l}\text { Efluentes gasosos em dutos e chaminés de } \\
\text { fontes estacionárias - Determinação da massa } \\
\text { molecular - Base seca - Método de ensaio }\end{array}$ \\
\hline & $\begin{array}{l}\text { 12020:1992 } \\
\text { Errata 1:1996 }\end{array}$ & $\begin{array}{l}\text { Efluentes gasosos em dutos e chaminés de } \\
\text { fontes estacionárias - Calibração dos } \\
\text { equipamentos utilizados em amostragem. }\end{array}$ \\
\hline & 12827:1993 & $\begin{array}{l}\text { Efluentes gasosos com o sistema filtrante no } \\
\text { interior do duto ou chaminé de fontes } \\
\text { estacionárias - Determinação de material } \\
\text { particulado - Método de ensaio }\end{array}$ \\
\hline & $\begin{array}{l}\text { 12020:1992 } \\
\text { Versão } \\
\text { Corrigida:1996 }\end{array}$ & $\begin{array}{l}\text { Efluentes gasosos em dutos e chaminés de } \\
\text { fontes estacionárias - Calibração dos } \\
\text { equipamentos utilizados em amostragem. }\end{array}$ \\
\hline & 12019:1990 & $\begin{array}{l}\text { NBR Efluentes gasosos em dutos e chaminés } \\
\text { de fontes estacionárias - Determinação de } \\
\text { material particulado - Método de ensaio }\end{array}$ \\
\hline & $12021: 1990$ & $\begin{array}{l}\text { Efluentes gasosos em dutos e chaminés de } \\
\text { fontes estacionárias - Determinação de dióxido } \\
\text { de enxofre, trióxido de enxofre e névoas de } \\
\text { ácido sulfúrico - }\end{array}$ \\
\hline & 12022:1990 & $\begin{array}{l}\text { Efluentes gasosos em dutos e chaminés de } \\
\text { fontes estacionárias - Determinação de dióxido } \\
\text { de enxofre - Método de ensaio }\end{array}$ \\
\hline & 10702:1989 & $\begin{array}{l}\text { Efluentes gasosos em dutos e chaminés de } \\
\text { fontes estacionárias - Determinação da massa } \\
\text { molecular - Base seca - Método de ensaio }\end{array}$ \\
\hline & 11966:1989 & $\begin{array}{l}\text { NBR Efluentes gasosos em dutos e chaminés } \\
\text { de fontes estacionárias - Determinação da } \\
\text { velocidade e da vazão - Método de ensaio }\end{array}$ \\
\hline
\end{tabular}


APÊNDICE A

NORMAS E LEGISLAÇÕES APLICÁVEIS ÀS ATIVIDADES DA USEXA

\begin{tabular}{c|l|l}
\hline & $11967: 1989$ & $\begin{array}{l}\text { Efluentes gasosos em dutos e chaminés de } \\
\text { fontes estacionárias - Determinação da umidade } \\
\text { - Método de ensaio }\end{array}$ \\
\hline \hline Resíduo sólido & $13463: 1995$ & Coleta de resíduos sólidos \\
\hline & $10004: 2004$ & $\begin{array}{l}\text { Resíduos sólidos - Classificação. (Coletânea de } \\
\text { Normas sobre Resíduos Sólidos: ABNT NBR } \\
\text { 10004, ABNT NBR 10005, ABNT NBR 10006 e } \\
\text { ABNT NBR 10007) } \\
\text { Procedimento para obtenção de extrato lixiviado } \\
\text { de resíduos sólido } \\
\text { Procedimento para obtenção de extrato } \\
\text { solubilizado de resíduos sólidos } \\
\text { Amostragem de resíduos sólidos }\end{array}$ \\
\hline $10005: 2004: 2004$ & $\begin{array}{l}\text { Líquidos livres - Verificação em amostra de } \\
\text { resíduos - Método de ensaio }\end{array}$ \\
\hline & $12988: 1993: 2005$ & $\begin{array}{l}\text { Armazenamento de resíduos sólidos perigosos } \\
\text { - Procedimento }\end{array}$ \\
\hline & $12235: 1992$ & $\begin{array}{l}\text { Resíduo Químico - Informações sobre } \\
\text { segurança, saúde e meio ambiente - Ficha com } \\
\text { Dados de Segurança de Resíduos Químicos } \\
\text { (FDSR) e rotulagem. }\end{array}$ \\
\hline
\end{tabular}


APÊNDICE B

\begin{tabular}{|c|l|l|}
\hline \multirow{2}{*}{ USEXA } & $\begin{array}{l}\text { Página: } \\
\text { DIRETRIZES PARA TREINAMENTO E } \\
\text { CONSCIENTIZAÇÃO }\end{array}$ & $\begin{array}{l}\text { Data da emissão: } \\
\text { Edição: } \\
\text { Data da revisão: }\end{array}$ \\
\hline
\end{tabular}

Para elaboração deste documento procurou-se, seguir a formatação seguida no CTMSP.

\section{OBJETIVO}

Este documento dá diretrizes para os treinamentos que serão aplicados na USEXA, em atendimento à Norma ABNT NBR ISO 14.001: 2004.

\section{CAMPO DE APLICAÇÃO}

Este documento se aplica à USEXA - CEA.

\section{DOCUMENTOS DE REFERÊNCIA}

3.1 NBR ISO 14001: 2004 - Sistemas de Gestão Ambiental - Requisitos com orientações para uso.

3.2 NBR ISO 14004: 2005 - Sistema de Gestão Ambiental - Diretrizes gerais sobre princípios, sistemas e técnicas de apoio.

3.3 NBR ISO 10015: 2001 - Gestão da Qualidade - Diretrizes para treinamento

3.4 Programa Nacional de Educação Ambiental - ProNEA

3.5 Conferência intergovernamental sobre educação ambiental aos países membros

3.6 Lei $n^{\circ}$ 6.938/81 - Dispõe sobre a Política Nacional do Meio Ambiente, seus fins e mecanismos de formulação e aplicação, e dá outras providências

3.7 Resolução CONAMA no 001/96 - Disciplina o Estudo de Impacto Ambiental - EIA e o Relatório de Impacto Ambiental - RIMA. Exigências, conteúdo, elaboração, responsabilidades, audiência pública

3.8 Resolução CONAMA n ${ }^{\circ} 237 / 97$ - Dispõe sobre licenciamento ambiental; competências da União, Estados e Municípios; listagem de atividades sujeitas ao licenciamento; Estudos Ambientais, Estudo de Impacto Ambiental e Relatório de Impacto Ambiental

3.9 Decreto n 4.281/2002 - Política Nacional de Educação Ambiental

3.10 Tratado de Educação Ambiental para Sociedades Sustentáveis e Responsabilidade Global - TEASS

3.11 Objetivos do milênio

3.12 Agenda 21

3.13 Diretrizes modernas de educação e psicologia ambiental na fase de conscientização e treinamento de Sistemas de Gestão Ambiental, 2009

3.14 MATTIOLO, S.R.; BOEMER, V.A.; AQUINO, A.R. Diretrizes modernas de educação ambiental e psicologia ambiental na fase de conscientização e treinamento de Sistemas de Gestão Ambiental. Revista Brasileira de Pesquisa e Desenvolvimento, São Paulo, v. 11, n. 3, p. 79-84, 2009. 
APÊNDICE B

\begin{tabular}{|c|l|l|}
\hline \multirow{2}{*}{ USEXA } & DIRETRIZES PARA TREINAMENTO E & Página: \\
& Data da emissão: \\
& Edição: \\
& Data da revisão: \\
\hline
\end{tabular}

\section{SIGLAS E DEFINIÇÕES}

\subsection{Siglas}

$\begin{array}{ll}\text { ABNT } & \text { Associação Brasileira de Normas Técnicas } \\ \text { CEA } & \text { Centro Experimental Aramar } \\ \text { CTMSP } & \text { Centro Tecnológico da Marinha em São Paulo } \\ \text { DPC } & \text { Diretoria de Portos e Costas da Marinha do Brasil } \\ \text { ISO } & \text { International Organization for Standardization } \\ \text { NBR } & \text { Norma Brasileira } \\ \text { NORTAM } & \text { Norma Técnica Ambiental emitida pela DPC } \\ \text { PAT } & \text { Planilha Anual de Treinamento } \\ \text { PNL } & \text { Programação neurolinguistica } \\ \text { SGA } & \text { Sistema de Gestão Ambiental } \\ \text { TE } & \text { Treinamento específico } \\ \text { TEPA } & \text { Treinamento em educação e psicologia ambiental } \\ \text { TGP } & \text { Treinamento em gestão de pessoas } \\ \text { TSGA } & \text { Treinamento do SGA }\end{array}$

\subsection{Definições}

Treinamento específico - qualificação profissional e a oportunidade de elevar os conhecimentos e de estarem sempre atualizados às inovações dentro das suas atividades. Inclui nesta modalidade os relacionados com energia nuclear, radioproteção, produtos químicos.

Treinamento do SGA - destinados a implantação e operação do Sistema de Gestão Ambiental e deverão suprir as necessidades de todas as fases de implantação: planejamento, implantação, operação e verificação, conforme a Norma ABNT NBR ISO 14.001: 2004 na sua última versão.

Treinamento em educação e psicologia ambiental - permitir que os funcionários aumentem os conhecimentos e assuntos relacionados ao meio 
APÊNDICE B

\begin{tabular}{|c|c|l|}
\hline \multirow{2}{*}{ USEXA } & DIRETRIZES PARA TREINAMENTO E & Página: \\
& Data da emissão: & Edição: \\
& Data da revisão: \\
\hline
\end{tabular}

ambiente, não só do espaço que está inserido a USEXA e o CEA, mas ampliando a visão do colaborador para sua atuação como cidadão do planeta onde vive. Permitirá assim que os funcionários tenham ações adequadas quanto à coleta seletiva, sustentabilidade, uso racional de recursos.

Treinamento em gestão de pessoas - é o conjunto de treinamentos que possibilita orientar o comportamento humano, possibilitando o desenvolvimento de valores que facilitam as mudanças de crenças, hábitos e posturas despertando uma conscientização em todas as áreas de atuação profissional. Esta modalidade de treinamento permitirá a assimilação dos outros treinamentos.

\section{RESPONSABILIDADES}

\subsection{Gerente Ambiental da USEXA}

É de responsabilidade do Gestor Ambiental a elaboração do planejamento anual de treinamentos relativos às atividades da USEXA (PAT), a implantação da gestão ambiental, educação ambiental e gestão de pessoas, e esta última modalidade de treinamento será elaborada juntamente com o Consultor em Gestão de Pessoas, estabelecendo suas necessidades de treinamento para as atividades associadas;

Prever os custos associados com estes treinamentos;

Identificar e fazer escala de funcionários para os respectivos treinamentos;

e Manter a lista de presença arquivada.

\subsection{Gerente da USEXA}

Manter atualizada as Planilhas de Identificação de Aspectos e Impactos Ambientais, para a identificação das necessidades de treinamentos.

Aprovar a Planilha Anual de Treinamento - PAT.

\subsection{Consultor em Gestão de Pessoas}

Profissional contratado por tempo determinado que identificará as necessidades de treinamentos na área de Gestão de Pessoas, conforme a 
APÊNDICE B

\begin{tabular}{|c|c|l|}
\hline \multirow{2}{*}{ USEXA } & DIRETRIZES PARA TREINAMENTO E & Página: \\
& Data da emissão: & Edição: \\
& Data da revisão: \\
\hline
\end{tabular}

necessidades identificadas pelo Gerente da USEXA e Gestor Ambiental da USEXA.

\section{DETALHAMENTO}

\subsection{Planilha Anual de Treinamento - PAT}

A PAT deverá ser elaborada, conforme modelo abaixo:

Planilha Anual de Treinamento - USEXA, 201X

\begin{tabular}{|c|c|c|c|c|}
\hline $\begin{array}{l}\text { Denominação } \\
\text { do treinamento }\end{array}$ & Tipo & Funções ou cargos & $\begin{array}{l}\text { Período de } \\
\text { realização }\end{array}$ & $\begin{array}{l}\text { Realização do } \\
\text { treinamento }\end{array}$ \\
\hline Manutenção & TE & $\begin{array}{l}\text { Operadores da } \\
\text { USEXA }\end{array}$ & $\begin{array}{l}\text { Contratação e } \\
\text { Periodicamente }\end{array}$ & $\begin{array}{l}\text { Empresa contratada } \\
\text { ou colaborador com } \\
\text { experiência e } \\
\text { competência } \\
\text { comprovada }\end{array}$ \\
\hline $\begin{array}{l}\text { Preparação e } \\
\text { resposta a } \\
\text { emergência }\end{array}$ & $\begin{array}{c}\text { TE } \\
\text { TSGA }\end{array}$ & $\begin{array}{l}\text { Colaboradores } \\
\text { identificados pelo } \\
\text { gerente da USEXA }\end{array}$ & Anualmente & $\begin{array}{l}\text { Empresa contratada } \\
\text { ou colaborador com } \\
\text { experiência e } \\
\text { competência } \\
\text { comprovada }\end{array}$ \\
\hline $\begin{array}{l}\text { Interpretação } \\
\text { da ISO } 14001\end{array}$ & TSGA & $\begin{array}{l}\text { Gerente Ambiental } \\
\text { da USEXA e } \\
\text { envolvidos com a } \\
\text { implantação do SGA }\end{array}$ & $\begin{array}{l}\text { Implantação do } \\
\text { SGA e a cada } \\
\text { revisão da norma }\end{array}$ & $\begin{array}{l}\text { Empresa contratada } \\
\text { ou colaborador com } \\
\text { experiência e } \\
\text { competência } \\
\text { comprovada }\end{array}$ \\
\hline $\begin{array}{l}\text { Auditor Interno } \\
\text { da NBR ISO } \\
14001\end{array}$ & TSGA & Auditores internos & $\begin{array}{l}\text { Implantação do } \\
\text { SGA e a cada } \\
\text { revisão da norma }\end{array}$ & $\begin{array}{l}\text { Empresa contratada } \\
\text { ou colaborador com } \\
\text { experiência e } \\
\text { competência } \\
\text { comprovada }\end{array}$ \\
\hline $\begin{array}{l}\text { Legislação } \\
\text { Ambiental }\end{array}$ & TSGA & $\begin{array}{l}\text { Gestor Ambiental da } \\
\text { USEXA e envolvidos } \\
\text { com a implantação } \\
\text { do SGA }\end{array}$ & $\begin{array}{l}\text { Implantação e } \\
\text { Operação do } \\
\text { SGA }\end{array}$ & $\begin{array}{l}\text { Empresa contratada } \\
\text { ou colaborador com } \\
\text { experiência e } \\
\text { competência } \\
\text { comprovada }\end{array}$ \\
\hline $\begin{array}{l}\text { Coleta } \\
\text { Seletiva }\end{array}$ & TEPA & $\begin{array}{l}\text { Todos } \\
\text { colaboradores }\end{array}$ & Contratação & $\begin{array}{l}\text { Gestor Ambiental ou } \\
\text { colaborador com } \\
\text { experiência e } \\
\text { competência } \\
\text { comprovada }\end{array}$ \\
\hline
\end{tabular}


APÊNDICE B

\begin{tabular}{|c|c|l|}
\hline \multirow{2}{*}{ USEXA } & DIRETRIZES PARA TREINAMENTO E & Página: \\
& Data da emissão: \\
& Edição: \\
Data da revisão:
\end{tabular}

\begin{tabular}{|c|c|c|c|c|}
\hline $\begin{array}{l}\text { Denominação } \\
\text { do treinamento }\end{array}$ & $\begin{array}{l}\text { treinam } \\
\text { ento }\end{array}$ & Funções ou cargos & $\begin{array}{l}\text { Período de } \\
\text { realização }\end{array}$ & $\begin{array}{l}\text { Realização do } \\
\text { treinamento }\end{array}$ \\
\hline $\begin{array}{l}\text { Hábitos } \\
\text { sustentáveis }\end{array}$ & TEPA & $\begin{array}{l}\text { Todos } \\
\text { colaboradores }\end{array}$ & $\begin{array}{l}\text { Contratação/Reci } \\
\text { clagens } \\
\text { periódicas }\end{array}$ & $\begin{array}{l}\text { Gestor Ambiental ou } \\
\text { colaborador com } \\
\text { experiência e } \\
\text { competência } \\
\text { comprovada }\end{array}$ \\
\hline $\begin{array}{l}\text { Uso racional } \\
\text { de recursos }\end{array}$ & TEPA & $\begin{array}{l}\text { Todos } \\
\text { colaboradores }\end{array}$ & $\begin{array}{l}\text { Contratação/Reci } \\
\text { clagens } \\
\text { periódicas }\end{array}$ & $\begin{array}{l}\text { Gestor Ambiental ou } \\
\text { colaborador com } \\
\text { experiência e } \\
\text { competência } \\
\text { comprovada }\end{array}$ \\
\hline $\begin{array}{l}\text { Programação } \\
\text { Neuro- } \\
\text { linguistica }\end{array}$ & TGP & $\begin{array}{l}\text { Todos } \\
\text { colaboradores }\end{array}$ & $\begin{array}{l}\text { Contratação/ } \\
\text { Reciclagens } \\
\text { periódicas }\end{array}$ & Empresa contratada \\
\hline Coaching & TGP & $\begin{array}{l}\text { Todos } \\
\text { colaboradores }\end{array}$ & $\begin{array}{l}\text { Contratação/ } \\
\text { Reciclagens } \\
\text { periódicas }\end{array}$ & Empresa contratada \\
\hline $\begin{array}{l}\text { Energia } \\
\text { Nuclear e } \\
\text { Proteção } \\
\text { Radiológica }\end{array}$ & TE & $\begin{array}{l}\text { Todos } \\
\text { colaboradores }\end{array}$ & $\begin{array}{l}\text { Contração/Recicl } \\
\text { agens periódicas }\end{array}$ & $\begin{array}{l}\text { Empresa contratada } \\
\text { ou colaborador com } \\
\text { experiência e } \\
\text { competência } \\
\text { comprovada }\end{array}$ \\
\hline
\end{tabular}

TE - treinamento específico; TSGA - treinamento do SGA; TEPA - treinamento em Educação e Psicologia Ambiental; TGP - treinamento em gestão de pessoas

\subsection{Treinamentos específicos - TE}

Estes treinamentos estão descritos na Instrução Detalhada $n^{\circ}$ ID-XXXXTRE-01.000 - Qualificação de pessoal da USEXA, 201X (a ser elaborada) e serão listados na PAT. Dentro dos treinamentos específicos será dada ênfase aos treinamentos que habilitem os funcionários a agirem de forma preventiva.

\subsection{Treinamentos em SGA - TSGA}

As necessidades dos treinamentos destinados a implantação e operação do Sistema de Gestão Ambiental - SGA, serão identificadas pelo Gerente Ambiental da USEXA, conforme alguns exemplos:

- Identificação de aspectos e impactos ambientais;

- Interpretação da NBR ISO 14001;

- Legislação Ambiental; e 
APÊNDICE B

\begin{tabular}{|c|c|l|}
\hline \multirow{2}{*}{ USEXA } & $\begin{array}{c}\text { Dágina: } \\
\end{array}$ & Data da emissão: \\
& CONSÇão: \\
& Data da revisão: \\
\hline
\end{tabular}

- Auditoria em Sistemas de Gestão Ambiental.

\subsection{Treinamentos em Educação e Psicologia Ambiental}

Estes treinamentos são obrigatórios nos processos de licenciamento ambiental, conforme a Lei $n^{\circ} 6.938$ (BRASIL, 1981), da Resolução CONAMA n 001 (CONAMA, 1986) e Resolução CONAMA nº 237 (CONAMA, 1997), e serão definidos pelo Gestor Ambiental da USEXA, conforme os resultados apresentados no Plano de Monitoramento e Medições (indicadores) e objetivos e metas redefinidas.

A modalidade de treinamento possibilitará o aumento da conscientização e práticas adequadas em relação aos assuntos do meio ambiente, possibilitando a visão do colaborador não só para sua atuação dentro do espaço profissional, como também cidadão do planeta onde vive.

Para desenvolvimento destes treinamentos serão aplicados os conceitos da psicologia ambiental, alinhados com os objetivos propostos no Capítulo $\mathrm{n}^{\circ} 36$ da Agenda 21 (Promoção do ensino, da conscientização e do treinamento); no ProNEA; na Conferência intergovernamental sobre educação ambiental aos países membros; no Decreto no 4.281 (BRASIL, 2002) - Política Nacional de Educação Ambiental; no TEASS; e nos Objetivos do milênio.

Alguns dos treinamentos que poderão ser abordados são:

- Desenvolvimento sustentável; Objetivos do milênio (contribuição da USEXA/CTMSP);

- Ecologia e ecossistemas;

- Coleta Seletiva;

- Consumo racional de recursos (incluindo alimentos);

- Poluição ambiental; e

- Gases do efeito estufa. 
APÊNDICE B

\begin{tabular}{|c|c|l|}
\hline \multirow{2}{*}{ USEXA } & DIRETRIZES PARA TREINAMENTO E & Página: \\
& COATa da emissão: & Edição: \\
& & Data da revisão: \\
\hline
\end{tabular}

\subsection{Treinamentos em Gestão de Pessoas}

Esta modalidade de treinamento permitirá o desenvolvimento e sucesso nas outras modalidades de treinamentos sugeridos neste documento, permitindo o desenvolvimento dos valores pessoais, mudanças de crenças, hábitos e posturas despertando uma conscientização em todas as áreas de atuação profissional.

Existem diversos cursos na área de Gestão de Pessoas, dentre eles sugerimos: PNL e coaching.

\section{REGISTROS}

\begin{tabular}{|c|c|c|c|c|c|c|c|}
\hline $\begin{array}{c}\text { Registro } \\
\text { da } \\
\text { Qualidade }\end{array}$ & $\begin{array}{c}\text { Responsável } \\
\text { pela coleta }\end{array}$ & $\begin{array}{c}\text { Forma de } \\
\text { Indexação }\end{array}$ & $\begin{array}{c}\text { Grau } \\
\text { de } \\
\text { Sigilo }\end{array}$ & $\begin{array}{c}\text { Local do } \\
\text { Arquivo }\end{array}$ & $\begin{array}{c}\text { Forma de } \\
\text { Armazenamento }\end{array}$ & $\begin{array}{c}\text { Tempo } \\
\text { de } \\
\text { Retenção }\end{array}$ & $\begin{array}{c}\text { Disposição } \\
\text { Final }\end{array}$ \\
\hline TRE & $\begin{array}{c}\text { UO } \\
\text { Gerencial }\end{array}$ & Ano & $\begin{array}{c}\text { Ostensi } \\
\text { vo }\end{array}$ & $\begin{array}{c}\text { UO } \\
\text { Gerencial }\end{array}$ & $\begin{array}{c}\text { Digital ou } \\
\text { impresso }\end{array}$ & 5 anos & Destruição \\
\hline
\end{tabular}


APÊNDICE C

\begin{tabular}{|l|l|l|}
\hline USEXA & MANUAL DE GESTÃo AMBIENTAL & $\begin{array}{l}\text { Página: } \\
\text { Data da emissão: } \\
\text { Edição: } \\
\text { Data da revisão: }\end{array}$ \\
\hline
\end{tabular}

Este documento permitirá que os gerentes da USEXA visualizem os itens do SGA que necessitam adequação ou atendimento na íntegra. A itenização utilizada para apresentação deste documento é independente dos capítulos deste trabalho.

\section{Sumário}

1 Apresentação.

2 Sistema de Gestão Ambiental.

2.1 Escopo do Sistema de Gestão Ambiental.

2.2 Siglas.

3 Requisitos do Sistema de Gestão Ambiental.

3.1 Requisitos Gerais.

3.2 Política Ambiental da USEXA.

3.3 Planejamento.

3.3.1 Aspectos e Impactos Ambientais.

3.3.2 Requisitos Legais e Outros

3.3.3 Objetivos, Metas e Programas.

3.4. Implementação e Operação.

3.4.1 Funções, responsabilidades e autoridades.

3.4.2 Competência, Treinamento e Conscientização.

3.4.3 Comunicação.

3.4.4 Documentação

3.4.5 Controle de Documentos

3.4.6 Controle Operacional....

3.4.7 Preparação e Resposta à Emergência

3.5 Verificação

3.5.1 Monitores e Medição

3.5.1.2 Indicadores Ambientais.

3.5.2 Avaliação do Atendimento a Requisitos Legais e Outros.

3.5.3 Não Conformidade, Ação Corretiva e Ação Preventiva.

3.5.4 Controle e Registros.

3.5.5 Auditorias Internas.

3.6 Análise pela Administração

3.7 Melhoria Contínua do SGA

3.8 Histórico de Revisões.

3.9 Anexos. 
APÊNDICE C

\begin{tabular}{|l|l|l|}
\hline USEXA & MANUAL DE GESTÃo AMBIENTAL & $\begin{array}{l}\text { Página: } \\
\text { Data da emissão: } \\
\text { Edição: } \\
\text { Data da revisão: }\end{array}$ \\
\hline
\end{tabular}

\section{Apresentação}

No CTMSP é desenvolvido o Programa Nuclear da Marinha do Brasil que visa à capacitação no domínio dos processos tecnológicos, industriais e operacionais de instalações nucleares aplicáveis à propulsão naval. Em virtude desse grande campo de pesquisa, o CTMSP está dividido em dois sítios, CTMSP - Sede e Centro Experimental Aramar (CEA).

O CTMSP - Sede está localizado na cidade de São Paulo, inserido dentro da Universidade de São Paulo (USP), onde trabalham servidores militares e civis que exercem atividades técnicas de engenharia, pesquisa e desenvolvimento, gerenciamento de projetos e atividades administrativas.

O CEA está localizado em Iperó - SP, a cerca de $120 \mathrm{~km}$ da capital, onde estão sendo implantadas as principais oficinas, usinas, laboratórios e protótipos desenvolvidos pelo CTMSP. Entre eles destacam-se a Unidade de Produção de Hexafluoreto de Urânio (USEXA) que é uma das instalações existentes compreendendo a etapa de conversão do ciclo do combustível nuclear (produção de $\mathrm{HF}_{6}$ para enriquecimento isotópico de urânio).

A instalação completa da USEXA é composta de várias unidades de processo, de utilidades e de apoio, cada uma prevista para realizar uma determinada etapa do processo. Os processos compreendem resumidamente as seguintes sequências de etapas químicas: purificação do concentrado de urânio obtendo-se nitrato de uranilo (NTU); produção de trióxido de urânio $\left(\mathrm{UO}_{3}\right)$, por meio de reações químicas e calcinação; produção de tetrafluoreto de urânio $\left(\mathrm{UF}_{4}\right)$, por meio de reações químicas com fluoreto de hidrogênio e outros elementos em ambiente controlado; produção de flúor $\left(F_{2}\right)$ em células eletrolíticas a partir do fluoreto de hidrogênio (HF); produção e purificação de hexafluoreto de urânio $\left(\mathrm{UF}_{6}\right)$, por meio da reação do $U F_{4}$ com $F_{2}$ em reatores específicos. A previsão da produção é de 40 toneladas de hexafluoreto de urânio por ano, visando atender às necessidades do Programa Nuclear da Marinha e também podendo atender parte das 
APÊNDICE C

\begin{tabular}{|l|l|l|}
\hline USEXA & MANUAL DE GESTÃo AMBIENTAL & $\begin{array}{l}\text { Página: } \\
\text { Data da emissão: } \\
\text { Edição: } \\
\text { Data da revisão: }\end{array}$ \\
\hline
\end{tabular}

necessidades das Indústrias Nucleares do Brasil (INB). A seguir são listadas as instalações da USEXA

O número atribuído a cada edifício/processo que no conjunto formam a USEXA está listado a seguir:

C10.11 - Unidade de Purificação de Nitrato de Uranilo (NTU);

C10.12 - Unidade de Produção de Trióxido de Urânio $\left(\mathrm{UO}_{3}\right)$;

C10.13 - Unidade de Produção de Tetrafluoreto de Urânio (UF $\left.{ }_{4}\right)$;

C10.15 - Unidade de Estocagem de Matéria-Prima;

C10.21 - Unidade de Produção de Hexafluoreto de Urânio (UF ${ }_{6}$ );

C10.22 - Unidade de Produção de Flúor $\left(\mathrm{F}_{2}\right)$;

C10.23 - Unidade de Destilação de Hexafluoreto de Urânio ( $\left(\mathrm{F}_{6}\right)$;

C10.31 - Unidade de Recuperação de Urânio e Tratamento de Rejeitos;

C10.32 - Unidade de Armazenamento Inicial de Rejeitos da USEXA;

C10.41 - Utilidades;

C10.42 - Unidade de Estocagem de Produtos Químicos;

C10.43 - Subestação;

C10.44 - Interligação; e

C10.51 - Apoio.

Abaixo estão descritos de forma resumida, os processos das instalações que compõe a Unidade de Produção de Hexafluoreto de Urânio do Centro Tecnológico da Marinha em São Paulo.

\section{C10.15 - Estocagem de matéria-prima}

Os processos da USEXA iniciam-se na unidade de estocagem de matéria-prima (também chamada de yellow cake) que é responsável pelo recebimento e estocagem do concentrado de urânio. O yellow cake chega por meio de caminhão baú, dentro de tambores metálicos, e é descarregado sobre paletes por empilhadeiras elétricas e armazenado na área de estocagem de matéria-prima. 
APÊNDICE C

\begin{tabular}{|l|l|l|}
\hline USEXA & MANUAL DE GESTÃo AMBIENTAL & $\begin{array}{l}\text { Página: } \\
\text { Data da emissão: } \\
\text { Edição: } \\
\text { Data da revisão: }\end{array}$ \\
\hline
\end{tabular}

\section{C10.11 - Purificação de Nitrato de Uranilo (NTU)}

Essa unidade é responsável pelos processos de dissolução, maturação, filtração e purificação do urânio, partindo do diuranato de amônio para se obter o nitrato de uranilo nuclearmente puro.

Nesta etapa, o yellow cake contido em tambores, após liberação da unidade de estocagem de matéria-prima, abastece um silo de estocagem que alimenta os reatores de dissolução/ maturação, feita com um ataque com ácido nítrico o que resulta em uma solução de nitrato de uranilo. As partículas sólidas insolúveis e a sílica (impureza do concentrado) são separadas da solução por filtração à vácuo. Após a filtração, o licor obtido sofre purificação por extração com solvente em colunas pulsadas. O processo é de fase orgânica contínua, permitindo que o solvente contendo produtos de sua degradação seja continuamente recuperado e reutilizado.

\section{C10.12 - Produção de Trióxido de Urânio $\left(\mathrm{UO}_{3}\right)$}

A solução de nitrato de uranilo purificada e concentrada vinda da unidade de purificação de NTU é enviada para a unidade de produção de $\mathrm{UO}_{3}$.

O nitrato de uranilo é transformado em diuranato de amônio (DUA) mediante reação com amônia gasosa (precipitação). A suspensão de DUA obtida é filtrada à vácuo e a torta gerada, contendo $40 \%$ de sólidos, é seca e calcinada em forno de esteira com convecção, tipo túnel, com fluxo de ar em contracorrente, produzindo o trióxido de urânio semi-hidratado, sob a forma de plaquetas.

$\mathrm{O} \cup \mathrm{O}_{3}$ obtido segue para uma peneira vibratória. Depois do ajuste, o produto é estocado para posterior envio à produção de tetrafluoreto de urânio.

\section{C10.13 - Produção de Tetrafluoreto de Urânio $\left(\mathrm{UF}_{4}\right)$}

Esta unidade tem por finalidade obter tetrafluoreto de urânio a partir do trióxido de urânio semi-hidratado. 
APÊNDICE C

\begin{tabular}{|l|l|l|}
\hline \multirow{2}{*}{ USEXA } & MANUAL DE GESTÃo AMBIENTAL & Página: \\
& & Data da emissão: \\
& Edição: \\
& Data da revisão: \\
\hline
\end{tabular}

Nesta etapa do processo, as reações de redução e de hidrofluoração ocorrem no mesmo equipamento: o reator de leito móvel. Neste reator o material sólido alimentado escoa, em contracorrente, com os gases reagentes introduzidos em pontos diferentes.

O trióxido de urânio semi-hidratado alimentado no reator sofre redução em contato com o fluxo gasoso ascendente contendo $\mathrm{H}_{2}$ proveniente do craqueamento da amônia. $\mathrm{O} \mathrm{UO}_{2}$ formado escoa, para o módulo intermediário onde sofre resfriamento, por troca de calor com o ambiente, pela parede do reator.

$\mathrm{Na}$ próxima etapa $\mathrm{o} \mathrm{UO}_{2}$ é convertido em tetrafluoreto de urânio, por meio da reação com fluoretação.

\section{C10.21 - Produção de Hexafluoreto de Urânio (UF U}

O processo usado para a produção do hexafluoreto de urânio com elevada pureza, parte da síntese direta entre tetrafluoreto de urânio e o flúor elementar, sendo dividido nas seguintes etapas:

- Estocagem e manuseio de material: o $U_{4}$ é recebido por meio de um vaso de transporte. Um moinho de martelos ajusta a granulometria do material recebido para alimentação posterior dos reatores de chama e de pratos, após estocagem em um silo. O circuito de sólidos contempla também o manuseio de cinzas.

- Fluoração primária: nesta etapa o UF 4 , juntamente com as cinzas recicladas no processo, reage com o flúor em excesso no reator de chama, produzindo o UF 6 .

- Fluoração secundária: o UF 4 , juntamente com as cinzas recicladas no processo, reage no reator de pratos com o flúor não convertido no reator de chama e proveniente de um dos cristalizadores primários.

- Cristalização do $\mathrm{UF}_{6}$ : essa etapa contempla a retenção sob a forma sólida, do $\mathrm{UF}_{6}$ produzido. 
APÊNDICE C

\begin{tabular}{|l|l|l|}
\hline USEXA & MANUAL DE GESTÃo AMBIENTAL & $\begin{array}{l}\text { Página: } \\
\text { Data da emissão: } \\
\text { Edição: } \\
\text { Data da revisão: }\end{array}$ \\
\hline
\end{tabular}

\section{C10.23 - Destilação de Hexafluoreto de Urânio $\left(\mathrm{UF}_{6}\right)$}

Sua finalidade é a obtenção do hexafluoreto de urânio puro com qualidade nuclear, com base em material proveniente da unidade de produção de $\mathrm{UF}_{6} \mathrm{e}$, eventualmente, de $\mathrm{UF}_{6}$ reciclado no final do processo.

O sistema de destilação é composto basicamente da Coluna de Destilação; do Condensador da Fração e do Refervedor da Fração Pesada. O condensador tem por finalidade condensar parcialmente a corrente de vapor que sai pela coluna, ao passo que o refervedor tem a função de vaporizar a corrente líquida com componentes pesados provenientes do fundo da coluna, ambas as correntes retornam à coluna. O hexafluoreto de urânio é retirado lateralmente da coluna de destilação no estado de vapor saturado para eliminação do HF não reagido. O $\mathrm{UF}_{6}$ puro é condensado, escoado para um vaso de estocagem e depois transferido para cilindros de estocagem, dotados de sistema de resfriamento.

\section{C10.22 - Produção de Flúor $\left(F_{2}\right)$}

Essa unidade produz o flúor usado no processo por eletrólise de sal fundido em cubas eletroquímica de temperatura média. $\mathrm{O}$ processo é dividido em preparo e transferência do eletrólito, condicionamento, eletrólise (produção de flúor).

\section{C10.31 - Recuperação de Urânio e Tratamento de Efluentes e Rejeitos}

Unidade responsável pela recuperação de urânio, tratamento, monitoração e controle de todos os rejeitos/efluentes líquidos e sólidos de processo provenientes da USEXA. Independente disso, cada unidade é responsável pelo tratamento dos gases da exaustão do processo. Após o tratamento, os gases limpos são lançados na atmosfera, ou no ponto mais alto do respectivo prédio.

Os tambores vazios de concentrado de urânio são lavados com água. A água de lavagem dos tambores, contendo DUA, é enviada para tratamento. Os rejeitos sólidos e líquidos das diversas unidades são enviados para tratamento e eventual recuperação de urânio. 
APÊNDICE C

\begin{tabular}{|l|l|l|}
\hline USEXA & MANUAL DE GESTÃo AMBIENTAL & $\begin{array}{l}\text { Página: } \\
\text { Data da emissão: } \\
\text { Edição: } \\
\text { Data da revisão: }\end{array}$ \\
\hline
\end{tabular}

\section{C10.32 - Armazenamento inicial de Rejeitos da USEXA}

Os rejeitos sólidos gerados na USEXA serão armazenados nesta unidade, cuja localização e projeto ainda estão sendo definidos.

\section{C10.41 - Utilidades}

As funções desta unidade são as de preparar, estocar e fornecer adequadamente as utilidades necessárias à operação da USEXA. Abrange os Sistemas de: Água desmineralizada; Água de resfriamento; Ar comprimido (ar de processo, industrial e de instrumentos); Água tratada, água potável e de efluentes; e Geração de Vapor.

\section{C10.42 - Estocagem de Produtos Químicos}

Unidade responsável pelo recebimento, estocagem e transferência dos diversos produtos químicos consumidos nas unidades da USEXA e está dividida em duas subunidades: estocagem de produtos químicos embalados e estocagem de produtos químicos líquidos a granel.

\section{C10.43 - Subestação}

Estação secundária que transformará e distribuirá a corrente elétrica.

\section{C10.51 - Apoio}

Salas de projetos e administrativas; sala de reunião; sanitários e copa.

\section{Sistema de Gestão Ambiental}

O Sistema de Gestão Ambiental da USEXA abrange o conjunto de processos e atividades relacionadas à fase de conversão do ciclo do combustível nuclear, em instalação localizada no Centro Experimental ARAMAR (CEA). 
APÊNDICE C

\begin{tabular}{|l|l|l|}
\hline USEXA & MANUAL DE GESTÃo AMBIENTAL & $\begin{array}{l}\text { Página: } \\
\text { Data da emissão: } \\
\text { Edição: } \\
\text { Data da revisão: }\end{array}$ \\
\hline
\end{tabular}

\subsection{Escopo do Sistema de Gestão Ambiental}

A USEXA mantem seu sistema de gestão ambiental visando melhorar continuamente seus processos e atender os requisitos legais, segurança e saúde dos trabalhadores.

\subsection{Siglas}

ABNT - Associação Brasileira de Normas Técnicas

ACP - Ação corretiva

ADM - Responsabilidade da administração

AUD - Auditoria

CEA - Centro Experimental ARAMAR

SGA - Sistema de Gestão Ambiental

NORTAM - Norma Técnica Ambiental da Marinha

DPC - Diretoria de Portos e Costas

USEXA - Unidade de Produção de Hexafluoreto de Urânio

CNEN - Comissão Nacional de Energia Nuclear

CONAMA - Conselho Nacional do Meio Ambiente

CPR - Controle de Processo

CTMSP - Centro Tecnológico da Marinha em São Paulo

DBO - Demanda bioquímica de oxigênio

DGMM - Diretoria Geral de Material da Marinha

DQO - Demanda química de oxigênio

DUA - Diuranato de Amônio

GEE - Gases do Efeito Estufa

ID - Instrução Detalhada

ISO - International Organization for Standardization

NBR - Norma Brasileira

NCF - Não conformidade

NTU - Nitrato de Uranilo 
APÊNDICE C

\begin{tabular}{|l|l|l|}
\hline USEXA & MANUAL DE GESTÃo AMBIENTAL & $\begin{array}{l}\text { Página: } \\
\text { Data da emissão: } \\
\text { Edição: } \\
\text { Data da revisão: }\end{array}$ \\
\hline
\end{tabular}

PAT - Plano Anual de Treinamento

PE - Plano de Emergência (nomenclatura antiga)

PEL - Plano de Emergência Local

PG - Programa

PGA - Plano de Gestão Ambiental

$\mathrm{pH}$ - potencial hidrogêniônico

PMA - Plano de Monitoramento Ambiental

PR - Procedimento

PRE - Preparação e respostas a emergência

REG - Registros

TER - Treinamento

\section{Requisitos do Sistema de Gestão Ambiental}

\subsection{Requisitos Gerais}

O Sistema de Gestão Ambiental da USEXA está estabelecido de acordo com os requisitos das normas ABNT NBR ISO 14.001, 14.004 e NORTAM $n^{\circ} 02$, para assegurar que as atividades realizadas estejam em conformidade com a Política Ambiental da USEXA.

Os aspectos e impactos ambientais significativos associados às atividades desenvolvidas na USEXA, constituem-se na base do Sistema de Gestão Ambiental. Sobre estes estão estabelecidos procedimentos, instruções detalhadas, controles operacionais pertinentes, monitoramentos ambientais, objetivos, metas e programas de ações ambientais, entre outras práticas de gestão.

Os riscos ambientais relacionados às atividades são avaliados, conhecidos e registrados. Ações de prevenção são adotadas para prevenir as ocorrências de tais situações. Planos de Ação de Emergência estão estabelecidos para controlar os aspectos e impactos ambientais provocados por eventuais acidentes. 
APÊNDICE C

\begin{tabular}{|l|l|l|}
\hline USEXA & MANUAL DE GESTÃo AMBIENTAL & $\begin{array}{l}\text { Página: } \\
\text { Data da emissão: } \\
\text { Edição: } \\
\text { Data da revisão: }\end{array}$ \\
\hline
\end{tabular}

Periodicamente, são realizadas avaliações do SGA para identificar o nível de conformidade das práticas empregadas com os requisitos do Sistema de Gestão Ambiental e da Política Ambiental da USEXA, incluindo o atendimento à legislação ambiental e outros requisitos aplicáveis, definindo, sempre que necessário, ações apropriadas à melhoria do desempenho ambiental da USEXA.

\subsection{Política Ambiental da USEXA}

Produzir hexafluoreto de urânio para suprir as necessidades do Centro Tecnológico da Marinha em São Paulo elevando o nível de independência tecnológica do Brasil. Para tal assumimos compromisso com o cumprimento das legislações vigentes e melhoras constantes na área de segurança, saúde e proteção do meio ambiente, bem como o estabelecimento de procedimentos para a prevenção da poluição e atendimento aos objetivos e metas ambientais.

\subsubsection{Aspectos e Impactos Ambientais}

Os aspectos e respectivos impactos ambientais reais e potenciais são identificados e caracterizados para situações normais e eventuais.

\begin{tabular}{|c|c|}
\hline Documento aplicável & Descrição \\
\hline PR-CTMSP-SGA-01_00 & $\begin{array}{c}\text { Identificação de aspectos e impactos } \\
\text { ambientais, 2003 }\end{array}$ \\
\hline
\end{tabular}

Os impactos ambientais são avaliados quanto à sua significância, considerandose sua severidade, frequência, legislação aplicável e outros requisitos.

\begin{tabular}{|c|c|}
\hline Documento aplicável & Descrição \\
\hline PR-CTMSP-SGA-02_00 & $\begin{array}{c}\text { Avaliação dos impactos ambientais, 2003 } \\
\text { (conforme Mattiolo et al (2011) }\end{array}$ \\
\hline
\end{tabular}


APÊNDICE C

\begin{tabular}{|l|l|l|}
\hline USEXA & MANUAL DE GESTÃo AMBIENTAL & $\begin{array}{l}\text { Página: } \\
\text { Data da emissão: } \\
\text { Edição: } \\
\text { Data da revisão: }\end{array}$ \\
\hline
\end{tabular}

Os impactos ambientais significativos são considerados na definição dos objetivos, metas e programas.

\subsubsection{Requisitos Legais e Outros}

A USEXA mantém sistemática para a identificação e acesso à legislação ambiental aplicável e outros requisitos relacionados às suas atividades, avalia sua aplicabilidade, definindo ações e responsáveis para atendimento do novo requisito.

A USEXA contrata serviço especializado, que fornece, mensalmente, um banco de dados contendo todos os diplomas ambientais em nível federal, estadual e do município de Iperó - São Paulo, além da cópia na íntegra do texto.

\begin{tabular}{|c|c|}
\hline Documento aplicável & Descrição \\
\hline PR-CTMSP-SGA-03_00 & Identificação de requisitos legais de 2003 \\
\hline
\end{tabular}

\subsubsection{Objetivos, Metas e Programas}

São estabelecidos e documentados no PGA - Plano de Gestão Ambiental, os objetivos, metas e programas de gestão ambiental da USEXA para atendimento à Política Ambiental. O PGA também é instrumento para execução das metas estabelecidas.

Os objetivos, metas e programas são revisados na ocorrência de novas unidades, requisitos legais e outros requisitos, aspectos ambientais significativos, opções tecnológicas, requisitos financeiros, operacionais e comerciais, programas de ações ambientais e a visão das partes interessadas.

Anualmente os objetivos e metas por meio de reuniões de análise do Sistema de Gestão Ambiental, com a Alta Administração. Abaixo são listados os principais objetivos e programas do SGA da USEXA: 
APÊNDICE C

\begin{tabular}{|l|l|l|}
\hline USEXA & MANUAL DE GESTÃo AMBIENTAL & $\begin{array}{l}\text { Página: } \\
\text { Data da emissão: } \\
\text { Edição: } \\
\text { Data da revisão: }\end{array}$ \\
\hline
\end{tabular}

\begin{tabular}{l|l}
\hline \multicolumn{1}{c|}{ Objetivos } & \multicolumn{1}{c}{ Metas } \\
\hline 1. Prevenir incêndios & 1. Treinar os operadores em combate a incêndio, até \\
& 201X; 2. Treinar os funcionários administrativos em \\
& combate a incêndio, até 201X; 3. Implantar \\
& Programa de Prevenção a Incêndios, até 201X \\
\hline 2. Prevenir explosões & $\begin{array}{l}\text { 1. Elaborar Programa de Prevenção e Emergência a } \\
\text { Explosões até 201X; 2. Implantar o Programa até } \\
\end{array}$ \\
& $\begin{array}{l}\text { 201X; 3. Treinar os operadores em casos de } \\
\text { explosões, até 201X }\end{array}$ \\
\hline
\end{tabular}

3. Reduzir riscos de 1 . Treinar técnicos para inspeções periódicas, até vazamento de substâncias químicas 201X; 2. Adquirir mantas absorvedoras, para cada unidade, até 201X; 3. Treinar os funcionários em casos de vazamentos de substâncias químicas; 4. Elaborar o Plano de Emergência Ambiental não radioativa

4. Treinar os funcionários 1. Treinar os operadores em casos de vazamentos, em caso de emergência até 201X; 2. Implantar programa de prevenção a com HF

5. Reduzir a emissão de 1. Caracterizar e quantificar todas as emissões efluentes líquidos e líquidas até 201X; 2. Caracterizar e quantificar todas gasosos $\quad$ as emissões gasosas até 201X; 3. Estudar processos alternativos de tratamento de efluentes líquidos até 201X; 4. Estudar processos alternativos de tratamento de efluentes gasosos até 201X e substituição do diesel por biodiesel; 5 . Elaboração do PEI - Plano de Emergência Individual; 6. Operação do SITEA até $201 \mathrm{X}$

6. Reduzir o consumo de água e energia elétrica

1. Quantificar o consumo de água e energia elétrica dos setores administrativos e industriais até 201X; 2. Promover conscientização sobre economia de água e energia, até 201X; 3. Estudar os processos industriais para reuso da água até $201 \mathrm{X}$

7. Implantar coleta 1 . Caracterizar e quantificar os resíduos sólidos e os seletiva e gerenciamento recicláveis, até 201X; 2. Treinar os funcionários para de resíduos sólidos $\quad$ a coleta seletiva até 201X

3. Elaborar Programa de Coleta Seletiva que inclui os resíduos perigosos, inclusive as embalagens de produtos químicos até 201X

8. Qualificar e treinar os 1 . Elaborar um Programa de Treinamento e funcionários em Conscientização com diretrizes modernas de gestão desenvolvimento pessoal pessoal, educação e psicologia ambiental e educação ambiental 
APÊNDICE C

\begin{tabular}{|l|l|l|}
\hline \multirow{2}{*}{ USEXA } & MANUAL DE GESTÃO AMBIENTAL & Página: \\
& & Data da emissão: \\
& Edição: \\
& Data da revisão: \\
\hline
\end{tabular}

\subsection{Implementação e Operação}

\subsubsection{Funções, responsabilidades e autoridades}

A organização e atividades do CTMSP estão estruturadas no Regulamento aprovado pela Portaria No 214/DGMM de 19 de agosto de 2008. No Capítulo III (Da Organização), o Artigo $5^{\circ}$ traz que: "O CTMSP é subordinado militar e administrativamente à Diretoria-Geral do Material da Marinha". A USEXA está subordinada à Superintendência de Operação (Departamento de Operação da USEXA) do CTMSP, que responde diretamente ao Sr. Diretor, conforme FIG. 2 abaixo.

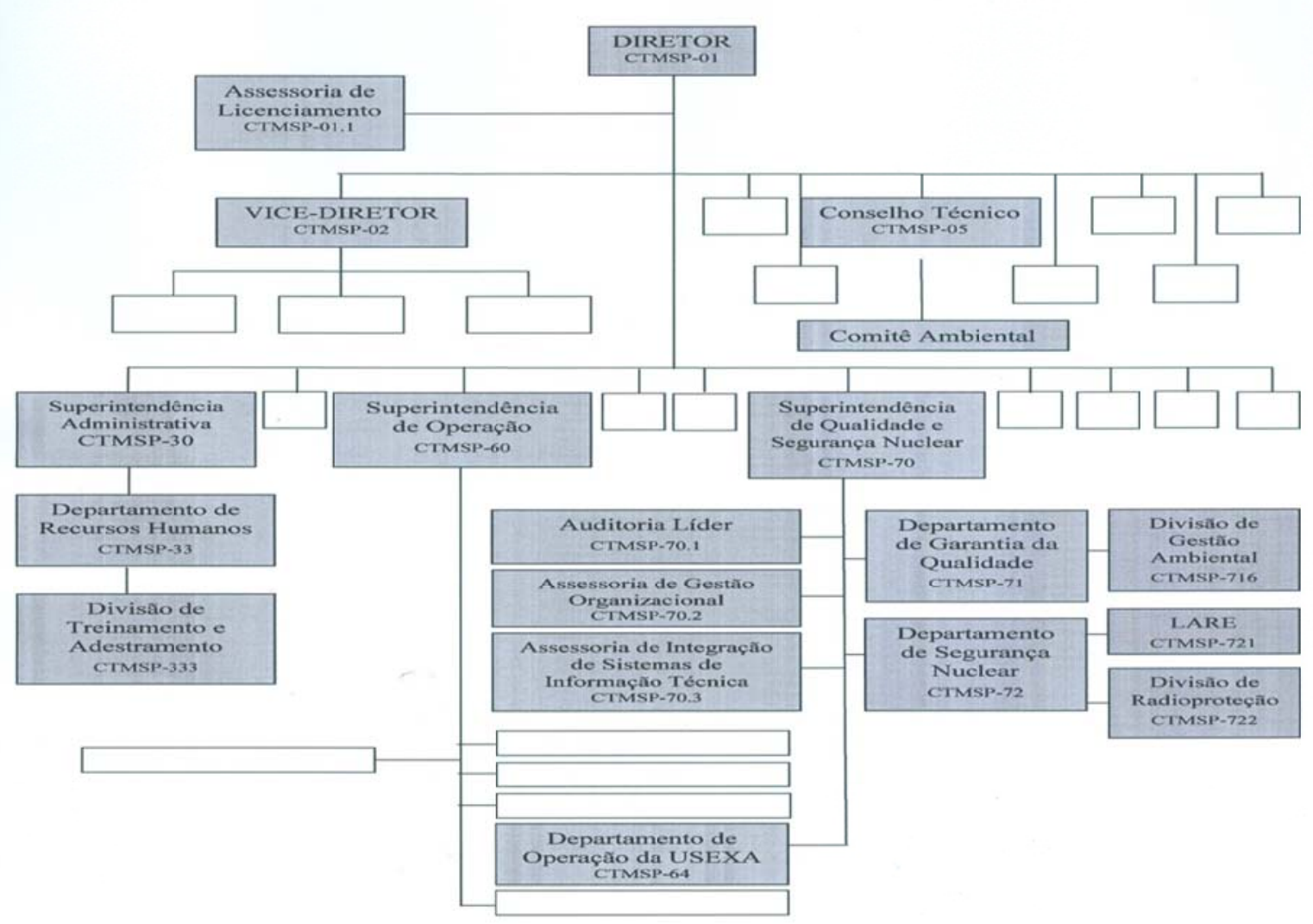

\subsubsection{Competência, Treinamento e Conscientização}

A USEXA mantém atualizado o Resumo de Competência, identificando as necessidades de treinamentos específicos para desenvolvimento da função. E 
APÊNDICE C

\begin{tabular}{|l|l|l|}
\hline USEXA & MANUAL DE GESTÃo AMBIENTAL & $\begin{array}{l}\text { Página: } \\
\text { Data da emissão: } \\
\text { Edição: } \\
\text { Data da revisão: }\end{array}$ \\
\hline
\end{tabular}

sempre que houver mudanças tecnológicas e/ou organizacionais, este resumo deverá ser atualizado.

\begin{tabular}{|c|c|}
\hline Documento aplicável & Descrição \\
\hline ID-A2410-TRE-01.001 & $\begin{array}{c}\text { Qualificação de pessoal do Departamento de } \\
\text { Garantia da Qualidade, 2011(deverá ser } \\
\text { adequado a USEXA) }\end{array}$ \\
\hline PR n n CTMSP-TRE-01 & $\begin{array}{c}\text { Treinamento de pessoal, 2001 (adequação do } \\
\text { SGA) }\end{array}$ \\
\hline
\end{tabular}

A USEXA também estabelece o PAT - Plano Anual de Treinamento, identificando os treinamentos específicos, os necessários à implantação e operação do SGA (para as atividades que podem afetar o desempenho ambiental), os de educação e psicologia ambiental e os de gestão pessoal.

Documento aplicável

\section{Descrição}

Treinamento e Conscientização (item 3.1.2.2.1)

São desenvolvidos programas de conscientização e sensibilização dos colaboradores, para que os mesmos estejam conscientes sobre:

- a importância da conformidade com a política ambiental, procedimentos e requisitos do Sistema de Gestão Ambiental;

- os impactos ambientais significativos, reais ou potenciais, das atividades;

- dos benefícios ao meio ambiente resultantes da melhoria do desempenho pessoal;

- suas funções e responsabilidade em atingir a conformidade com os requisitos do sistema de gestão ambiental; e

- as potenciais consequências da inobservância de procedimentos operacionais específicos. 
APÊNDICE C

\begin{tabular}{|l|l|l|}
\hline USEXA & MANUAL DE GESTÃo AMBIENTAL & $\begin{array}{l}\text { Página: } \\
\text { Data da emissão: } \\
\text { Edição: } \\
\text { Data da revisão: }\end{array}$ \\
\hline
\end{tabular}

Os registros de treinamento, qualificação e experiência são mantidos, de acordo com procedimentos específicos sob a responsabilidade da área do SGA da USEXA.

\begin{tabular}{|c|c|}
\hline Documento aplicável & Descrição \\
\hline (a ser elaborado) & Registros de conscientização e treinamentos \\
\hline
\end{tabular}

\subsubsection{Comunicação}

A USEXA possui a Politica Ambiental fixada em quadros.

A USEXA pode contar com o BS - Boletim Semanal para divulgar informações importantes às partes interessadas. No BS também é apresento os temas relacionados às questões ambientais para conscientizar os colaboradores. $\mathrm{Na}$ intranet existe área destinada ao "meio ambiente" com canal de relacionamento com a Divisão de Gestão Ambiental do CTMSP.

Na página do CTMSP (http://www.mar.mil.br/ctmsp/fale conosco.html) existe um canal ("FALE CONOSCO" para comunicação com a sociedade e a comunidade no entorno. O CTMSP e a USEXA mantém o recebimento, documentação e resposta à comunicação pertinente oriundas das partes interessadas externas.

\begin{tabular}{|c|c|}
\hline Documento aplicável & Descrição \\
\hline (a ser elaborado) & $\begin{array}{c}\text { Procedımento de comunicaçäo interna e } \\
\text { externa }\end{array}$ \\
\hline
\end{tabular}

\subsubsection{Documentação}

A USEXA mantém seu Sistema de Gestão Ambiental documentado, conforme a seguinte estrutura:

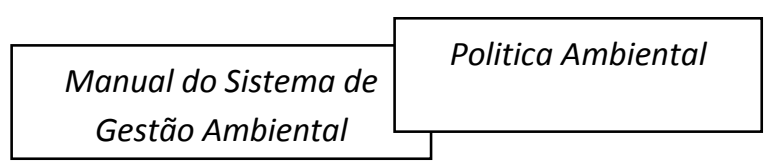

Procedimentos Sistêmicos

Instruções Detalhadas, Procedimento

Operacional, PMA, PEL, etc. 
APÊNDICE C

\begin{tabular}{|l|l|l|}
\hline \multirow{2}{*}{ USEXA } & MANUAL DE GESTÃo AMBIENTAL & Página: \\
& & Data da emissão: \\
& Edição: \\
& Data da revisão: \\
\hline
\end{tabular}

O Manual do Sistema de Gestão Ambiental descreve os principais elementos do Sistema de Gestão Ambiental.

Os Procedimentos Sistêmicos estabelecem as responsabilidades e as práticas adotadas para a Gestão Ambiental do CTMSP e da USEXA.

As Instruções Detalhadas, Planos, Programas, Procedimento Operacional, estabelecem as rotinas da gestão ambiental e as rotinas específicas da USEXA.

Os Registros evidenciam a implementação e manutenção do Sistema de Gestão Ambiental e fornecem informações para análise de desempenho e o planejamento de novos ciclos de melhoria contínua.

\subsubsection{Controle de Documentos}

Estão estabelecidos e mantidos procedimentos para controle de documentos, para assegurar que todos os documentos relativos ao Sistema de Gestão Ambiental, sejam legíveis, datados, inclusive com datas de revisão, facilmente identificável quanto à aplicação, distribuição, aprovação e revisão, mantida de forma organizada e retida por períodos definidos de tempo.

\begin{tabular}{|c|c|}
\hline Documento aplicável & Descrição \\
\hline PR-CTMSP-REG-01 & $\begin{array}{c}\text { Controle de registros da qualidade e gestão } \\
\text { ambiental, 2008 }\end{array}$ \\
\hline
\end{tabular}

\subsubsection{Controle Operacional}

De acordo com os impactos ambientais significativos são estabelecidos e mantidos procedimentos que asseguram:

- A Política Ambiental, os objetivos, metas e programas, além dos requisitos para atendimento do sistema de gestão ambiental;

- Critérios operacionais estejam claramente definidos; e 
APÊNDICE C

\begin{tabular}{|l|l|l|}
\hline USEXA & MANUAL DE GESTÃo AMBIENTAL & $\begin{array}{l}\text { Página: } \\
\text { Data da emissão: } \\
\text { Edição: } \\
\text { Data da revisão: }\end{array}$ \\
\hline
\end{tabular}

- As manutenções em todos os equipamentos cuja falha ou defeito, pode causar impactos ambientais significativos, incluindo equipamentos e sistemas de controle de poluição.

\subsubsection{Preparação e Resposta à Emergência}

O CTMSP possui diretrizes em caso de emergência em instalações nucleares e convencionais, tanto para a Sede como para o CEA, estabelecidos nos Plano de Emergência Local - PEL, com exercícios de ativação periódicos.

As condutas em situações de emergências ambientais na USEXA são estabelecidas em procedimentos específicos, elaborados a partir da identificação e avaliação de aspectos e impactos. Os recursos necessários de combate às situações de emergência são adequadamente mantidos, de forma a minimizar os riscos de falha.

\begin{tabular}{|c|c|}
\hline Documento aplicável & Descrição \\
\hline ID n ${ }^{\circ}$ C1099-PRE-01.001 & Combate a incèndios na USEXA, 2011 \\
\hline ID nº C1099-PRE-01.002 & $\begin{array}{c}\text { Combate a vazamentos de gases perigosos } \\
\text { na USEXA, } 2011\end{array}$ \\
\hline ID n C1099-PRE-01.003 & $\begin{array}{c}\text { Combate a vazamentos de líquidos contendo } \\
\text { materiais radioativos e/ou perigosos na } \\
\text { USEXA, 2011 }\end{array}$ \\
\hline (a ser elaborado) & $\begin{array}{l}\text { Plano de emergência ambiental da USEXA } \\
\text { (Ser elaborado) }\end{array}$ \\
\hline (a ser elaborado) & $\begin{array}{c}\text { Plano de emergência individual - óleo (a ser } \\
\text { elaborado) }\end{array}$ \\
\hline
\end{tabular}

\subsection{Verificação}

\subsubsection{Monitoramento e Medição}

A Unidade C10.31 - Recuperação de Urânio e Tratamento de Efluentes e Rejeitos monitora e trata todos os efluentes e rejeitos gerados em todas as unidades. 
APÊNDICE C

\begin{tabular}{|l|l|l|}
\hline USEXA & MANUAL DE GESTÃo AMBIENTAL & $\begin{array}{l}\text { Página: } \\
\text { Data da emissão: } \\
\text { Edição: } \\
\text { Data da revisão: }\end{array}$ \\
\hline
\end{tabular}

Além disso, o LARE - Laboratório Radioecológico do CTMSP desenvolve o Programa de Monitoração Ambiental - PMA aprovado pela CNEN, que promove coletas em 56 pontos de amostragem distribuídos num raio de $10 \mathrm{~km}$ a partir do CEA. São coletadas amostras de água do rio, água de chuva e de poços, particulados do ar, solo, peixes, produtos agrícolas, leite, sedimentos do rio e é medida a radiação direta. Esse Programa se compõe, na realidade, de dois subprogramas:

- Programa de Monitoração Radiológica, onde é avaliada a possibilidade de contaminação radiológica do individuo do público e são feitas as seguintes análises nas diversas amostras ambientais: determinação de emissores alfa, beta e gama; dosimetria termoluminescente e urânio por meio da fluorimetria; e - Programa de Monitoração não Radiológica, consistindo de análise da qualidade das águas de mananciais, precipitação pluviométrica e água subterrânea. Nessas amostras são realizadas determinação de metais tóxicos, sódio, potássio, pH, oxigênio dissolvido, DBO, DQO, amônia, fosfato, nitrato e outros parâmetros que constam da Resolução CONAMA n $357 / 2005$, onde são estabelecidos padrões de qualidade dos recursos hídricos.

Os registros de monitoramento e medições são mantidos e permanecem retidos, por período especificado, para que seja efetuado o acompanhamento do desempenho ambiental, evidenciada a implantação dos controles operacionais pertinentes e demonstrar a conformidade com a Política, objetivos, metas e programas do SGA.

Procedimentos específicos asseguram que equipamentos de monitoramento são adequadamente escolhidos, calibrados e mantidos, ou quando realizado por terceiros, recebem gerenciamento adequado. 
APÊNDICE C

\begin{tabular}{|l|l|l|}
\hline USEXA & MANUAL DE GESTÃo AMBIENTAL & $\begin{array}{l}\text { Página: } \\
\text { Data da emissão: } \\
\text { Edição: } \\
\text { Data da revisão: }\end{array}$ \\
\hline
\end{tabular}

\begin{tabular}{|c|c|}
\hline Documento aplicável & Descrição \\
\hline $\begin{array}{l}\text { Progr. } n^{\circ} \text { A18.02-0200-PG- } \\
0003\end{array}$ & $\begin{array}{l}\text { Programa de monitoração ambiental do CEA, } \\
2007\end{array}$ \\
\hline ID n A1801-CPR-01.025 & $\begin{array}{l}\text { Monitoração rotineira no galpão de armazenagem } \\
\text { de DUA, } 2008\end{array}$ \\
\hline ID nº A1801-CPR-01.033 & $\begin{array}{l}\text { Monitoração e descarte de efluentes provenientes } \\
\text { da limpeza interna de cilindros de } \mathrm{UF}_{6}, 2010\end{array}$ \\
\hline $\begin{array}{l}\text { Plano n A18.01-0400-PL- } \\
0001\end{array}$ & $\begin{array}{l}\text { Plano de proteção radiológica do CEA - } \\
\text { ocupacional do CTMSP, } 2009\end{array}$ \\
\hline (a ser elaborado) & Plano de monitoramento e medições (indicadores) \\
\hline
\end{tabular}

\subsubsection{Indicadores ambientais}

O CTMSP utiliza indicadores ambientais para monitorar o desempenho ambiental, a fim de monitorar os objetivos e metas do PGA, analisando criticamente se as ações tomadas pelo SGA do CTMSP estão apresentando resultados satisfatórios, ou ainda, se existe algum aspecto ambiental crítico. Abaixo estão relacionados os principais indicadores ambientais monitorados pelo CTMSP, que serão também quantificados pela USEXA:

- Consumo de água

\begin{tabular}{ll}
\hline & $\begin{array}{l}\text { Resíduos domésticos não } \\
\text { reciclados }\end{array}$ \\
\cline { 2 - 2 } & Resíduos recicláveis \\
\cline { 2 - 2 } & Resíduos laboratoriais estocados \\
\hline - & Energia \\
\hline Replantio \\
\hline Investimentos de GEE \\
\hline Pano de Ação \\
\hline
\end{tabular}


APÊNDICE C

\begin{tabular}{|l|l|l|}
\hline \multirow{2}{*}{ USEXA } & MANUAL DE GESTÃo AMBIENTAL & Página: \\
& & Data da emissão: \\
& Edição: \\
& Data da revisão: \\
\hline
\end{tabular}

\subsubsection{Avaliação do atendimento a requisitos legais e outros}

Periodicamente são efetuadas avaliações do atendimento à legislação e ao estabelecido neste Manual do Sistema de Gestão Ambiental, aplicáveis a cada unidade da USEXA, independente das auditorias.

A verificação do cumprimento dos requisitos legais e outros requisitos subscritos será executada pelos responsáveis pelo SGA da USEXA, onde se fizer necessário, são estabelecidas ações corretivas ou preventivas cabíveis.

A USEXA mantem registros dos resultados das avaliações periódicas dos requisitos legais e outros.

\begin{tabular}{|c|c|}
\hline Documento aplicável & Descrição \\
\hline PR-CTMSP-SGA-03_00 & Identificação de requisitos legais, 2003 \\
\hline
\end{tabular}

\subsubsection{Não Conformidade, Ação Corretiva e Ação Preventiva}

Estão estabelecidos procedimentos documentados para a identificação de não conformidades, definindo responsabilidade e autoridade para adoção de ações mitigadoras de quaisquer impactos ambientais significativos e para a tomada de ações corretivas e preventivas.

\begin{tabular}{|c|c|}
\hline $\begin{array}{c}\text { Documentos } \\
\text { aplicáveis }\end{array}$ & Descrição \\
\hline PR-CTMSP-NCF-01 & Controle de não conformidades, 2012 \\
\hline PR-CTMSP-SGA-XX_ & $\begin{array}{c}\text { Controle de não conformidades ambientais, 201x } \\
\text { (em aprovação) }\end{array}$ \\
\hline PR-CTMSP-ACP-01 & Ação corretiva e ação preventiva, 2008. \\
\hline
\end{tabular}

\subsubsection{Controle e Registros}

São mantidos de forma clara e legível os registros de treinamento, monitoramento e medição, auditorias, análises pela Alta Administração e outros pertinentes, para demonstrar conformidades com os requisitos do Sistema de Gestão Ambiental. 
APÊNDICE C

\begin{tabular}{|l|l|l|}
\hline USEXA & MANUAL DE GESTÃo AMBIENTAL & $\begin{array}{l}\text { Página: } \\
\text { Data da emissão: } \\
\text { Edição: } \\
\text { Data da revisão: }\end{array}$ \\
\hline
\end{tabular}

Tais registros são identificados, mantidos e retidos, por período definido de tempo, de modo que se possam rastrear as atividades envolvidas.

Os registros ambientais são arquivados e mantidos de forma organizada pela USEXA conforme definido em procedimento específico do SGA, estando protegidos contra perdas e avarias e prontamente disponíveis quando solicitados.

\begin{tabular}{|c|c|}
\hline Documento aplicável & Descrição \\
\hline PR-CTMSP-REG-01 & $\begin{array}{c}\text { Controle de registros da qualidade e gestão } \\
\text { ambiental, 2008. }\end{array}$ \\
\hline
\end{tabular}

\subsubsection{Auditorias Internas}

Auditorias do SGA são realizadas, quando solicitadas ao Auditor Líder conforme procedimento específico.

As auditorias ambientais são realizadas para:

- Verificar se as disposições planejadas estão em conformidade;

- Se estiver efetivamente implementado e operando; e

- Fornecer a Alta Administração, informações sobre a implantação e manutenção do SGA.

As auditorias são conduzidas por profissionais devidamente qualificados, conforme procedimento específico, que sejam independentes da função auditada, de modo a assegurar imparcialidade e objetividade de julgamento.

\begin{tabular}{|c|c|}
\hline $\begin{array}{c}\text { Documento } \\
\text { aplicável }\end{array}$ & Descrição \\
\hline PR-CTMSP-AUD-01 & $\begin{array}{c}\text { Execução de auditorias internas da qualidade, } \\
\text { 2001(adequação para o SGA) }\end{array}$ \\
\hline
\end{tabular}


APÊNDICE C

\begin{tabular}{|l|l|l|}
\hline USEXA & MANUAL DE GESTÃo AMBIENTAL & $\begin{array}{l}\text { Página: } \\
\text { Data da emissão: } \\
\text { Edição: } \\
\text { Data da revisão: }\end{array}$ \\
\hline
\end{tabular}

\subsection{Análise pela Administração}

São conduzidas anualmente, as reuniões de análise pela Alta Administração do Sistema de Gestão Ambiental, para assegurar sua continuada adequação, pertinência e eficácia.

A análise deve incluir a avaliação de oportunidades de melhorias e a necessidade de alteração no SGA, inclusive na política ambiental da USEXA e dos objetivos e metas ambientais.

Os resultados das análises são registrados de modo conveniente, para assegurar que as ações necessárias sejam implementadas.

\begin{tabular}{|c|c|}
\hline Documento aplicável & Descrição \\
\hline PR-CTMSP-ADM-01 & $\begin{array}{c}\text { Análise crítica do Sistema da Qualidade, 2001 } \\
\text { (adequação ao SGA). }\end{array}$ \\
\hline
\end{tabular}

\subsection{Melhoria contínua do SGA}

A USEXA utiliza o ciclo PDCA, para estruturação da melhoria contínua do Sistema de Gestão Ambiental. A USEXA também se utiliza do levantamento das não conformidades, das auditorias internas e reuniões de análise crítica como formas de atingir esta melhoria, conforme os Procedimentos $n^{\circ}$ PR-CTMSP-NCF01 (Controle de não conformidades, 2012); PR-CTMSP-AUD-01 (Execução de Auditorias Internas da Qualidade), PR-CTMSP-ADM-01 (Análise crítica do Sistema da Qualidade).

\subsection{Histórico de revisões}

\begin{tabular}{|c|c|l|}
\hline REVISÃO & DATA & \multicolumn{1}{c|}{ ALTERAÇÃo } \\
\hline 000 & $07 / 12$ & Emissão inicial \\
\hline
\end{tabular}




\section{REFERÊNCIA BIBLIOGRÁFICA}

ASSOCIAÇÃO BRASILEIRA DE INÚSTRIA QUÍMICA - ABIQUIM. Programa de Atuação Responsável. Disponível em: <http://www.abiquim.org.br>. Acesso em Nov. 1998. In: DONAIRE, D. Gestão Ambiental na empresa. $2^{a}$ Edição. São Paulo: Atlas, 1999. 169 p.

AGÊNCIA NACIONAL DE ENERGIA ELÉTRICA - ANEEL. Parte III - Fontes não renováveis: Energia Nuclear. Disponível em: http://www.aneel.gov.br/arquivos/PDF/atlas par3 cap8.pdf. Acesso em: 18 set. 2012.

AMERICAN SOCIETY FOR TESTING AND MATERIALS - ASTM. Standard methods for chemical, mass spectrometric, and spectrochemical analysis of nuclear-grade uranium dioxide powders and pellets, ASTM, 1980 (C69680). In: ULRICH, J. C. Determinação de impurezas em compostos de urânio por meio da técnica de espectrometria de massas de alta resolução com fonte de plasma indutivo (HR-ICPMS). 2001. Dissertação (Mestrado) - Instituto de Pesquisas Energéticas e Nucleares. São Paulo.

AQUINO, A. R.; SOARES, W.A; VIEIRA, M.M.F. Energia nuclear como cultura: um processo prático para preparação dos agentes desta transformação. Revista Brasileira de Pesquisa e Desenvolvimento. São Paulo, v. 10, n. 2, ago. de 2008.

AQUINO, A.R. Apostila do curso de fundamentos de tecnologia nuclear. São Paulo: Instituto de Pesquisas Energéticas e Nucleares. 2009.

ASSOCIAÇÃO BRASILEIRA DE NORMAS TÉCNICAS - ABNT. Requisitos gerais para a competência de laboratórios de ensaio e calibração, ABNT, 2005a (ABNT NBR ISO/IEC 17025:2005).

ASSOCIAÇÃO BRASILEIRA DE NORMAS TÉCNICAS - ABNT. Sistemas de gestão ambiental -Requisitos com orientação para uso. Rio de Janeiro: ABNT, 2004 (NBR ISO 14001).

ASSOCIAÇÃO BRASILEIRA DE NORMAS TÉCNICAS - ABNT. Sistemas de gestão ambiental - Diretrizes gerais sobre princípios, sistemas e técnicas de apoio. Rio de Janeiro: ABNT, 2005 (NBR ISO 14004).

ASSOCIAÇÃO BRASILEIRA DE NORMAS TÉCNICAS - ABNT. Diretrizes para auditoria de sistemas de gestão, ABNT, 2012 (ABNT NBR ISO 19011:2012).

BACKER, P. Gestão Ambiental: a administração verde. In: DONAIRE, D. Gestão Ambiental na empresa. $2^{a}$ Edição. São Paulo: Atlas, 1999. 169 p.

BARBIERI, J.C. Gestão Ambiental Empresarial: conceitos, modelos e instrumentos. $2^{a}$ Edição. São Paulo: Saraiva, 2004. 382 p. 
BENELLI, S. J. A cultura psicológica no mercado de bens de saúde mental contemporâneo. Estud. psicol. (Campinas), Campinas, v. 26, n. 4, dez. 2009 Disponível

em $<$ http://www.scielo.br/scielo.php?script=sci arttext\&pid=S0103166X2009000400012 \&lng=pt\&nrm=iso>. Acesso em: 18 jul. 2012.

BRASIL. Decreto Federal $n^{\circ}$ 530, de 20 de maio de 1992. Cria a Floresta Nacional de Ipanema. Diário Oficial da União, Brasília, DF. Disponível em: <http://www.jusbrasil.com.br/legislacao/113517/decreto-530-92>. Acesso em: 11 set. 2012.

BRASIL. Decreto $n^{\circ}$ 4.281, de 25 de junho de 2002. Regulamenta a Lei no 9.795, de 27 de abril de 1999, que institui a Política Nacional de Educação Ambiental, e dá outras providências. Diário Oficial da União, Brasília, 26 de jun. 2002.

BRASIL. Decreto $\mathrm{n}^{\circ} 5.025$, de 30 de março de 2004. Regulamenta o inciso I e os $\S 1^{\circ}, 2^{\circ}, 3^{\circ}, 4^{\circ}$ e $5^{\circ}$ do art. $3^{\circ}$ da Lei $n^{\circ} 10.438$, de 26 de abril de 2002 , no que dispõem sobre o Programa de Incentivo às Fontes Alternativas de Energia Elétrica - PROINFA, primeira etapa, e dá outras providências. Diário Oficial da União, Brasília, DF, v.141, n.62, p.1, 31 de mar. 2004. Seção 1

BRASIL. Decreto $n^{\circ}$ 93.439, de 17 de Outubro de 1986. Cria a Coordenadoria para Projetos Especiais e dá outras providências. Diário Oficial da União. Brasília, DF, p. 15730, 20 de out. de 1986. Seção 1

BRASIL. Decreto-lei $\mathrm{n}^{\circ}$ 1.809, de 07 de outubro de 1980. Institui o Sistema de Proteção ao Programa Nuclear Brasileiro, e dá outras providências. Diário Oficial da União, Brasília, DF, p. 20073, 08 de out. 1980. Seção 1

BRASIL. Lei $n^{\circ}$ 9.605, de 12 de fevereiro de 1998. Dispõe sobre as sanções penais e administrativas derivadas de condutas e atividades lesivas ao meio ambiente, e dá outras providências. Diário Oficial da União, Brasília, DF, p. 1, 13 de fev. 1998. Seção 1

BRASIL. Lei no 6.938, de 31 de agosto de 1981. Dispõe sobre a Política Nacional do Meio Ambiente, seus fins e mecanismos de formulação e aplicação, e dá outras providências. Diário Oficial da União, Brasília, 02 de set. 1981.

BRASIL. Lei $\mathrm{n}^{0}$ 9.985, de 18 de julho de 2000. Regulamenta o art. 225, § $1^{\circ}$, incisos I, II, III e VII da Constituição Federal, institui o Sistema Nacional de Unidades de Conservação da Natureza e dá outras providências. Diário Oficial da União, Brasília, DF. Disponível em: <http://www.planalto.gov.br/ccivil 03/leis/L9985.htm>. Acesso em: 11 set. 2012.

CAMARGO, M. Fundamentos da ética geral e profissional. Petrópolis: Vozes, 1999. In: DERETTE, L. D. O papel da ética na cultura organizacional estudo de caso. 2011. Monografia (MBA empresarial) - INPG - Instituto Nacional de Pós-Graduação. Joinville, SC. Disponível em: < 
http://www.eticaempresarial.com.br/imagens arquivos/artigos/File/Monografias/ O\%20PAPEL\%20DA\%20TICA\%20NA\%20CULTURA\%20ORGANIZACIONAL\% 20-\%20ESTUDO\%20DE\%20CASO.pdf.> Acesso em: 14 ago. 2012.

CENTRO TECNOLÓGICO DA MARINHA EM SÃO PAULO - CTMSP. Centro Experimental Aramar - CEA. Relatório de Impacto Ambiental - RIMA. Multiservice Engenharia. Revisão Final. Setembro 1997.

CENTRO TECNOLÓGICO DA MARINHA EM SÃO PAULO - CTMSP. Relatório Preliminar de Análise de Segurança da USEXA. CTMSP, 2001.

CENTRO TECNOLÓGICO DA MARINHA EM SÃO PAULO - CTMSP. Procedimento $n^{\circ}$ PR-CTMSP-TRE-01 - Treinamento de pessoal. CTMSP, São Paulo, SP, 2001a (Acesso restrito).

CENTRO TECNOLÓGICO DA MARINHA EM SÃO PAULO - CTMSP. Procedimento $n^{\circ}$ PR-CTMSP-SGA-01 - Identificação de aspectos e impactos ambientais, São Paulo, SP, 2003 (Acesso restrito).

CENTRO TECNOLÓGICO DA MARINHA EM SÃO PAULO - CTMSP. Procedimento $n^{\circ}$ PR-CTMSP-SGA-02_001 - Avaliação dos impactos ambientais. CTMSP, São Paulo, SP, 2003a (Acesso restrito).

CENTRO TECNOLÓGICO DA MARINHA EM SÃO PAULO - CTMSP. Procedimento $n^{\circ}$ PR-CTMSP-SGA-03 - Identificação de requisitos legais, São Paulo, SP, 2004 (Acesso restrito).

CENTRO TECNOLÓGICO DA MARINHA EM SÃO PAULO - CTMSP. Instrução Detalhada $n^{\circ}$ ID-CTMSP-SGA-01.001 - Coleta seletiva de resíduos recicláveis, São Paulo, SP. 2007 (Acesso restrito).

CENTRO TECNOLÓGICO DA MARINHA EM SÃO PAULO - CTMSP. Ordem Interna $n^{\circ}$ 70-07 - Coleta Seletiva de Resíduos Recicláveis, CTMSP, São Paulo, SP, 2007a (Acesso restrito).

CENTRO TECNOLÓGICO DA MARINHA EM SÃO PAULO - CTMSP. Procedimento $n^{\circ}$ PR-CTMSP-ACP-01 - Ação corretiva e ação preventiva, São Paulo, SP, 2008 (Acesso restrito).

CENTRO TECNOLÓGICO DA MARINHA EM SÃO PAULO - CTMSP. Ciclo do Combustível Nuclear. Disponível em: $<$ http://www.mar.mil.br/ctmsp/ciclo combustivel.html.>. Acesso em: 26 nov. 2011.

CENTRO TECNOLÓGICO DA MARINHA EM SÃO PAULO - CTMSP. Conheça o CTMSP, CTMSP, 2011a. Disponível em: <www.mar.mil.br/ctmsp/conheca centro.html. $>$. Acesso em: 26 nov. 2011. 
CENTRO TECNOLÓGICO DA MARINHA EM SÃO PAULO - CTMSP. Instrução Detalhada $n^{\circ}$ ID-C1099-PRE-01.001 - Combate a incêndios na USEXA, São Paulo, SP, 2011b (Acesso restrito).

CENTRO TECNOLÓGICO DA MARINHA EM SÃO PAULO - CTMSP. Instrução Detalhada $n^{\circ}$ ID-C1099-PRE-01.002 - Combate a vazamentos de gases perigosos na USEXA, São Paulo, SP, 2011c (Acesso restrito).

CENTRO TECNOLÓGICO DA MARINHA EM SÃO PAULO - CTMSP. Instrução Detalhada $n^{\circ}$ ID-C1099-PRE-01.003 - Combate a vazamentos de líquidos contendo materiais radioativos e/ou perigosos na USEXA, São Paulo, SP, 2011d (Acesso restrito).

CENTRO TECNOLÓGICO DA MARINHA EM SÃO PAULO. Instrução Detalhada $n^{\circ}$ ID-A2410-TRE-01.001 - Qualificação de pessoal do Departamento de Garantia da Qualidade, São Paulo, SP, 2011e (Acesso restrito).

CENTRO TECNOLÓGICO DA MARINHA EM SÃO PAULO. Laboratório Radioecológico - LARE, CTMSP, 2011f. Disponível em: <https://www.mar.mil.br/ctmsp/lare.html>. Acesso em: 26 dez. 2011.

CENTRO TECNOLÓGICO DA MARINHA EM SÃO PAULO. Procedimento $\boldsymbol{n}^{\circ}$ PR-CTMSP-NCF - Controle de não-conformidades, CTMSP, São Paulo, SP, 2012 (Acesso restrito).

CONFEDERAÇÃO NACIONAL DAS INDÚSTRIAS - CNI. Energia. Disponível em: $<$ http://www.cni.org.br/portal/data/pages/FF808081272B58C0012730BE3A077C B5.htm>. Acesso em: 06 set. 2012.

CONSELHO NACIONAL DO MEIO AMBIENTE - CONAMA. Resolução $n^{\circ} 1$, de 23.01.1986, Disciplina o Estudo de Impacto Ambiental - EIA e o Relatório de Impacto Ambiental - RIMA. Exigências, conteúdo, elaboração, responsabilidades, audiência pública. Diário Oficial da União, 07 de mar. 1986.

CONSELHO NACIONAL DO MEIO AMBIENTE - CONAMA. Resolução n 237, de 19.12.1997. Dispõe sobre licenciamento ambiental; competências da União, Estados e Municípios; listagem de atividades sujeitas ao licenciamento; Estudos Ambientais, Estudo de Impacto Ambiental e Relatório de Impacto Ambiental. Diário Oficial da União, 22 de dez. 1997.

CONSELHO NACIONAL DO MEIO AMBIENTE - CONAMA. Resolução n 357, de 17.05.2005 (Alterada pela Resolução $n^{\circ} 410 / 2009$ e pela 430/2011). Dispõe sobre a classificação dos corpos de água e diretrizes ambientais para o seu enquadramento, bem como estabelece as condições e padrões de lançamento de efluentes, e dá outras providências. Diário Oficial da União, 18 de mar. 2005.

CORRAL-VERDUGO, V.; PINHEIRO, J.Q. Condições para o estudo do comportamento pró-ambiental. Estudos de psicologia, Natal, v.4, n.1, 1999. 
Disponível em: <http://www.scielo.br/pdf/epsic/v4n1/a02v04n1.pdf>. Acesso em: 11 jun. 2012.

DEMING, W. E. Qualidade: A Revolução da Administração. Rio de Janeiro: Marques Saraiva, 1990.

DERETTE, L. D. O papel da ética na cultura organizacional - estudo de caso. 2011. Monografia (MBA empresarial) (CTMSP, 2012) - INPG - Instituto Nacional de Pós-Graduação. Joinville, SC. Disponível em: $<$ http://www.eticaempresarial.com.br/imagens arquivos/artigos/File/Monografias/ O\%20PAPEL\%20DA\%20TICA\%20NA\%20CULTURA\%20ORGANIZACIONAL\% 20-\%20ESTUDO\%20DE\%20CASO.pdf>. Acesso em: 14 ago. 2012.

DIRETORIA DE PORTOS E COSTAS DA MARINHA DO BRASIL - DPC. Sistema de Gestão Ambiental nas organizações militares de terra. Rio de Janeiro: DPC, $2003 \quad$ (NORTAM $n^{\circ} \quad$ 2). Disponível em: <http://www.dpc.mb/Nortam/nta 02/nortam02.pdf>. Acesso em: 14 ago. 2012.

DONAIRE, D. Gestão Ambiental na empresa. $2^{a}$ Edição. São Paulo: Atlas, 1999. $169 \mathrm{p}$.

ELETRONUCLEAR. Dados operacionais. Disponível em: <http://www.eletronuclear. gov.br/Home.aspx>. Acesso em: 26 dez. 2011.

GILBERT, M.J. ISO 14.001/BS7750: Sistema de Gerenciamento Ambiental. $1^{\text {a }}$ Edição. São Paulo: IMAM, 1995. 253 p.

GONÇALVES, O. D. Palestra: Programa Nuclear Brasileiro: passado, presente $\quad$ e futuro. Disponível em: $<$ http://www.senado.gov.br/comissoes/cct/ap/AP20080702 ProdEnergiaNuclea

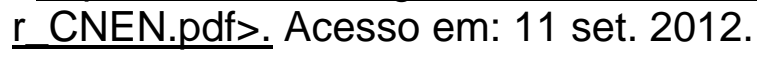

INSTITUTO BRASILEIRO DO MEIO AMBIENTE E DOS RECURSOS NATURAIS RENOVÁVEIS - IBAMA. Instrução Normativa $\mathrm{n}^{\circ}$ 2, de 27 de março de 2012. Estabelece as bases técnicas para programa de educação ambiental apresentados como medidas mitigadoras ou compensatórias, em cumprimento às condicionantes das licenças ambientais emitidas pelo IBAMA. Diário Oficial da União, Brasília, DF de 29 de mar. 2012, nº 62, pág. 130. Seção 1

INTERNATIONAL ATOMIC ENERGY AGENCY - IAEA. Safety of Conversion Facilities and Uranium Enrichment Facilities. Vienna: 2010 (SSG-5), IAEA, 2012. Disponível em: http://www-pub.iaea.org/MTCD/ publications/PDF/Pub1404 web.pdf . Acesso em: 14 ago. 2012.

KOMATSU, C. N. Diretrizes para avaliação do gasto ambiental no ciclo do combustível nuclear. 2008, 89 p. Dissertação (Mestrado) - Instituto de Pesquisas Energéticas e Nucleares, Universidade de São Paulo, São Paulo. 
MARIN, M.P.A. Análise de perigos em uma instalação de produção de hexafluoreto de urânio. 1999. Dissertação (Mestrado) - Instituto de Pesquisas Energéticas e Nucleares. In: OLIVEIRA, D.P. Estudo da correlação entre normas da Agência Internacional de Energia Atômica e de mercado sobre sistema de gestão aplicável à operação de planta de conversão de UF 2008. Dissertação (Mestrado) - Instituto de Pesquisas Energéticas e Nucleares. São Paulo.

MARIN, M.P.A. Análise de riscos e avaliação de impacto ambiental em uma instalação de processamento químico. 2005. Tese (Doutorado) - Faculdade de Engenharia Química. Campinas, São Paulo. Disponível em: $<$ http://www.bibliotecadigital.unicamp.br/document/?code=vtls000374660\&fd=y. $>$ Acesso em: 14 ago. 2012.

MARINHA DO BRASIL - MB. Programa Nuclear da Marinha. Disponível em: $<$ http://www.mar.mil.br/menu v/ccsm/temas relevantes/programa nuclear mb.h $\underline{\mathrm{tm}}>$. Acesso em: $26 \mathrm{dez} .2011$.

MATTIOLO, S. R; AQUINO, A. R. Implementation of the environmental management system in nuclear fuel cycle: A case study of the USEXA - CTMSP. In: INTERNATIONAL NUCLEAR ATLANTIC CONFERENCE, 2009, Anais. Rio de Janeiro: Aben, 2009. p. 50 - 55.

MATTIOLO, S.R.; AQUINO, A.R.; ARADI, T. C. Proposition of the filter of significance in the evaluation of environmental impacts in accordance with the enterprise location. In: INTERNATIONAL NUCLEAR ATLANTIC CONFERENCE, 2011, Anais, Belo Horizonte: Aben, 2011. p. 0 - 08.

MATTIOLO, S.R.; BOEMER, V.A.; AQUINO, A.R. Diretrizes modernas de educação ambiental e psicologia ambiental na fase de conscientização e treinamento de Sistemas de Gestão Ambiental. Revista Brasileira de Pesquisa e Desenvolvimento, São Paulo, v. 11, n. 3, p. 79-84, 2009.

MAXIMIANO, A.C.A. Teoria geral da administração: da revolução urbana à revolução digital. 4a Edição. São Paulo: Editora Atlas S.A., 2004.

MILARÉ, S.A. Investimento com Retorno Garantido. Revista T\&D -Inteligência Corporativa, 12 (132), 20-22. 2004 In: MILARE, Sueli Aparecida; YOSHIDA, Elisa Medici Pizão. Intervenção breve em organizações: mudança em coaching de executivos. Psicol. estud., Maringá, v. 14, n. 4, dez. 2009 . Disponível em $\quad<$ http://www.scielo.br/scielo.php?script=sciarttext\&pid=S1413-

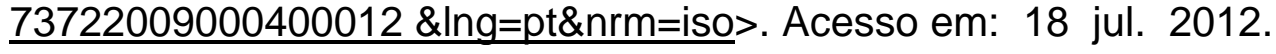

MINISTÉRIO DA EDUCAÇÃO E CULTURA - MEC. Tratado de Educação Ambiental para Sociedades Sustentáveis e Responsabilidade Global: TEASS. MEC, 2012a. Disponível em: $<$ http://portal.mec.gov.br/secad/arquivos/pdf/educacaoambiental/ tratado.pdf> . Acesso em: 30 maio 2012. 
MINISTÉRIO DA EDUCAÇÃO E CULTURA - MEC. Um pouco da História da Educação Ambiental. Disponível em: <http://portal.mec.gov.br/secad/arquivos/pdf/ educacaoambiental/historia.pdf>. Acesso em: 30 maio 2012.

MINISTÉRIO DO MEIO AMBIENTE - MMA. Capítulo 36 da Agenda 21. Disponível em: <http://www.mma.gov.br/educacao-ambiental/politica-deeducacao-ambiental/ documentos-referenciais/item/8067>. Acesso em: 30 maio 2012.

MOURA, L. A. A. de. Qualidade e gestão ambiental: Sugestões para implantação das normas ISO 14.000 nas empresas. 3. ed. São Paulo: Juarez de Oliveira, 2002. 331 p.

MOURA, L. A. A. Proposta de implantação de um sistema de gestão ambiental no laboratório de rejeitos radioativos do IPEN-SP. 2008. 149 p. Dissertação (Mestrado) - - Instituto de Pesquisas Energéticas e Nucleares, Universidade de São Paulo, São Paulo, 2008.

OLIVEIRA, D. P. Estudo da correlação entre normas da agência internacional de energia atômica e de mercado sobre sistema de gestão aplicável à operação de planta de conversão de UF6. 2008. 229 p. Dissertação (Mestrado) - Instituto de Pesquisas Energéticas e Nucleares, Universidade de São Paulo, São Paulo, 2008.

POL, Eric A gestão ambiental, novo desafio para a psicologia do desenvolvimento sustentável. Estudos de psicologia, Natal, v.8, n.2, 2003. Disponível em:

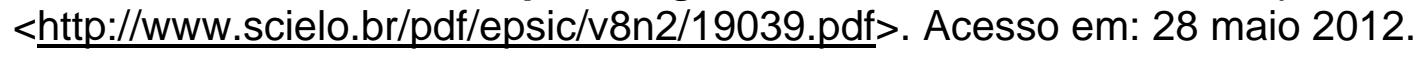

PORTAL BRASIL. Matriz energética. Disponível em: <http://www.brasil.gov.br/cop/panorama/o-que-o-brasil-esta-fazendo/matrizenergetica $>$. Acesso em: 06 set. 2012.

PROGRAMA DAS NAÇÕES UNIDAS PARA O DESENVOLVIMENTO - PNUD. Os Objetivos de Desenvolvimento do Milênio. Disponível em: <http://www.pnud.org.br/ODM.aspx>. Acesso em: 24 jul. 2012.

PROGRAMA DE INCENTIVO ÀS FONTES ALTERNATIVAS DE ENERGIA ELÉTRICA - $\quad$ PROINFA. Programas. Disponível em:<http://www.mme.gov.br/programas/proinfa/>. Acesso em: 06 set. 2012.

PROGRAMA NACIONAL DE EDUCAÇÃO AMBIENTAL - PRONEA. Documento consolidado. Brasília, $3^{a}$ edição, 2005. Disponível em: $<$ http://portal.mec.gov.br/secad/arquivos/pdf/educacaoambiental/pronea3.pdf>. Acesso em: 14 ago. 2012.

REIS, L. B.; FADIGAS, E.A.A.; CARVALHO, C.E. Energia, recursos naturais e a prática do desenvolvimento sustentável. $1^{\circ}$ Edição. Barueri, SP: Manole, 2005. 415 p. 
ROBBINS, S. P. Comportamento Organizacional. Tradução técnica: Reynaldo Marcondes. - 9a edição - São Paulo: Prentice Hall, 2002.

SOCIEDADE BRASILEIRA DE NEUROLINGUISTICA - SBPNL. O que é PNL? Disponível em: <http://pnl.com.br/siteSobre/home>. Acesso em: 23 jul. 2012.

SOLEDADE, M. das G. M.; et al. ISO 14000 e a gestão ambiental: uma reflexão das práticas ambientais corporativas. 2007. Curitiba: Encontro Nacional sobre Gestão Empresarial e meio ambiente - ENGEMA. Disponível em: $<$ http://xa.yimg.com/kq/groups/24052049/440923092/name/TEXTO+DE+ CI\%C3\%8ANCIAS+DO+AMBIENTE.pdf. Acesso em: 14 ago. 2012

TASSARA, E.; et al. (org.). Psicologia e ambiente. São Paulo: Educ, 2004, 408p. In MATTIOLO, S.R.; BOEMER, V.A.; AQUINO, A.R. Diretrizes modernas de educação e psicologia ambiental na fase de conscientização e treinamento de sistemas de gestão ambiental. Rev. Bras. Pesq. Des. - Vol. $11 n^{\circ} 3$-Nov. 2009, São Paulo, SP.

TOLMASQUIM, M. T.; GUERREIRO, A.; GORINI, R. Matriz energética brasileira: uma prospectiva. Novos Estudos. Nov. 2007. Disponível em: $<$ http://www.scielo.br /scielo.php?script=sci arttext\&pid= S010133002007000300003>. Acesso em: 06 set. 2012.

UNIVERSIDADE FEDERAL DO RIO DE JANEIRO - UFRJ. II Semana de Engenharia Nuclear - Conversão. Disponível em: $<$ http://www.nuclear.ufrj.br/semana/pdf/Joao Descricao Conversao CCOMC.pdf>. Acesso em 18 set 2012.

WINTER, G. Gestão e ambiente: modelo prático de integração empresarial. In: DONAIRE, D. Gestão Ambiental na empresa. 2a Edição. São Paulo: Atlas, 1999. 169 p. 